\title{
The Tell-Rif orogenic system (Morocco, Algeria, Tunisia) and the structural heritage of the southern Tethys margin
}

\author{
Rémi Leprêtre ${ }^{1,2, *}$, Dominique Frizon de Lamotte $^{1}$, Violaine Combier ${ }^{3}$, Oriol Gimeno-Vives ${ }^{1}$, \\ Geoffroy Mohn ${ }^{1}$ and Rémi Eschard ${ }^{3}$ \\ ${ }^{1}$ Université de Cergy-Pontoise, Département Géosciences et Environnement (GEC), 1 rue Descartes, 95000 Neuville/Oise Cedex, France \\ 2 Sorbonne Université, CNRS-INSU, Institut des Sciences de la Terre Paris, ISTeP UMR 7193, 75005 Paris, France \\ 3 Total-EP, 2 place Jean Millier, 92078 Courbevoie La Défense, France
}

Received: 30 January 2018 / Accepted: 15 June 2018

\begin{abstract}
The Tell-Rif (Tell in Algeria and Tunisia; Rif in Morocco) is the orogenic system fringing to the south the West Mediterranean basins. This system comprises three major tectonic-palaeogeographic zones from north to south: (1) the internal zones (AlKaPeCa for Alboran, Kabylies, Peloritan, Calabria) originating from the former northern European margin of the Maghrebian Tethys, (2) the "Flyschs zone" regarded as the former cover of the oceanic domain and (3) the external zones, forming the former southern Maghrebian Tethys margin more or less inverted. The Tell-Rif is interpreted as the direct result of the progressive closure of the Maghrebian Tethys until the collision between AlKaPeCa and Africa and, subsequently, the propagation of the deformation within Africa. This gives a consistent explanation for the offshore Neogene geodynamics and most authors share this simple scenario. Nevertheless, the current geodynamic models do not completely integrate the Tell-Rif geology. Based on the analysis of surface and sub-surface data, we propose a reappraisal of its present-day geometry in terms of geodynamic evolution. We highlight its non-cylindrical nature resulting from both the Mesozoic inheritance and the conditions of the tectonic inversion. During the Early Jurassic, we emphasize the development of NE-SW basins preceding the establishment of an E-W transform corridor connecting the Central Atlantic Ocean with the Ligurian Tethys. The Maghrebian Tethys developed just after, as the result of the Late Jurassic-Early Cretaceous left-lateral spreading between Africa and Iberia. By the Late Cretaceous, the occurrence of several tectonic events is related to the progressive convergence convergence between the two continents. A major pre-Oligocene (pre-35 Ma) compressional event is recorded in the Tell-Rif system. The existence of HP-LT metamorphic rocks associated with fragments of mantle in the External Metamorphic Massifs of the Eastern Rif and Western Tell shows that, at that time, the western part of the North-African margin was involved in a subduction below a deep basin belonging to the Maghrebian Tethys. At the same time, the closure of the West Ligurian Tethys through east-verging subduction led to a shift of the subduction, which jumped to the other side of AlKaPeCa involving both East Ligurian and Maghrebian Tethys. Slab rollback led to the development of the Oligo-Miocene back-arc basins of the West-Mediterranean, reworking the previous West Ligurian Tethys suture. The docking of AlKaPeCa against Africa occurred during the Late Burdigalian (17 Ma). Subsequently, the slab tearing triggered westward and eastward lateral movements that are responsible for the formation of the Gibraltar and Tyrrhenian Arcs respectively. The exhumation of the External Metamorphic Massifs occurred through tectonic underplating during the westward translation of the Alboran Domain. It resulted in the formation of both foredeep and wedge-top basins younger and younger westward. The lack of these elements in the eastern part of the systems signs a different evolution dominated by frontal accretion. In the discussion, we precisely address the origin of the non-cylindrical behavior of the orogenic system and question the mechanisms explaining at large scale the phases of coupling/uncoupling between the major plates.
\end{abstract}

Keywords: Tell-Rif orogenic system (Algeria, Morocco, Tunisia) / Tethys / West Mediterranean / coupling vs decoupling / frontal accretion vs tectonic underplating

*Corresponding author: remi.lep@gmail.com 
Résumé - Le système orogénique tello-rifain (Maroc, Algérie, Tunisie) et le problème de l'héritage structural sur la marge sud téthysienne. Le Tell-Rif (Tell en Algérie et Tunisie; Rif au Maroc) est un système orogénique qui borde au sud les bassins ouest méditerranéens. Ce système comprend trois zones tectono-paléogéographiques principales, du Nord au Sud: (1) les zones internes (ou AlKaPeCa pour Alboran-Kabylies-Peloritain-Calabre) issues de l'ancienne marge septentrionale, côté Europe, de la Téthys Maghrébine, (2) le domaine des Flyschs, considéré comme la couverture sédimentaire de ce domaine océanique disparu et (3) les zones externes, représentant la marge sud téthysienne plus ou moins inversée. Dans le contexte de la formation des bassins de Méditerranée occidentale, le Tell-Rif résulterait directement de la fermeture progressive de la Téthys Maghrébine jusqu'à la collision entre AlKaPeCa et l'Afrique, puis, de la propagation dans la plaque Afrique vers le sud de cette déformation. Ce scénario, qui fournit une explication satisfaisante pour la géodynamique néogène, est approuvé par la majorité des auteurs. Cependant, ces modèles géodynamiques tiennent peu compte de la géologie tello-rifaine en se basant la plupart du temps sur l'arc bético-rifain et oubliant de fait l'ancienne marge téthysienne nord-africaine et les données sur les Kabylies. Sur la base de données de surface et de sub-surface, nous proposons une réévaluation de la géométrie actuelle du Tell-Rif au regard de son histoire géodynamique. Cette synthèse nous permet de souligner son important non-cylindrisme, qui résulte à la fois de l'héritage mésozoïque et des conditions de l'inversion. Au cours du Jurassique inférieur, nous insistons sur le développement de bassins d'orientations NE-SW antérieurs à la mise en place d'un grand couloir transformant qui relia l'Océan Atlantique Central à la Téthys Ligure. La Téthys Maghrébine s'est développée postérieurement, en réponse à l'ouverture en contexte de décrochement senestre de l'espace entre la plaque ibérique et l'Afrique au Jurassique supérieur-Crétacé inférieur. Lors du Crétacé supérieur, plusieurs événements tectoniques survinrent au cours du rapprochement Afrique-Europe. Un événement compressif majeur intervient avant l'Oligocène (anté-35 Ma). L'existence de roches métamorphiques de HP-BT associées à des fragments mantelliques dans les «Massifs Externes à Schistosités du Rif oriental et du Tell occidental montre en effet qu'à cette époque, la partie occidentale de la marge sud-téthysienne a été impliquée dans une subduction sous un bassin profond, appendice de la Téthys Maghrébine. En même temps, la disparition de la Téthys Ligure occidentale, dans une subduction à vergence vers l'est, a permis un saut de subduction du côté sud-est d'AlKaPeCa, pour finalement impliquer les Téthys Maghrébine et Ligure orientale. Le retrait du panneau plongeant d'abord vers le sud, puis vers l'ouest, permit la mise en place des bassins arrière-arc oligo-miocènes de Méditerranée occidentale réutilisant la suture de la Téthys Ligure précédemment fermée. L'arrimage du microcontinent AlKaPeCa contre l'Afrique se produit au Burdigalien supérieur (17 Ma). À sa suite, le panneau plongeant subit deux déchirements latéraux vers l'ouest et l'est, à l'origine des arcs de Gibraltar et Tyrrhénien, respectivement. L'exhumation des massifs externes à schistosité fut alors permise via un sous-plaquage tectonique lors du déplacement vers l'ouest du domaine d'Alboran. Ceci eut pour conséquence la formation d'une fosse d'avant-pays et de bassins supra-nappes de plus en plus jeunes vers l'ouest. Ces éléments n'existent pas à l'est et démontrent une évolution structurale différente, dominée par l'accrétion frontale. Dans la discussion, nous apportons des éléments précis sur l'origine du non-cylindrisme du système et sur les mécanismes qui pourraient expliquer à grande échelle les phases de couplage/ découplage entre les plaques tectoniques en jeu.

Mots clés : système orogénique tello-rifain (Maroc, Algérie, Tunisie) / Téthys / Méditerranée occidentale / couplage $v s$. découplage / accrétion frontale vs. sous-plaquage

\section{Introduction}

The West Mediterranean back-arc basins developed since the Oligocene in relation with the roll-back of the subduction of the Ligurian-Maghrebian Tethys ${ }^{1}$ (LMT) (Bouillin, 1986; Doglioni et al., 1999; Frizon de Lamotte et al., 2000; Gueguen et al., 1998; Jolivet and Faccenna, 2000; Jolivet et al., 2008; Lonergan and White, 1997; Malinverno and Ryan, 1986; Réhault et al., 1984; Vergés and Sàbat, 1999; Fig. 1). The net result of the roll-back was the stripping-off of the Alboran, Kabylie, Peloritan and Calabria (AlKaPeCa) domains from the European margin

\footnotetext{
${ }^{1}$ In our acceptation, the Ligurian Tethys is the southern part of the Alpine Tethys and the Maghrebian Tethys is the former oceanic connection between the Ligurian Tethys and Central Atlantic. We will see below that the Ligurian Tethys likely comprised two parallel branches.
}

(Alvarez, 1974; Bouillin, 1986). A two-steps scenario is currently considered for the formation of the West Mediterranean basins (Bouyahiaoui et al., 2015; Medaouri et al., 2014 and references therein). A first episode of NNW-SSE extension (Aïte and Gélard, 1997) occurred until the docking of AlKaPeCa blocks against $A$ frica, which following radiochronologic data on granites cross-cutting the African crust, occurred during the Lower Miocene before or at $17 \mathrm{Ma}$ (Abbassene et al., 2016; Aïssa et al., 1999; Chazot et al., 2017). A second episode of E-W extension is related to slab tearing, delamination and rapid translations westward, forming the Betic-Rif Arc (or Gibraltar Arc), and eastward, forming the Tyrrhenian Arc. This episode can be tracked in the tectono-sedimentary record from the Serravalian to the Tortonian from the western Tell to the central Rif (among others, Delteil, 1974; Guardia, 1975; Mattauer, 1958; Polvêche, 1960; Septfontaine, 1983).

The Tell-Rif (Tell in Algeria and Tunisia; Rif in Morocco) or Maghrebides is the orogenic system fringing the West 


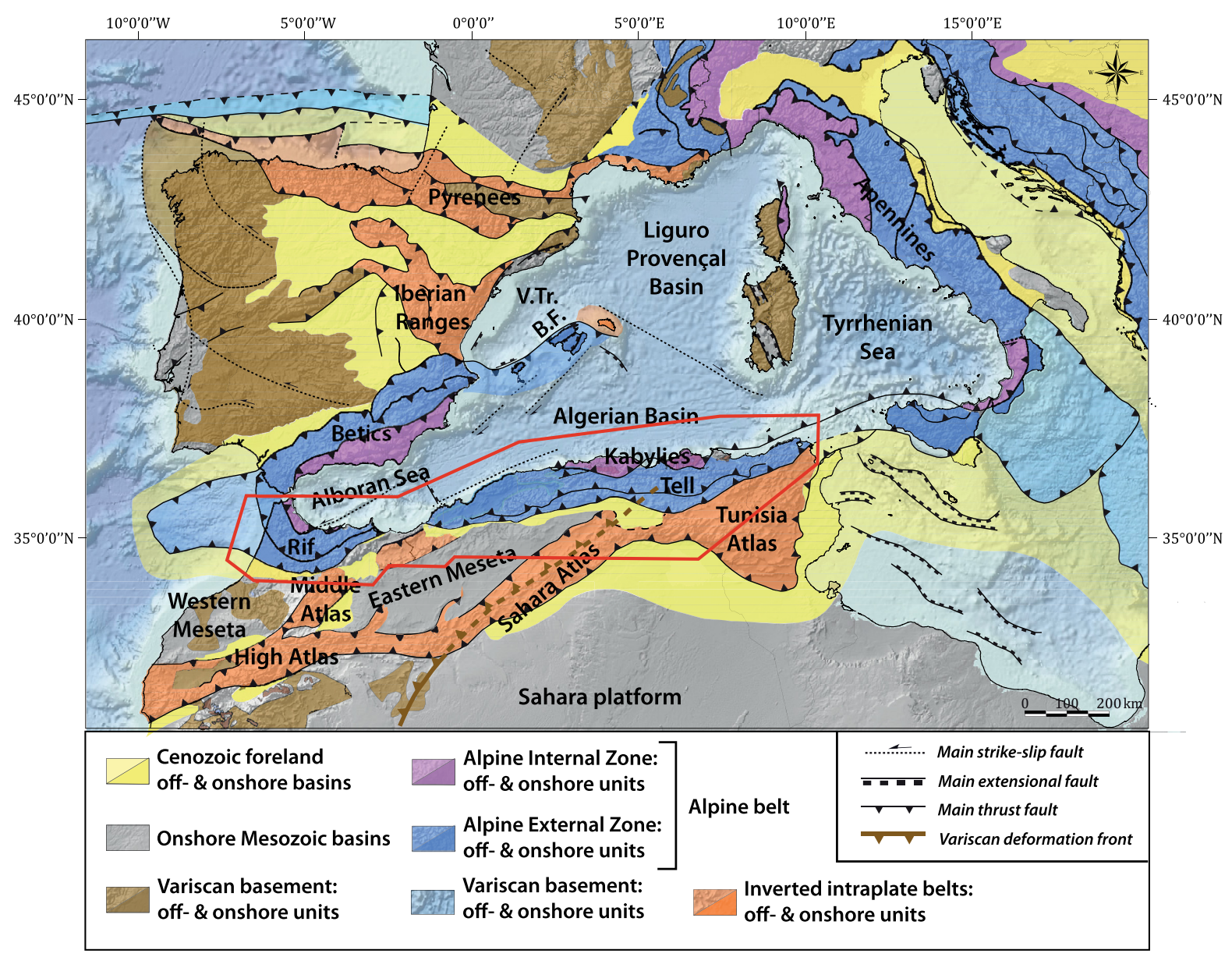

Fig. 1. Structural scheme of the Western Mediterranean region (after Etheve et al., 2016). West Mediterranean, Europe and North Africa structural features are shown, differenciating the Alpine and intracontinental belts, respectively. Location of the map of Figure 2 is given (red polygon). Note that the Variscan front is only drawn for Northwest Africa.

Mediterranean basins to the south (Durand-Delga, 1969; Wildi, 1983). This system comprises 3 major tectonic-palaeogeographic zones, i.e., from north to south: (1) the internal zones $(\mathrm{AlKaPeCa})$ originated from the former northern European margin of the LMT; (2) the "Flyschs zone" regarded as the former sedimentary cover of the LMT and (3) the external zones, the former North African passive margin of the LMT (Fig. 2).

In the geodynamic frame of the West Mediterranean basins formation, the Tell-Rif is interpreted as the direct result of the progressive closure of the LMT until the collision of $\mathrm{AlKaPeCa}$ with Africa at $17 \mathrm{Ma}$. Such a scenario gives a consistent explanation for the offshore geodynamics and is now shared by almost all the authors. Some discussions remain about the importance of the westward movements (i.e. the initial position of Alboran terrane [the "Al" of the AlKaPeCa system]) and their precise timing. The difference between reconstructions by Van Hinsbergen et al. (2014) and CrespoBlanc et al. (2016) are considerable in terms of westward migration of the Alboran domain but are end-members of a single model.

This consensus has been recently broken by Vergés and Fernàndez (2012) followed by Casciello et al. (2015), who propose a completely different model. Their model suggests that Alboran was initially (i.e. during the Mesozoic) located along the African margin and consequently separated from the Kabylie, which, together with the Calabrian and Peloritan terranes, were on the European side of the Maghrebian Tethys. This provocative proposition is interesting but disregards several geological evidences:

the strong palaeogeographic affinities between Alboran and the Kabylie during the whole Mesozoic, especially during Triassic time, these two domains being characterized by "Alpine" facies contrasting with the "Germanic" facies which characterize both African and Iberian margins (Bouillin, 1986; Durand-Delga, 1969);

offshore data (Booth-Rea et al., 2007; Medaouri et al., 2014), suggesting rather WSW than NW movements of the Alboran Domain;

seismic data showing that Kabylie-like terranes can be currently followed offshore up to the Oran meridian (Domzig et al., 2006), i.e. in the assigned root zone of Alboran in the Vergés and Fernàndez (2012) model.

For these reasons, we do not retain this scenario and the present paper follows the frame of classical models consider- 
R. Leprêtre et al:: BSGF 2018, 189, 10

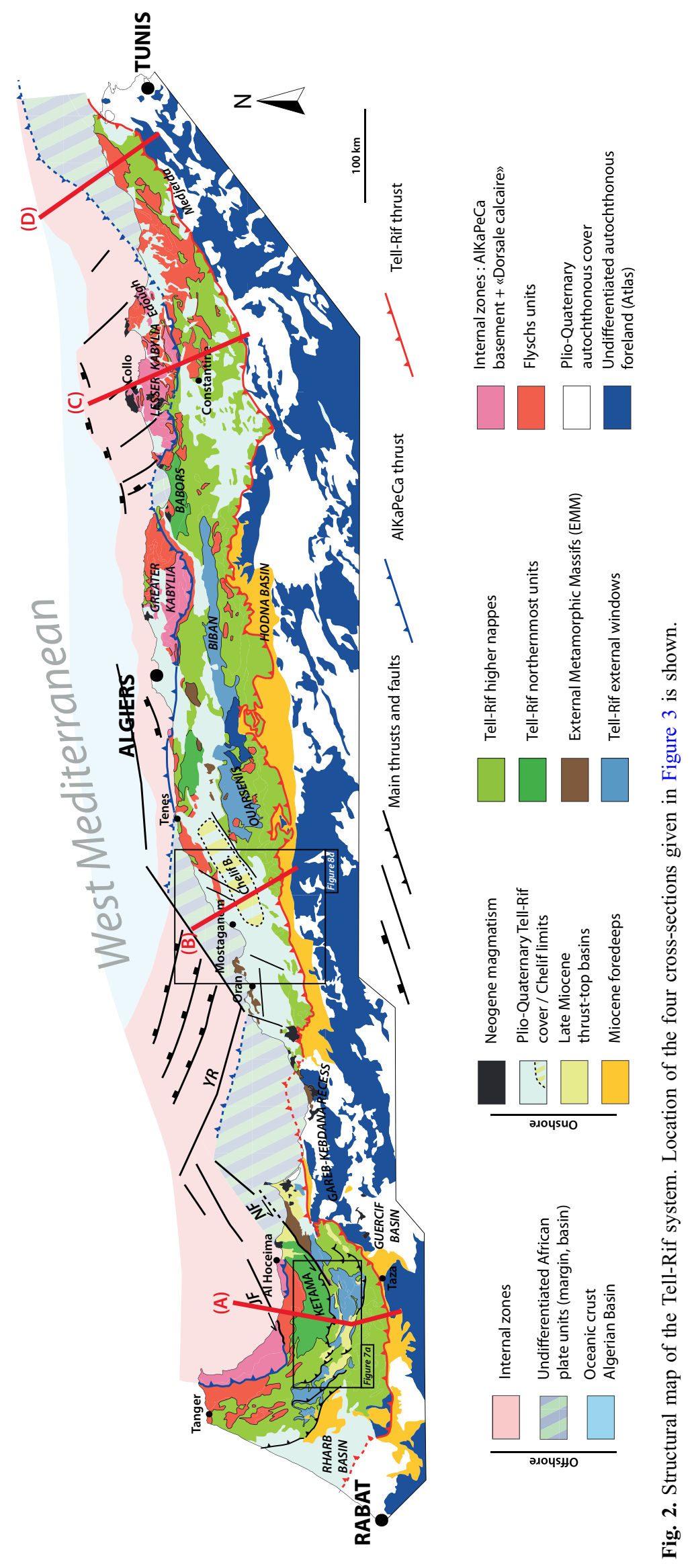

Page 4 of 35 
ing the European origin for all the AlKaPeCa domain. Nevertheless, these latter geodynamic models fail to integrate at least two major issues: they do not incorporate all recent geological developments in the Betics geology and forget partially or totally the Tell-Rif geology. We will not develop the Betics geology here. As a matter of fact, dealing with the Rif history for Mesozoic and Cenozoic times makes more sense in comparison with the evolution of the Tell, as they both belong to the South Tethys margin. The comparison between Rif and Betics is an important topic but mainly for the recent post-Early Miocene stages when Rif and Betics share several common events. For the sake of geological coherence since we consider the evolution of the South Tethys margin, we propose a renewed view of both the Tell and the Rif evolution, with a particular emphasis on the following points:

- the importance of the Paleozoic and early Mesozoic structural inheritance, which strongly influenced the southern Tethys margin geometry;

- the significance of pre-Late Oligocene (pre-30 Ma) compressional events not only in the Atlas System, where they are well established (see a review in Frizon de Lamotte et al., 2000, 2009, 2011), but also in the Tell-Rif system, where their effects were often ignored or minimized;

- the existence of high pressure-low temperature (HP-LT) metamorphic suite, typical of subduction zones, (Negro et al., 2007) associated with fragments of serpentinites in the Eastern Rif (Michard et al., 1992, 2007, 2014) and likely in the Western Tell (Fenet, 1975; Guardia, 1975; Michard et al., 2006, 2007). This suggests that the southern Maghrebian Tethys margin was involved in subduction. The metamorphic rocks are preserved in the so-called "Massifs Externes à schistosité" of the French authors (hereafter called External Metamorphic Massifs [EMM]), strung out over Eastern Rif and Western Tell (Fig. 2); - the presence of wide Miocene basins associated with the EMM and developed on top of the orogenic system in the Rif and western Tell (Fig. 2). Among these basins, the Chelif Basin occupies a large part of the western Tell in Algeria (Neurdin-Trescartes, 1992; Perrodon, 1957).

To address these topics, we will first examine the structure and geometry of the Tell-Rif system, emphasizing its noncylindrical character. Then, we will establish new and/or revised facts explaining the changes in the lateral organization of the orogenic system. On this basis, we will propose an updated set of palaeogeographical maps for the Cenozoic evolution of the West Mediterranean. Key geodynamics consequences of our review will be discussed at the end of this contribution.

\section{Geological setting - overall geometry of the Tell-Rif}

The Tell is a linear mountain belt striking E-W. By contrast, an important curvature exists in the Rif, which swings from E$\mathrm{W}$ in the eastern Rif to N-S in the western Rif (Fig. 1). This feature is the southern branch of the "Gibraltar Arc" or "BeticRif Arc" (Durand-Delga and Fontboté, 1980), which extends northward in the Betics where another $90^{\circ}$ apparent clockwise swing is observed. These are late-acquired Neogene features related to the Alboran motion and associated vertical axis rotations (e.g. Cifelli et al., 2016; Platt et al., 2013). The BeticRif belts thus defines a very arcuate orogenic system (Lonergan and White, 1997). The Tell also extends in Sicily towards the Apennines, with a "symmetrical" 90 anticlockwise swing within the Calabrian arc. In the literature, the Tell-Rif belt is presented as a cylindrical orogenic system with continuous palaeogeographic-palaeotectonic zones, namely the internal zones (AlKaPeCa), the Flyschs zone and the external zones (see the masterly synthesis of Wildi, 1983). However, these zones are not continuous and very important along strike variations occur in the external zones (Figs. 2 and 3). Relying on the available literature and new cross-sections along the belt, we will describe the first-order geometry of the system and its lateral variations from the internal zones toward the external ones in the following sections.

\subsection{The AlKaPeCa and Flyschs domains}

The internal zones of the Tell-Rif belt, shared with the Betics, belong to the AlKaPeCa domain, as defined by Bouillin (1986). AlKaPeCa is a continental domain with European affinities (Bouillin, 1986; Michard et al., 2002, 2006). Except from a dismembered Mesozoic to Eocene cover (the so-called "Dorsale Calcaire"), unconformably capped by upper Oligocene to lower Miocene clastics, it mainly shows Paleozoic rocks distributed into two major nappes complexes. They crop out in Lesser Kabylie (Bouillin, 1979; Bouillin and Perret, 1982; Caby and Hammor, 1992; Mahdjoub et al., 1997), Greater Kabylie (Saadallah and Caby, 1996) and Internal Rif (review in Michard et al., 2006). The upper nappe complex is poorly or non-metamorphic, only recording Variscan events. However, close to the basal contact with the lower nappe complex an Early Miocene metamorphic event widely overprinting also the lower nappe can be recognized (see Chalouan and Michard, 1990; Negro et al., 2006 for the Rif; Saadallah and Caby, 1996 for the Lesser Kabylie; among others Caby et al., 2001; Fernandez et al., 2016 for the Edough Massif). In contrast, the lower nappe (internal Rif: Sebtides; Greater Kabylie: Lower Unit; Lower Kabylie: Beni Ferguen nappe) shows a general higher grade and a clear polyphased history. It is separated from the upper nappe through an extensional shear zone. This lower nappe still records remnants of the Variscan events (e.g. Fernandez et al., 2016; Mahdjoub et al., 1997; Montel et al., 2000; Peucat and Bossière, 1981; Saadallah and Caby, 1996; Sánchez-Gómez et al., 1999; Zeck, 1999). However, it is mainly characterized by the signature of the Alpine events, ranging from HP-LT for the earliest events (Bruguier et al., 2017; Caby et al., 2014; Mahdjoub et al., 1997) to HT-LP for the most recent ones during Early to Middle Miocene (Fernandez et al., 2016; Michard et al., 2006; Platt et al., 2013; Rossetti et al., 2010 with references therein). The Edough massif presents a peculiar case. It has either been interpreted as an external or an internal massif (Bruguier et al., 2017; Caby et al., 2001; Caby et al., 2014; Hilly, 1962; Michard et al., 2006; Vila, 1970). This difficulty stems from the poorly defined contact between the external zones and the Edough massif. For Vila (1970), the Edough massif shows a 

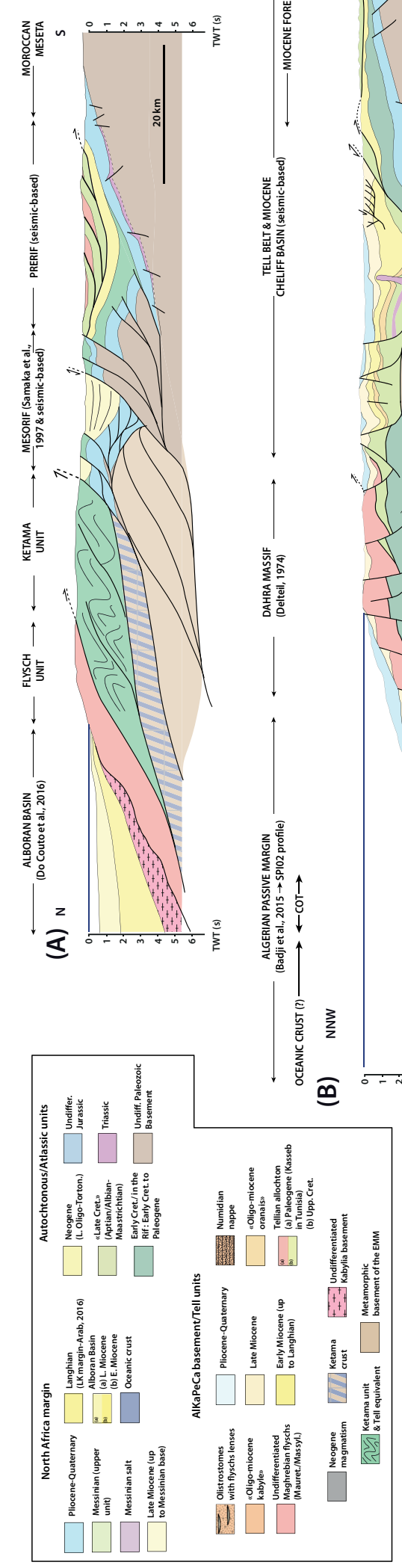

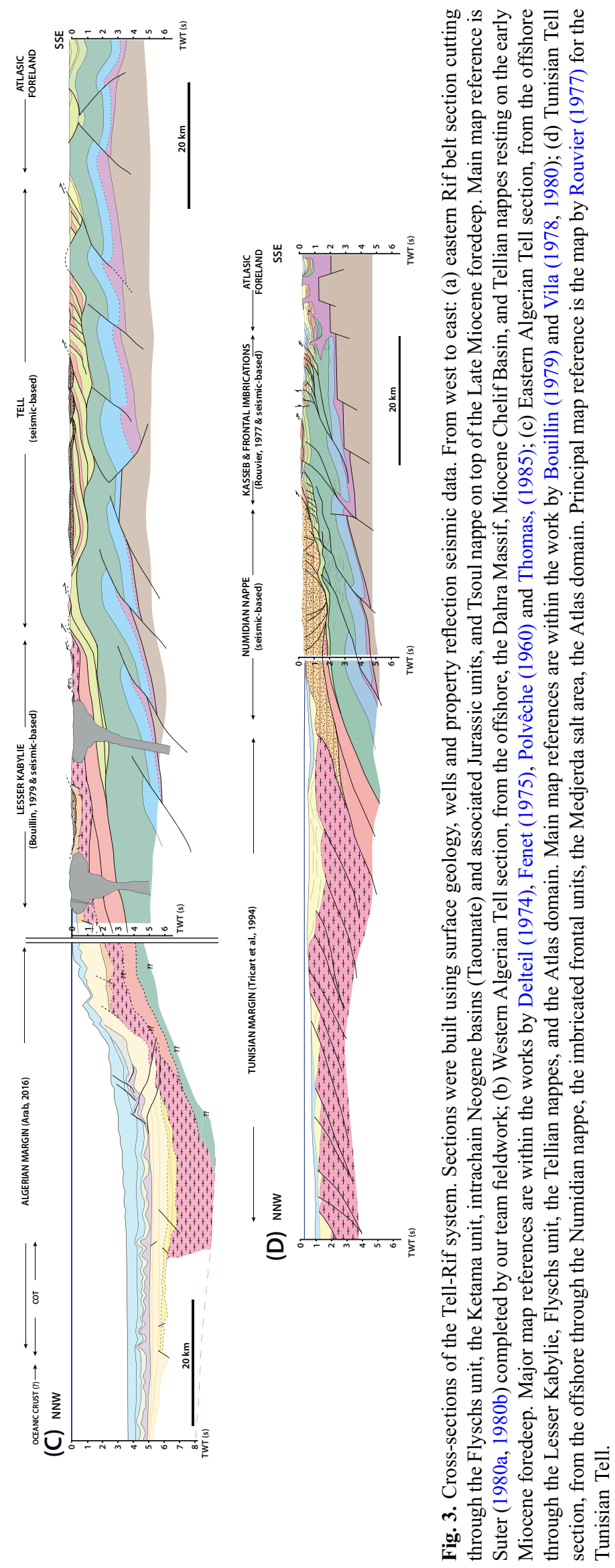


metamorphic cover belonging to the South Tethys margin. Caby et al. (2001) demonstrated that this contact is not a stratigraphical one but tectonic, still approving the external nature of the Edough Massif. They considered it to be an African metamorphic core complex, developed after the emplacement of the Tellian nappes (and following them, among others, Caby et al., 2014; Fernandez et al., 2016; Bruguier et al., 2017). Following Michard et al. (2006) on the basis of metamorphic data and Paleozoic remnants within the massif, it is considered as belonging to the internal zones rather than the external ones. The recent geochemical and Oligocene-Miocene dating results also converge more with an internal origin (Bruguier et al., 2017; Fernandez et al., 2016).

Sandwiched between AlKaPeCa and the external domain (Figs. 2 and 3), the Flyschs domain is consensually viewed as the former cover of the Maghrebian Tethys and partially of the East Ligurian Tethys (i.e. the "Bassin des Flyschs" of the French authors), separating Europe and Iberia from the African plate up to the Miocene (Bouillin et al., 1970; Durand-Delga and Fontboté, 1980; Guerrera and Martín-Martín, 2014 for a review). The flyschs are divided into two units, namely an internal "Mauretanian" unit, whose stratigraphic age spans from Jurassic to Late Miocene, and an external "Massylian" unit including the so-called "Numidian Formation", often detached from its substratum and dated as Late Oligocene to Early Miocene (Guerrera and Martín-Martín, 2014; Thomas et al., 2010). The Massylian unit shows a progressive lateral transition towards the external domains of the South Tethys margin.

Contrary to the older parts of the flyschs, deposited in a passive margin environment, the post-Eocene sedimentation directly recorded the orogenic activity. The basin is fed by immature turbiditic sandstones in the internal parts (Guerrera et al., 2005) and ultramature sandstones from the African craton in its external part (Belayouni et al., 2013; Guerrera et al., 2012; Guerrera and Martín-Martín, 2014; Thomas et al., 2010). The question of whether or not the Maghrebian Tethys was floored by an oceanic substratum is still open. Mafic and mantle rock remnants can be found along with the Jurassic strata of the Mauretanian flyschs (Durand-Delga et al., 2000; Gélard, 1979; Guerrera and Martín-Martín, 2014) but they are very scarce. Durand-Delga et al. (2000) proposed that a probable rifted and hyper-extended continental crust only partially oceanized could have floored the Maghrebian Tethys without having given rise to a true oceanic lithosphere. More data about the mafic and mantle rock remnants in the Kabylies is still required to bring crucial arguments about the nature of the Maghrebian Tethys.

In map view, the Flyschs and $\mathrm{AlKaPeCa}$ domains are discontinuous. To the west, they disappear onshore between $\mathrm{Al}$ Hoceima (Central Rif) and Mostaganem (western Tell) (Figs. 2 and 3). In this area, a problem arises due to the apparent disruption of these domains corresponding to the offshoreonshore limit (Fig. 3). Offshore studies by Domzig et al. (2006) show that the internal zones and the flyschs extend up to some distance offshore (Fig. 2) but the major part of this disruption is of tectonic origin, due to the post-Early Miocene motions of the westernmost part of the AlKaPeCa domain (mostly the Alboran microdomain). Interpretation of this disruption is a major issue. To the east, on the contrary, the
Kabylie-like terranes are continuous from Eastern Tunisia to Sicily and southern Apennines (Auzende et al., 1974; Bouillin, 1986; Bouillin et al., 1999; Catalano, 1987; Catalano et al., 1985; Compagnoni et al., 1989; Mascle et al., 2004; Tricart et al., 1994; Zitellini et al., 1989). Also, the Flyschs domain, notably the so-called Numidian flysch, develops widely in Eastern Algeria and Tunisia.

\subsection{The external domains}

The external domains, representing the former African paleomargin, are described as a pile of thrust-sheets resting on top of a Miocene foredeep in which allochthonous blocks (olistostromes) are included (e.g. Caire, 1957; Vidal, 1971). This foreland basin, well developed at the front of the Rif (Gharb Basin) and in western and central Algeria, becomes narrower in between (in the Gareb-Kebdana promontory [Hervouët and De Luca, 1980]) and even disappears in eastern Algeria and Tunisia, in areas where the foreland itself has been impacted by major inversion tectonics (Fig. 2). The foreland basin, when it exists, rests unconformably on a more or less folded and deeply eroded Mesozoic substratum, namely either the Atlas belt or the "Mesetas" (Fig. 1). It is locally overlain by thin thrust-sheets (few hundred meters to no more than $1.5 \mathrm{~km}$ ), which constitute erosional outliers of the uppermost Tell-Rif units by contrast to lower units interpreted as tectonic windows.

The uppermost units, called here "higher Rif-Tell nappes", are rather homogeneous all along the Tell-Rif. In general, they are detached along an Upper Cretaceous décollement and comprise a typical lithostratigraphic column of deep-marine sediments from Upper Cretaceous up to Lower Miocene without significant unconformity. In the Rif, they comprise the Aknoul, Tsoul, Ouezzane and Prerif nappes or units and correspond to the former cover of the KetamaTanger unit belonging to the Intrarif zone (Suter, 1980a, 1980b). The Aknoul nappe crops out in the eastern Rif and presents the most complete sedimentary pile from Lower Cretaceous to Miocene. The Tsoul nappe (Leblanc, 1979) and Ouezzane nappes (Durand Delga et al., 1962; Hottinger and Suter, 1962) are twin-units detached along a décollement in the uppermost Cretaceous. In western Algeria, they find an equivalent in the so-called "Senonian", "Albo-cenomanian", "Chouala" and "Oligo-Miocene" nappes of the Oran area (Delteil, 1974; Fenet, 1975; Guardia, 1975; Polvêche, 1960). In central Algeria, these units correspond to the complexes "B" and "C" (Caire, 1957; Mattauer, 1958), complex "B" being more or less equivalent to the Aknoul nappe and complex "C" of Ouezzane-Tsoul nappe. In Eastern Algeria and Tunisia, a Miocene frontal basin only scarcely underlines the limit between the Tell and the Atlas. The higher nappes (Kasseb units in Tunisia, Rouvier, [1977]) correspond mostly to tectonic imbrications resting directly over the Lower Cretaceous rocks of the foreland (Vila, 1980). In this case, the sole-thrust of the nappes is a major Upper Cretaceous décollement level allowing the complete decoupling of the upper part of the sedimentary pile.

Below and/or laterally, the lower Tell-Rif units are exposed. They occur in three different structural settings, $i$. e., from outer to inner zones: 


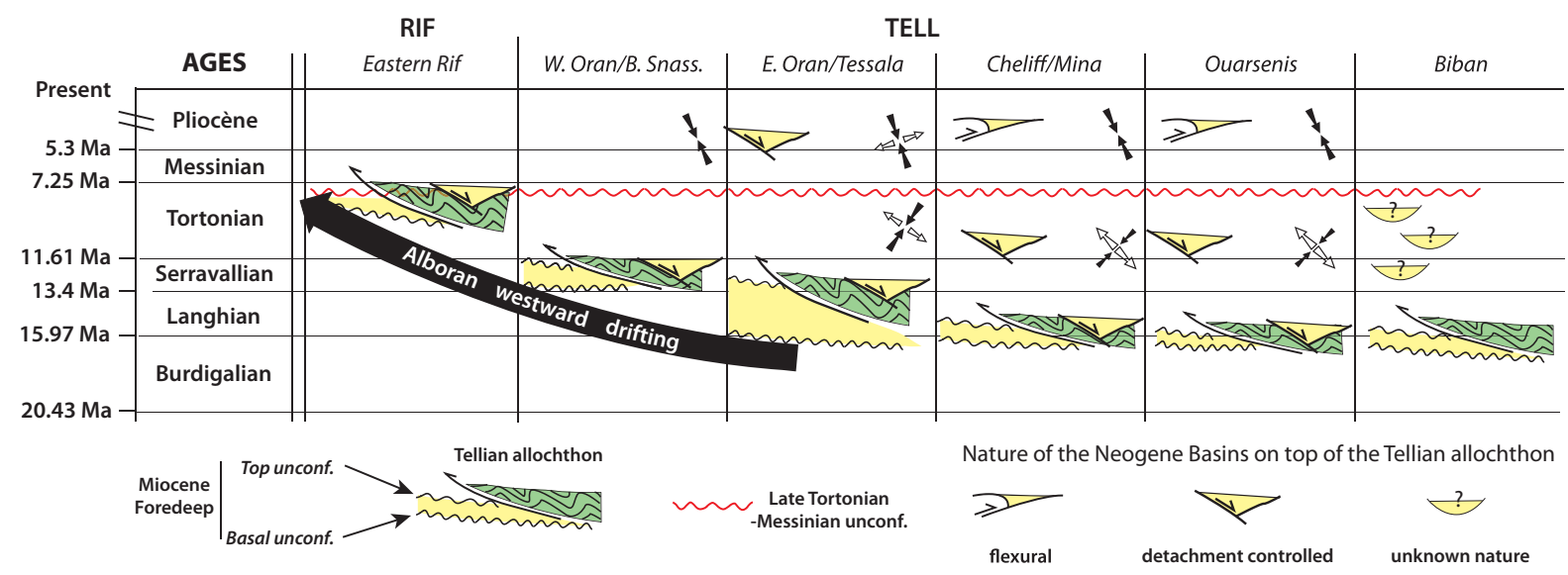

Fig. 4. Time table for the Neogene progression of deformation along Northwest Algeria and North Morocco. When known, the tectonic regime during the basin emplacement is specified. The references for the foredeep age are: (1) Caire (1957), Kieken (1975), Vila (1980) and CourmeRault (1984) for the Biban; (2) Mattauer (1958), Polvêche (1960), Lepvrier (1970) and Roure et al. (2006) for the Ouarsenis; (3) Delteil (1974) and Roure et al. (2006) for the Chelif/Mina Mts; (4) Fenet (1975), Thomas (1985) and Hassani (1987) for the Tessala/East Oran; (5) Guardia (1975), Guardia and Fenet (1987), and Guardia (1990) for the Beni Snassen/West Oran; (6) Septfontaine (1983) for the eastern Rif.

- in the most external zones, they constitute tectonic windows corresponding to late culminations of the African foreland piercing the core of late anticlines refolding the over-lying nappes. This is typically the case from west to east for the "internal Prerif", the "external Mesorif" (Suter, $1980 \mathrm{a}, 1980 \mathrm{~b}$ ) and for the tectonic windows of the Ouarsenis (Mattauer, 1958) and Biban (Caire, 1957) Massifs. A similar configuration is observed more to the east in the Constantinois (Vila, 1980), in Tunisia (Rouvier, 1977), as well as in productive structures for oil and gas in Sicily and Southern Apennines (Casero, 2004 and references therein), with the following particularities: in the Constantinois, there are no Miocene deposits between the autochthonous and allochthonous domains; by contrast, in Italy Pliocene deposits have been preserved attached to the lower plate (Casero et al., 1991). These differences are due to the diachronism of the main overthrusting episode across the Maghrebian-Apenninic orogen. As indicated above, the sole-thrust of the "higher Rif-Tell nappes" remains a décollement (and not strictly speaking a thrustfault) in this case, with only a lateral displacement of younger units over older ones, without any real tectonic duplication (older over younger rocks), except near the tectonic fronts where the nappes can thrust over or be intermingled within young Miocene sediments;

- more to the north, units with significantly stronger deformation than the "higher Rif-Tell nappes" and the above-mentioned tectonic windows are exposed in the eastern Rif and western Tell (Figs. 2 and 3). These so-called External Metamorphic Massifs (EMM) comprise the Temsamane Massif (Andrieux, 1971; Frizon de Lamotte and Leikine, 1985, 1987) in the Eastern Rif and the Oran (Ciszak, 1993; Fenet, 1975; Guardia, 1975), Chelif (Lepvrier, 1978) and Blida (Bles, 1971) massifs in the Western and Central Tell. The best exposures of the EMM are located in the Temsamane Massif (Booth-Rea et al., 2012; Frizon de Lamotte and Leikine, 1985, 1987; Frizon de Lamotte et al., 1991; Jabaloy-Sánchez et al., 2015;
Negro et al., 2007, 2008). They are made up of a stack of tectonic slices with Paleozoic rocks exhibiting HP-LT metamorphic type (7-9 kbar and $330-430{ }^{\circ} \mathrm{C}$; Negro et al., 2007) at the top of the system. The organization of the Oran Massif roughly mimics the Temsamane Massif with increasing metamorphic conditions toward the NW showing the highest grade in the highest Paleozoic slices (Fenet, 1975; Guardia, 1975). In the Temsamane Massif, the HP-LT metamorphism is older than $23 \mathrm{Ma}\left({ }^{40} \mathrm{Ar} /{ }^{39} \mathrm{Ar}\right.$ on white micas: Negro et al., 2008) in agreement with previous ages published by Monié et al. (1984) $\left({ }^{40} \mathrm{Ar} /{ }^{39} \mathrm{Ar}\right.$ on white micas). Jabaloy-Sánchez et al. (2015) $\left({ }^{40} \mathrm{Ar} /{ }^{39} \mathrm{Ar}\right.$ on white micas and amphiboles) retain a Late OligoceneEarly Miocene age for the peak metamorphic event, but an older age (Late Eocene) remains possible. The EMM disappear west of the Nekor fault in the Rif and east of the Greater Kabylie in the Tell (Fig. 2). It is not yet established whether these units are buried at depth below more internal units or if this absence is due to major transition zones that would separate significantly different tectonic domains; north of the EMM, the "northernmost Rif-Tell units" are cropping out. They correspond roughly to the mid-Tellian and partly the high-Tellian units of Wildi (1983). From west to east, they comprise: the Ketama-Tanger unit, the Dahra unit between Oran and Alger and, finally, the Babor unit between the Greater and Lesser Kabylie (Leikine, 1971; Obert, 1981). In general, these units comprise Triassic to Lower Cretaceous sedimentary rocks involved in large recumbent folds and separated into sub-units by important thrust-faults. Importantly, these massifs are tectonically unroofed and their former Upper Cretaceous to Cenozoic cover makes up the current "higher Rif-Tell nappes".

\section{Inputs for a revised Mesozoic-Cenozoic scenario}

All the features presented above must be explained either by the structural inheritance, i.e. the initial configuration of the 
margin, or by the processes active during the inversion of the margin. Lateral displacements, i.e. parallel to the margin, are very important during the two main stages of the geodynamic evolution. We will examine them successively.

\subsection{Oceanization steps in the Tethys realm}

In all the recent kinematic and palaeogeographic restorations (Dercourt et al., 2000; Handy et al., 2010; Schettino and Turco, 2009; Sibuet et al., 2012, Nirrengarten et al., 2018; Biari et al., 2017), Iberia was located far east of its present position relatively to Africa at the beginning of the Jurassic (Fig. 5A). So, at first order, the Maghrebian Tethys is interpreted by the authors as a transform oceanic sea way connecting the Central Atlantic and the Ligurian (Alpine) Tethys. This corridor allowed the left lateral movement of Africa relatively to Iberia during the Jurassic and Lower Cretaceous (Fig. 5).

In detail, the evolution is more complex. Geological data from Iberia and Africa show a set of NE to ENE trending "en echelon" Mesozoic basins, which were more or less subject to tectonic inversion during the Cenozoic. These basins are: the Algarve (Ramos et al., 2016; 2017a, 2017b) and Subbetic (García-Hernández et al., 1989; Vera, 2001) basins on the Iberian side and the Khemisset-Rif (Favre, 1995; Favre et al., 1991), Middle-Atlas, High-Atlas, Sahara-Atlas and TunisiaAtlas basins on the African side (Frizon de Lamotte et al., 2000, 2009 and references therein; Fig. 5A). All of them are slightly oblique to the Atlantic and Alpine Tethys ENE trend but also to the E-W connection (i.e. the so-called Maghrebian Tethys) between these two oceanic domains. It is interesting to try to understand the geometrical and chronological relationships between the intracontinental rift basins and the oceanic domains. An interesting comparison comes to mind with the Aden Gulf opening reworking obliquely former JurassicCretaceous basins (d'Acremont et al., 2005). Another likely similar geological setting might be found in the Gulf of California where the ongoing right-lateral displacement between the Pacific and the North America plates gave birth to pull-apart basins. There, the crust was stretched to various extents. The Salton Sea Basin, located on continental crust, is located along the San Adreas fault and is showing extreme thinning, though being bound by continental crust of normal thicknesses (Han et al., 2016 and references therein). This setting where only portions of the transform zone shows extreme crustal thinning might prefigure the Maghrebian Tethys before the left-lateral motion of Africa after the Bajocian (van Wijk et al., 2017).

For the timing of the Central Atlantic opening, we keep the scenario proposed by Labails et al. (2010) and subsequently modified by Sibuet et al. (2012), Klingelhoefer et al. (2016) and Biari et al. (2017). For Labails et al. (2010), the first oceanic crust appears at $195 \mathrm{Ma}$ (Sinemurian). However, during c.a. $30 \mathrm{Ma}$, the sea floor spreading was very slow $(0.8 \mathrm{~cm} / \mathrm{yr})$. By $165 \mathrm{Ma}$ (base Callovian), an acceleration is recorded up to spreading rates as high as c.a. $5 \mathrm{~cm} / \mathrm{yr}$. For Sibuet et al. (2012), mantle exhumation occurred between 190 and $177 \mathrm{Ma}$ followed by a ridge jump and a new oceanic accretion since $177 \mathrm{Ma}$ (top Toarcian). In the Alpine Tethys, Manatschal and Müntener (2009) propose $166 \mathrm{Ma}$ for the onset of accretion and separation between Europe and Apulia. Equivalent ages for oceanic accretion characterize the Ligurian Tethys (Puga et al., 2011; Tortorici et al., 2009). Following different authors (Andrieux, 1971; Carminati et al., 2012; Doglioni et al., 1997; Guerrera et al., 1993; Handy et al., 2010; Puga et al., 2011; Vitale-Brovarone et al., 2013), it is pertinent to distinguish two branches in the Ligurian oceanic realm with the intervening AlKaPeCa continental domain (Fig. 5A). The western branch has received different names in the literature: West Ligurian ocean (Handy et al., 2010), Penninic ocean (Vitale-Brovarone et al., 2013) and Betic ocean (Puga et al., 2011). We will keep the term West Ligurian Tethys (WLT) to denominate this oceanic domain.

In between the Central Atlantic and the Ligurian Tethys, the Iberian and North-African basins present a similar Triassic to Middle Jurassic evolution. They developed firstly during the Upper Triassic at the same time as the rifting in Central Atlantic (Leleu et al., 2016; Olsen, 1997; Withjack et al., 1998 and references therein) and in the Alpine domain (Bertotti et al., 1993). Then, whereas slow oceanic accretion or mantle exhumation began in the Central Atlantic (Labails, 2007; Sibuet et al., 2012), they recorded a new rifting phase in the Lower Jurassic. This second rifting event lasted until the late Bajocian in the Rif (Favre et al., 1991) and in the Middle Atlas (Sani et al., 2000; Zizi, 1996a, 1996b). In the Tell, seismic lines published by Bracène and Frizon de Lamotte (2002) suggest that the rifting was still active during the lower part of the Dogger. In southern Iberia, the timing is less clear due to a rifting revival characterizing the Iberian Plate during the Late Jurassic-Lower Cretaceous (e.g. in the Algarve Basin: Rey, 2009 and references therein; in the Betics: [Vera, 1988, 2001]). Anyhow, we can postulate that at the end of the Jurassic rifting the North African basins (Rif, Middle Atlas, Sahara Atlas) and their Iberian counterparts (Algarve, Cadix, Subbetic) were already face-to-face (e.g. for a recent reference, Nirrengarten et al., 2018). The development of an E-W transform zone connecting the Alpine Tethys to the Central Atlantic occurred just after.

Given the kinematics of the Central Atlantic (Labails, 2007; Sibuet et al., 2012), it is likely that a "pure" transform movement lasted until $155 \mathrm{Ma}$ (Tithonian). Then, a net decrease of the spreading rates (down to $2.6 \mathrm{~cm} . \mathrm{yr}^{-1}$ ) occurred, coeval to a change in the plate kinematics. The net result was an increase of the distance between Iberia and Africa. From a chronological point of view, this scenario is consistent with the formation of the Ketama-Tanger oceanic domain at the end of Jurassic times. Thus, this basin filled with flyschs outcropping in the Ketama unit simply appears as an appendix belonging to the Flyschs Basin itself. It is worth noting that a similar timing is also recognized for mantle exhumation along the south Iberian margin in the Gorringe Bank area (Girardeau et al., 1998; Jiménez-Munt et al., 2010).

Such a kinematic scenario could explain why mantle exhumation and onset of oceanic crust accretion occurred later in the Maghrebian Tethys than in the main Atlantic domain and possibly later than in the Ligurian domain. The left-lateral movement of Africa associated with little divergence lasted during the whole Early Cretaceous and the beginning of the Upper Cretaceous, until the onset of the Africa-Eurasia convergence at $84 \mathrm{Ma}$ (Santonian). 

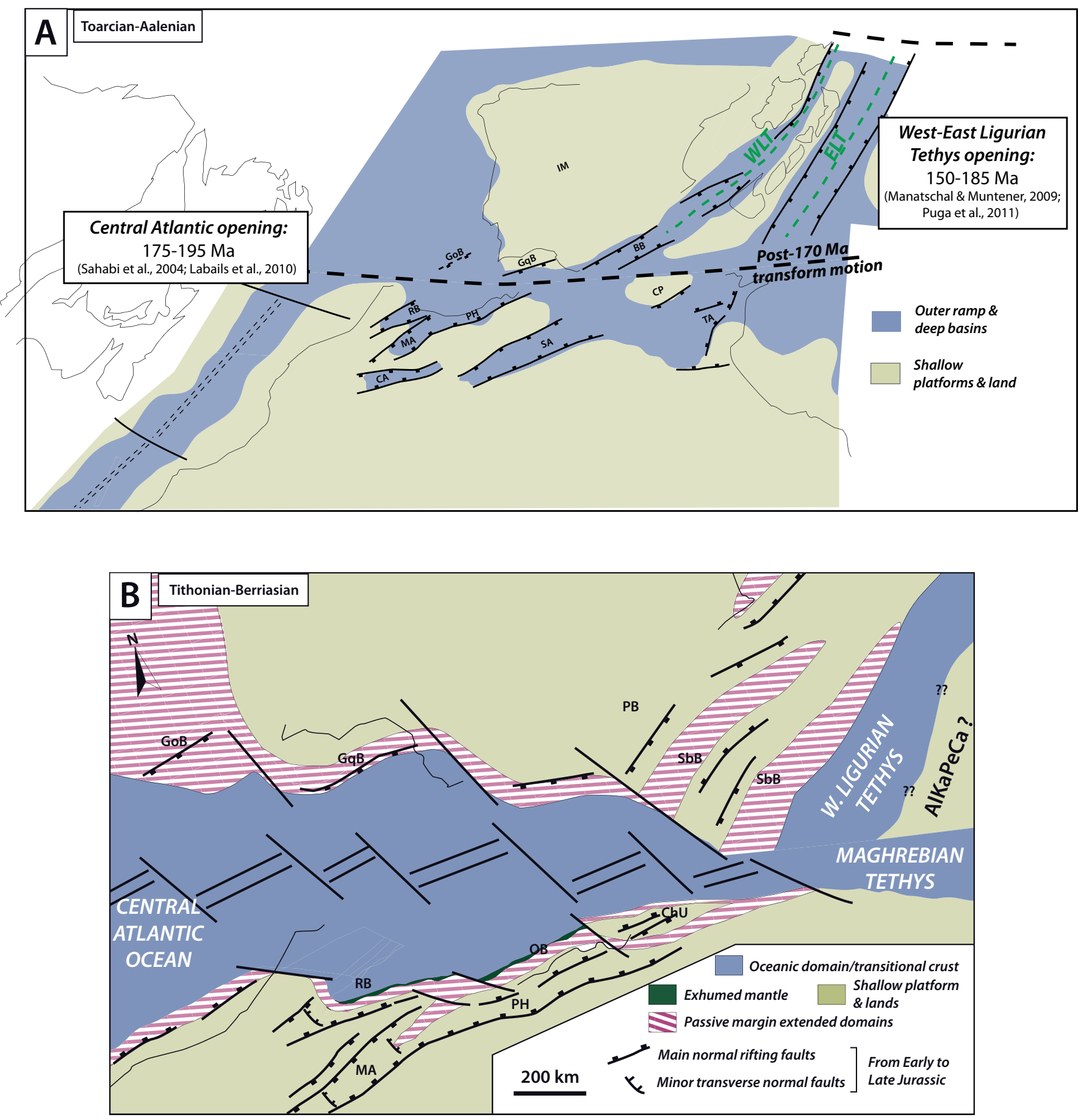

Fig. 5. Paleogeographical reconstructions for the Early-Middle Jurassic and the end of the Late Jurassic. (a) Early-Middle Jurassic (ToarcianAalenian) wide-scale paleogeographical reconstruction. The well-established rifted domains are the Central Atlantic Ocean and the East Ligurian Tethys. In between, generally NE-SW oblique basins are more or less opened, from intraplate rift basins like the Atlas basins to embryonic oceanic domains like the Rif Basin, or the Betic Basin where an oceanic domain was likely preserved. The map and ages of break-up are mostly based on Aït Ouali (1991), Dercourt et al. (2000), Favre (1992), Fedan (1988), Handy et al. (2010), Labails et al. (2010), Lombardo et al. (2002), Manatschal and Müntener (2009), Puga et al. (2011), Ramos et al. (2017b), Sahabi et al. (2004), Sallarès et al. (2013), Schaltegger et al. (2002), Soussi (2000) and the references. (b) Focus on the western tip of the Maghrebian Tethys by the end of the Late Jurassic, after the east-southeastward drift of Africa since the Bajocian. This sketch illustrates the transition from extended and hyper-extended domains to exhumed mantle and/or oceanic crust (maybe transitional crust for the whole Maghrebian Tethys). The reconstruction is based on Dercourt et al. (2000), Favre et al. (1991), Ramos et al. (2017b), and Vera (2001). The Rifian Basin, "Pays des Horsts" of the French authors (Northeast Morocco) and Chouala unit is our re-interpretation in terms of paleogeography of the field data presented in Ciszak (1993), Fenet (1975), Guardia (1975), and Michard et al. (1992, 2007). AB: Algarve Basin; BB: Betics Basin; CA: Central High Atlas; ChU: Chouala Unit; CP: Csontantine Platform; ELT: East Ligurian Basin; GB: Gorringe Bank; IM: Iberian Massif; MA: Middle Atlas; OB: Oran Basin; PB: Prebetics; PH: "Pays des Horsts"; RB: Rifian Basin; SA: Sahara Atlas; SbB: SubBetics; TA: Tunisian Atlas; WLT: West Ligurian Basin. 


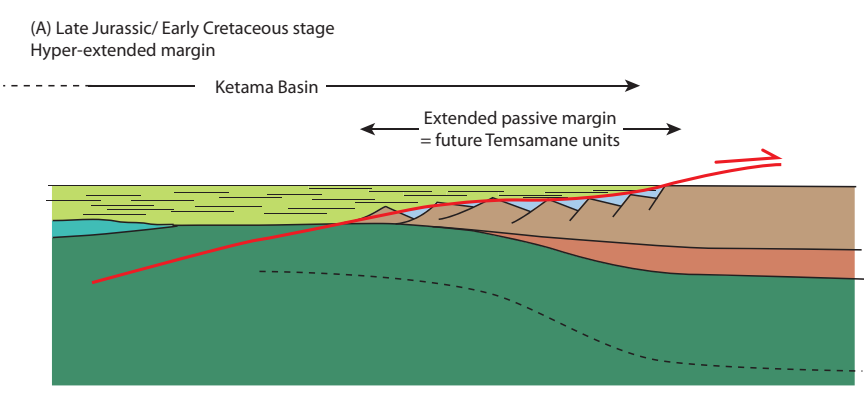

(C) Early/Middle Miocene transpressional exhumation

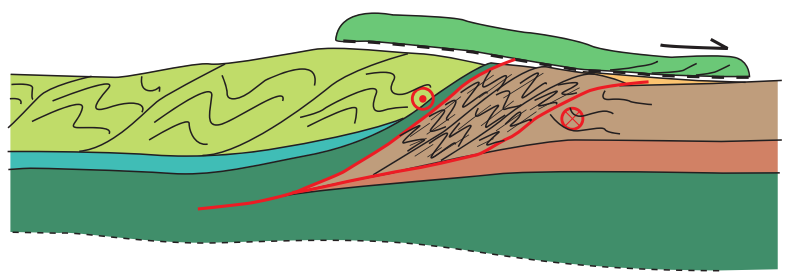

(B) Late Cretaceous(?)-Eocene Subduction stage
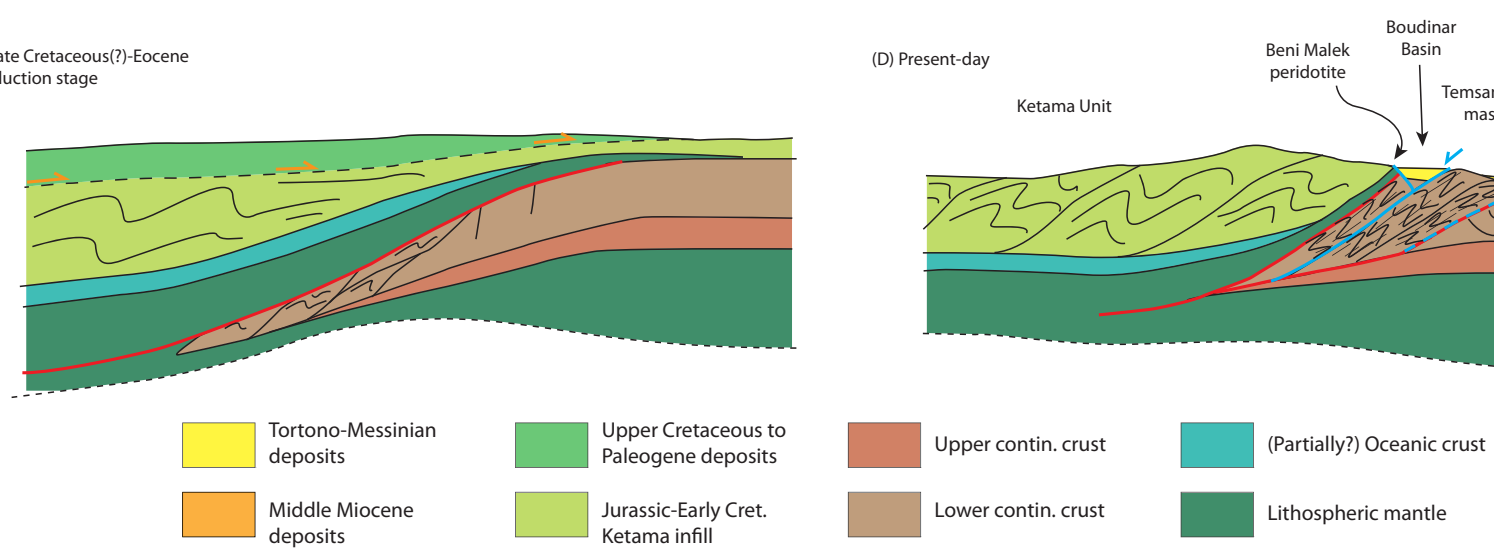

Fig. 6. Schematic cross-sections illustrating the evolution from oceanization to closure of the Rifian Basin.

\subsection{Spatial distribution and meaning of the External Metamorphic Massifs (EMM)}

From the general configuration described above (Sect. 2.2), we think that the existence of the EMM cannot be understood without underlining their link with the "northernmost Rif-Tell" units on the one hand and with their wedge-top Miocene basins on the other hand. The relationships between the KetamaTanger unit and Temsamane massif, in the eastern Rif, well depict the first point.

The Ketama-Tanger unit (Rif, Morocco) is particularly interesting because it shows serpentinite bodies along its eastern border (the Beni Malek massif), interpreted as exhumed subcontinental mantle (El Azzab et al., 1997; Michard et al., 1992, 2007). Therefore, it is likely that the northeastern part of the Ketama-Tanger unit might be floored by an oceanic basement. In contrast, its southernmost part exhibits Upper Triassic salt and Jurassic breccias consistent with a deep margin setting (Favre, 1992). The precise nature of the basement is out of scope of our study but might be heterogenous, which could be important in terms of mechanical behavior during the Cenozoic inversion (e.g. salt $v s$. no salt). In any case, the whole Ketama-Tanger unit represents a former deep basin (Andrieux, 1971; Favre, 1995; Frizon de Lamotte and Leikine, 1985), rather than a continental block (micro-continent) as it has been recently proposed (Michard et al., 2007, 2014) in their palaeogeographic proposals to account for the existence of the peridotites

Although slightly metamorphic in its eastern part (no more than early greenschist facies, see Andrieux, 1971; Frizon de Lamotte and Leikine, 1985), the Ketama-Tanger unit does not exhibit HP metamorphism. Therefore, we must consider that the adjacent Temsamane units were buried and then exhumed, still maintaining the Ketama-Tanger unit as a roof structure. This means that the subduction explaining the HP-LT metamorphism of the Temsamane units was an intra-oceanic NW-dipping subduction allowing the burial of the thinned African margin (Temsamane) at intermediate pressures but keeping close to the surface the "oceanic" Ketama-Tanger basin (Fig. 6). Such a configuration is unusual because, in general, the subducted domain is the oceanic one. However, a comparison comes to mind with the Oman belt where tectonic windows exhibiting HP-LT metamorphism affecting continental crust support the non-metamorphic Semail ophiolite (see Duretz et al., 2016; Goffé et al., 1988; Rioux et al., 2016).

The "oceanic" nature of the northeastern part of the Ketama-Tanger Basin raises two questions: (1) how this NEtrending basin was ending to the SW, toward the African Plate, and (2) how this deep basin was connected to the "Flyschs Basin", interpreted as the main boundary between Africa and Iberia?

Regarding the first question, a " $\mathrm{V}$ " shape is well identified for the Ketama-Tanger Basin (Favre, 1992; Favre et al., 1991). The tip of the "V" is located south of the Prerif Ridges (formerly, "Rides Prérifaines" of the French authors) in the Khemisset Basin (Faugères, 1978; Favre, 1995). Between the Prerif Ridges and Ketama, evidences of units with "oceanic affinities" have been described in the Sofs (Benzaggagh, 2011; Bulundwe Kitongo et al., 1987) and Senhadja units (Favre, 1992; Papillon, 1989), belonging to the internal Prerif and external Mesorif (Benzaggagh et al., 2014). These units, possibly showing remnants of the SW extension of the former Ketama Basin (the Mesorif Suture Zone of Michard et al., 2014), present a chaotic aspect with a complex association of magmatic rocks (gabbro, basalt), Lower-Middle Jurassic carbonates (more or less metamorphosed; from our own 

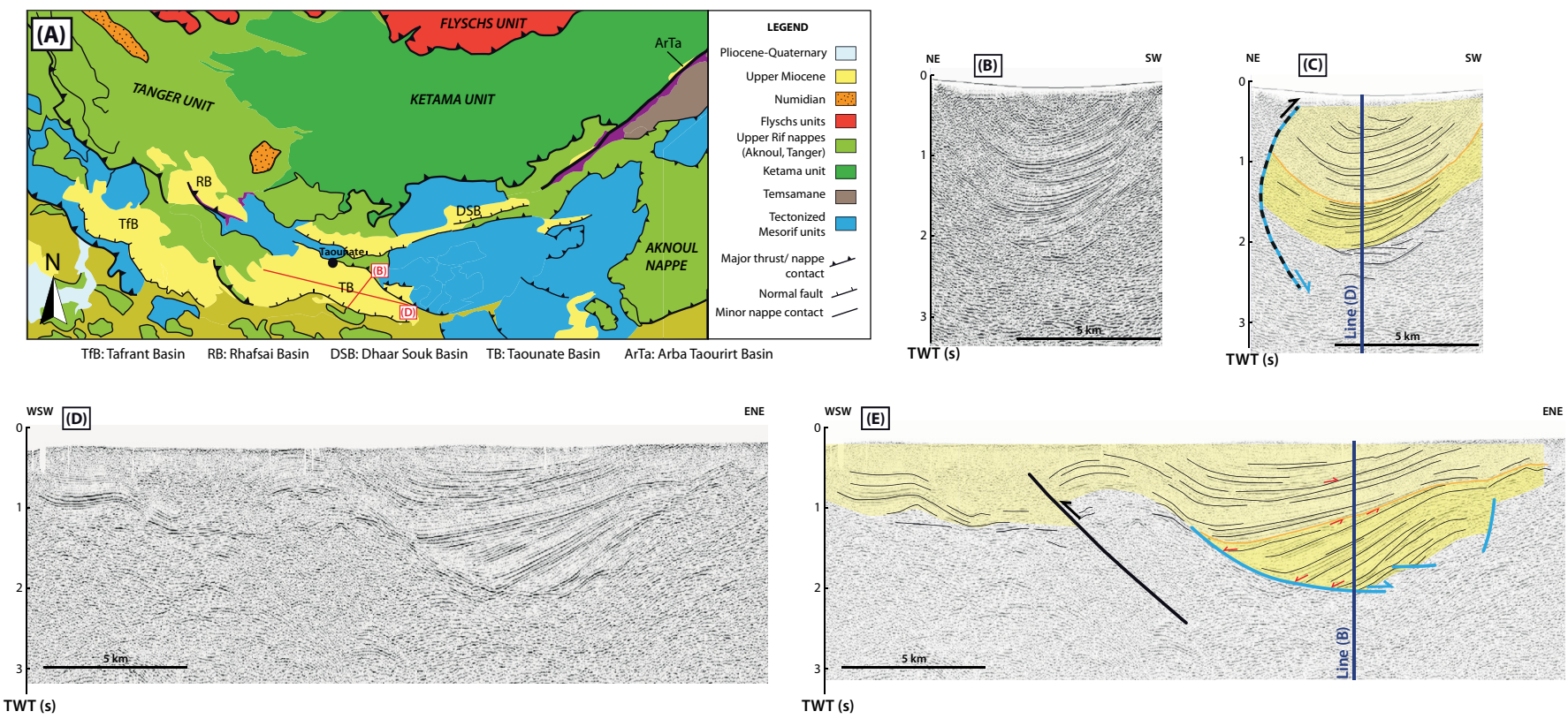

Fig. 7. Wedge-top Neogene basins of the Mesorif. (A) Geological map of the Abra Taourirt-Taounate basins area. Location of the seismic crosssections (B) and (D) is given on (A). (B, D) Two seismic cross-sections from the Taounate Basin, from Samaka (1999). The sections are roughly perpendicular to illustrate the bias that can exist if one only looks at the NNE-SSW to NE-SW sections. (C, E) Neogene interpretation of the two seismic cross-sections (B) and (D), respectively. This is mostly based on the interpretations by Samaka et al. (1997) and Capella et al. (2017) given they propose a similar subdivision for the Neogene infill, divided into two main sequences. Blue faults show the first normal motion along the faults, whereas black lines show the inverse posterior motion.

observations they can locally be marbles, but are still poorly described in the literature [Benzaggagh et al., 2014; Michard et al., 2014]) and Upper Jurassic turbidites. They have no equivalent in the Tell, except possibly in the Chouala Nappe (western Tell; Delteil, 1974; Fenet, 1975; Guardia, 1975; Polvêche, 1960) in which "blocks" of Jurassic carbonate are described.

Considering the second question, elements that may correspond to the Beni Malek serpentinites and the Temsamane units, but more scattered, are known in the western Tell (Oran region) (Ciszak, 1993; Fenet, 1975; Guardia, 1975; Fig. 2). They may also extend up to the westernmost boundary of the Greater Kabylie in the Blida Massif, across the Chelif Basin (Bles, 1971; Lepvrier, 1971; Lepvrier, 1978). These structural units display more intense deformation than the upper Tell units and the external tectonic windows, but still less than the Oran and Temsamane EMMs and are not associated to peridotites. Nonetheless, from Oran to the Chelif Basin, numerous Triassic salt plugs are bringing up to the surface xenoliths of deep metamorphic crustal or mafic rocks and peridotites (Kornprobst and Delteil, 1976; Midoun, 1989; Midoun and Seddiki, 2016). Although the salt may have undergone significant horizontal displacements during tectonic transports, it testifies for a former widespread extensional context, likely linked to the Triassic-Jurassic rifting phase.

All these observations suggest that the Ketama-Tanger Basin developed and probably enlarged to the NE. The Ketama-Tanger Basin shares with the Flyschs domain the turbiditic sedimentation that invaded the whole LigurianMaghrebian Tethys during the Early Cretaceous (Bouillin, 1986; Durand-Delga et al., 1999; Guerrera et al., 1993, 2005; Guerrera and Martín-Martín, 2014). In both cases, the
Cenozoic clastics sourced in Africa (Wildi, 1983). So, it appears realistic to consider that the Ketama-Tanger Basin and the Flysch basin were in fact a unique basin connected through a complexly rifted and segmented zone along the southern Tethys (at the present-day location of Morocco and West/ Central Algeria; Fig. 5). Their differences concern mainly the state of deformation, higher in Ketama-Tanger than in the flyschs, and their initial position, Ketama being located more to the west but not their initial sedimentary infill.

\subsection{Relationships between the EMM and wedge-top Neogene basins}

The occurrence of intra-mountain Miocene to Pliocene basins on top of the nappes stack characterizes the central and eastern Rif as well as the western Tell area (Figs. 7 and 8). In the Rif, these basins (namely the Taounate, Rhafsaï, Tafrant, Dahar Souk, Arbaa de Taourirt, Kert and Boudinar basins, see Fig. 7) constitute the north-Rif corridor. During the Upper Miocene but before the Messinian crisis, this corridor was a marine connection between the Mediterranean and the Atlantic (Capella et al., 2017; Wernli, 1988). In the western Tell, the wider Chelif Basin occupies a similar structural position on top of the Tell nappes (Roure et al., 2012; Thomas, 1985; Figs. 2, 3 and 8). The Chelif is older than the Rif basins: below the Late Miocene, the sedimentary pile is known down to the Aquitanian(?)-Burdigalian (Neurdin-Trescartes, 1992).

Classically, the central and estern Rif and Chelif basins were interpreted as "post-nappes basins", that means basins post-dating the main tangential phases and the nappes emplacement, subsequently reworked during a late compres- 

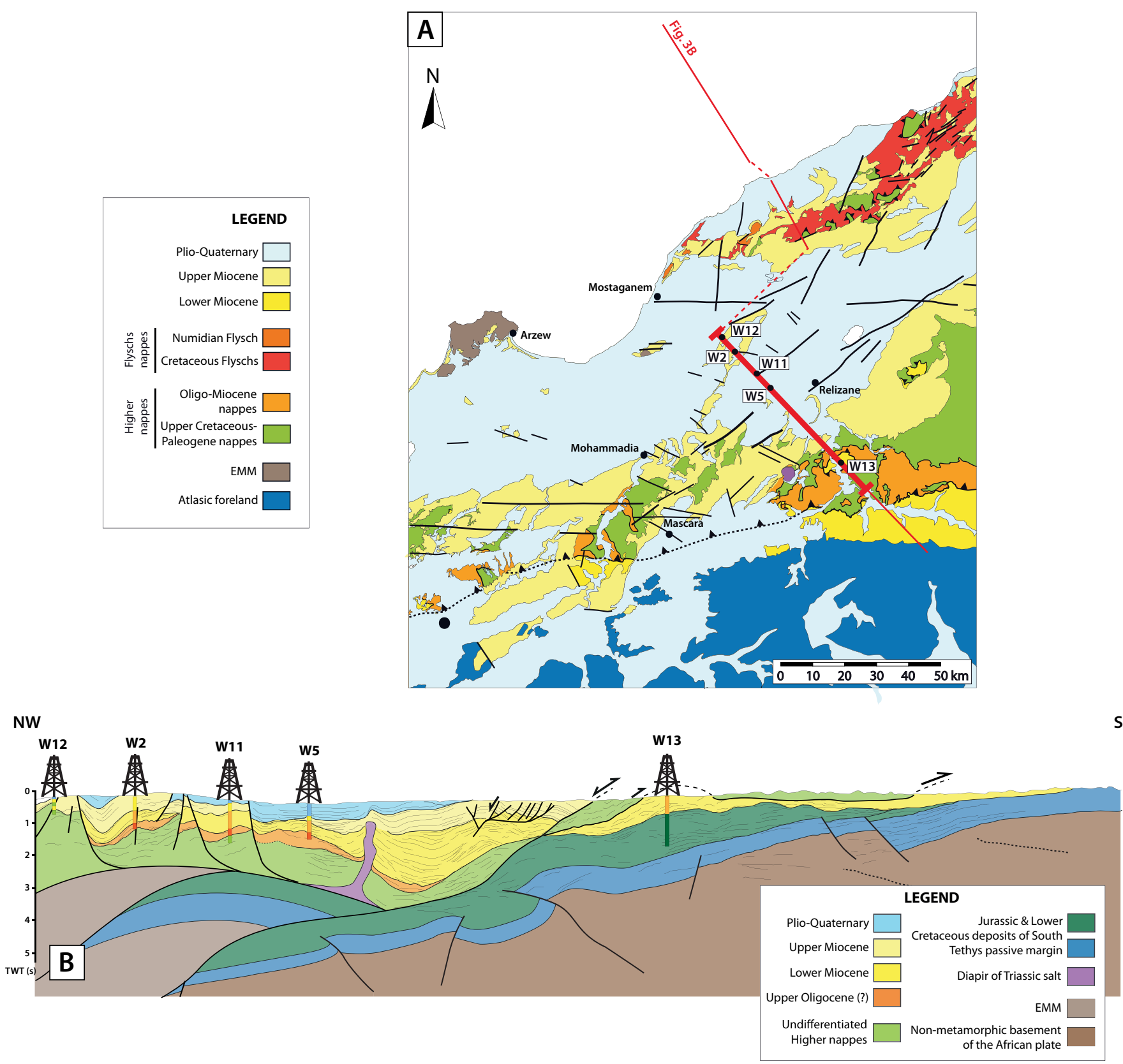

Fig. 8. Post-nappes Chelif Basin in the western Tell. (A) Geological map of the Chelif Basin area. Location of the seismic cross-sections (B) is given on (A). (B) Seismic cross-section with line drawing from the southwestern end of the Chelif Basin (modified after Roure et al., 2012 and the original data).

sional event (Capella et al., 2017; Morel, 1987; Tejera de Leon et al., 1995). However, such a designation is not suitable because these basins have the same age as the respective adjacent flexural basins supporting the nappes. As illustrated by the cross-sections A and B (Fig. 3), they are better described as wedge-top basins developed during the activity of the orogenic prism.

Focusing on the mechanisms of formation of the central Rif wedge-top basins, Samaka et al. (1997) evidenced, using industrial seismic data, early extensional faults delineating sedimentary wedges (Fig. 7D and E). These faults are bounding the southern or southwestern flanks the basins
(Fig. 7A). The basins are consequently not only synclines as promoted by Suter (1980a, 1980b), Tejera de Leon et al. (1995) or Capella et al. (2017) but initially developed as extensional basins (Flinch, 1994; Samaka et al., 1997), subsequently involved in compressional deformation. In the central Rif, the basins rest over the Mesorif tectonic windows. In the eastern Rif, the basins are fringing the Temsamane EMM to the NW following the Nekor Fault. At large scale, the basins consequently underline the "external or Mesorif suture zone" defined by Michard et al. (2014). From a chronological point of view, they developed during the late stages of the Temsamane Massif exhumation, which 


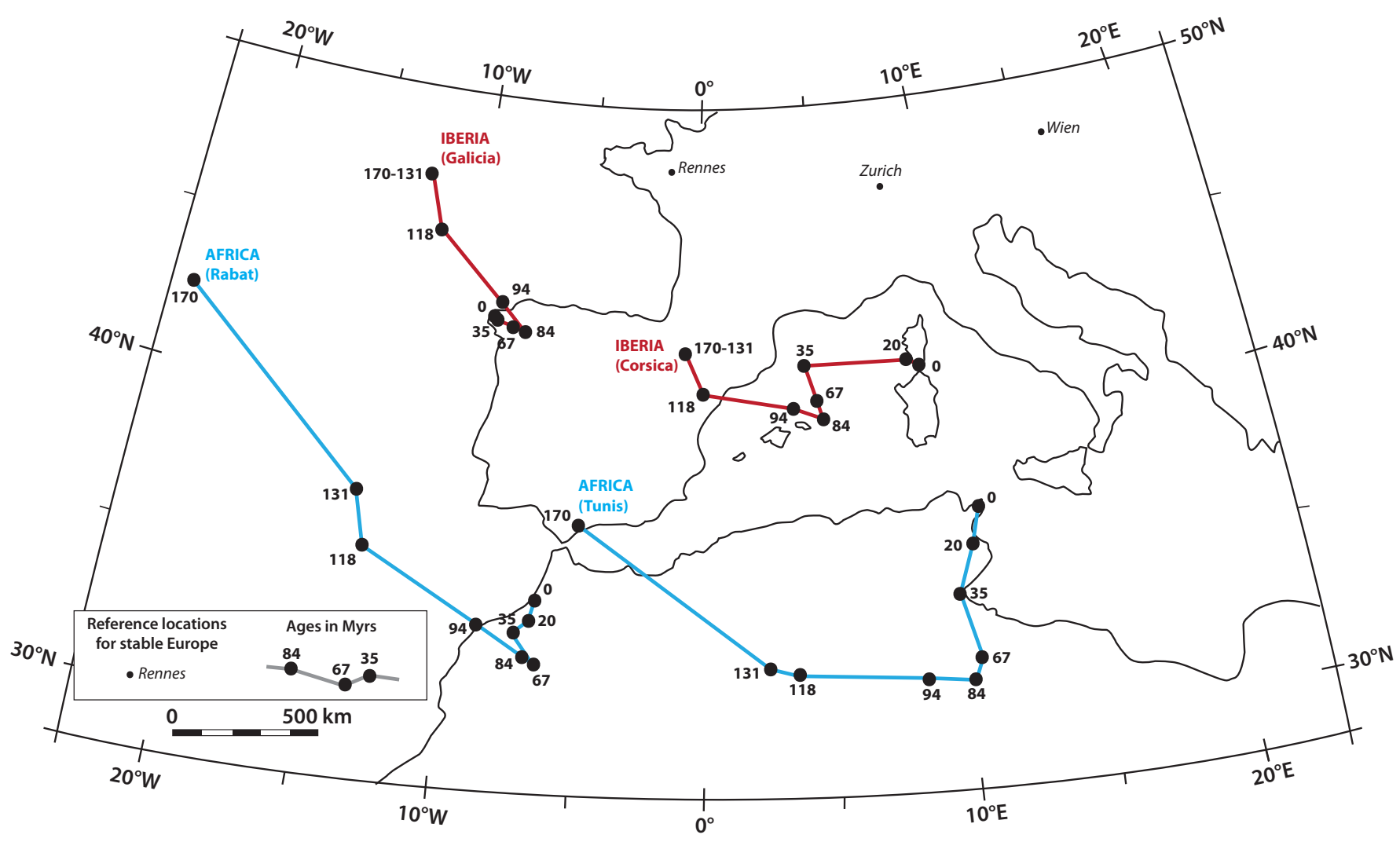

Fig. 9. Motion paths of four points located on the Africa, Iberia and Corsica plates from Middle Jurassic to present (modified from Handy et al., 2010). The reference is stable Europe, using three references locations.

occurred between 15 and $10 \mathrm{Ma}$ (Negro et al., 2008). Given that this exhumation developed in a context characterized by intense ENE stretching and top to the west shearing (Frizon de Lamotte, 1987; Frizon de Lamotte et al., 1991; JabaloySánchez et al., 2015; Negro et al., 2007, 2008), the formation of the Rif wedge-top basins corresponds to the final lateral collapse of this system. By the Late Tortonian, they are involved in a compressional setting explaining their present syncline-like shape.

The tectonic history of the Chelif Basin appears longer and more complicated. A three-step scenario can be proposed. During the first step (Aquitanian(?)-Burdigalian to Langhian), the basin developed as a piggy-back basin over the moving higher Tell nappes, which in turn emplaced southward over a Lower Miocene foredeep. During a second step (Late Langhian-Serravallian up to Tortonian), a set of low-angle normal faults with a possible left-lateral movement developed (Meghraoui et al., 1986; Roure et al., 2012; Thomas, 1985). These faults controlled the Serravalian to Late Miocene filling of the basin. As in the Rif, these two first steps can be related to the progressive exhumation of the EMM (Oran and Chelif massifs) through major north-dipping fault connecting the EMM deformation to the Chelif infill during the whole Miocene (Figs. 3 and 8). Due to the lack of recent structural and petrographic work, the precise kinematics of these tectonic processes is unknown. However, given the ubiquitous existence of an E-W to ENE trending and low dipping lineation in the Algerian EMM (Guardia, 1975; Kireche, 1977), it is likely that, as in the Temsamane, the exhumation occurred in a transcurrent context. Finally, as in the Rif, during a third step, the Chelif region suffered a late contractional event by the Late Tortonian(?)-Pliocene (Meghraoui, 1982; Thomas, 1985). This compressional tectonic activity has remained operating up to now.

The Chelif Basin (Figs. 3B and 8) and the north Rifian corridor basins (Flecker et al., 2015; Wernli, 1988) do share a similar structural position within the belt. They are all localized in the western parts of the belt, the latter being characterized also by the presence of the EMM and frontal flexural basins. From a palaeogeographic point of view, they are superimposed to the hinge region (locus of the former subduction where the African plate was underthrust) between the stable Meseta domain and the Ketama-Oran deep basin. In spite of being shifted in time, the deformations in the Chelif and Rif basins occurred under extensional stresses during the Late Neogene (from Langhian to Late Tortonian and from Late Tortonian to Messinian, respectively), which accompanied the final exhumation of the EMM. This timing suggests that both the exhumation of the EMM and the development of wedge-top basins are related to the westward translation of the Alboran domain. The general compressional N-S stresses resumed in the Late Tortonian-Messinian in Morocco, and Plio-Quaternary times in Algeria (among others: Arab et al., 2016; Déverchère et al., 2005). 

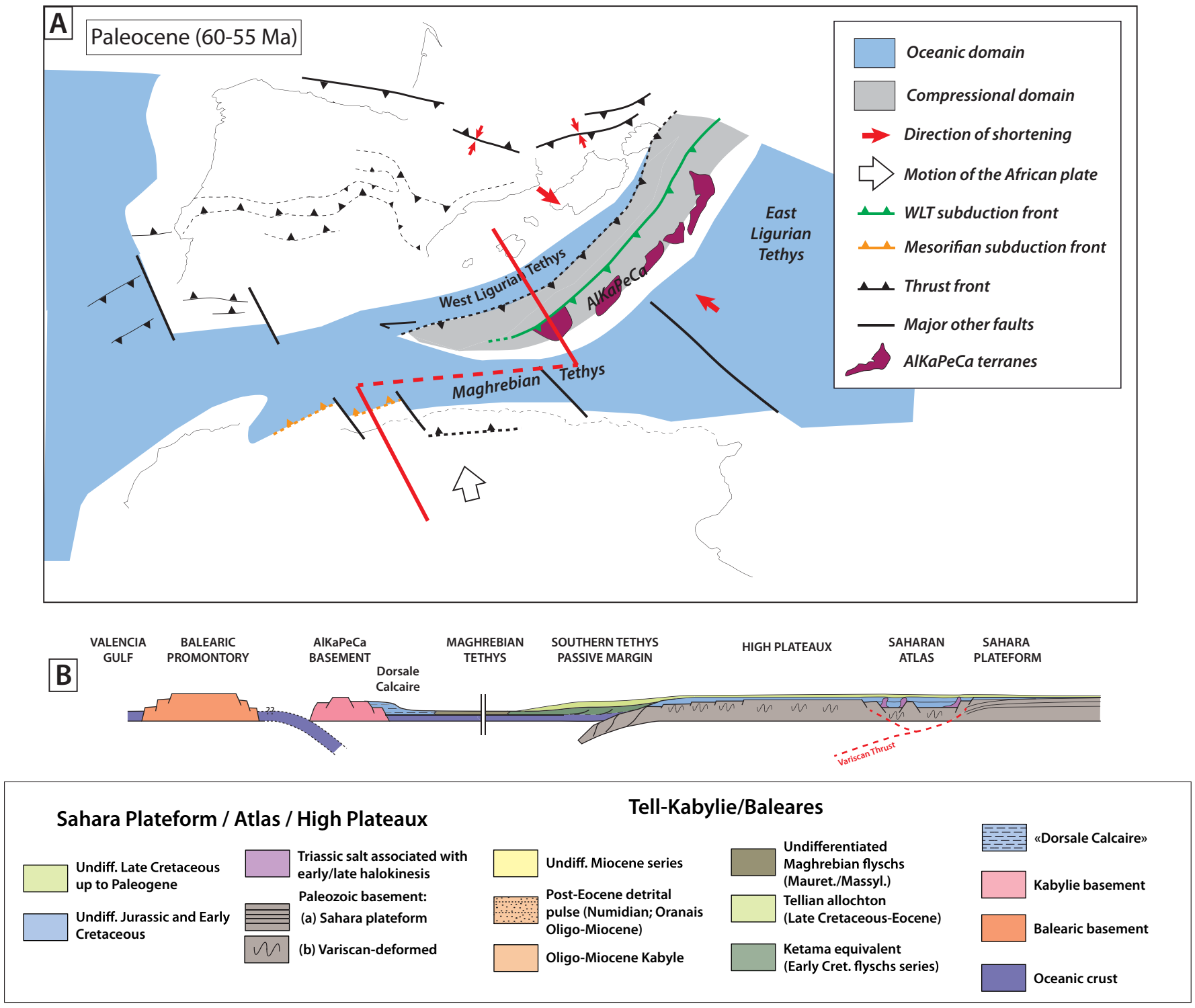

Fig. 10. (a) Paleogeographic reconstruction for the Paleogene (60-55 Ma). The cross-section below (b) is only a simpified one in order to illustrate the depth evolution of the Maghrebian Basin and its boundaries up to the present-day. It shows the evolution of the system on each figure from Figure 10 to 16.

\section{Palaeotectonic Alpine steps: a Late Cretaceous-Cenozoic history}

The Tell-Rif records the Africa-Europe convergence since its onset (i.e. $84 \mathrm{Ma}$ ). We recognize three main periods separated by major geodynamic reorganizations: (1) Late Cretaceous to Late Eocene, (2) Oligo-Miocene and (3) Pliocene-Present.

\subsection{The first tectonic inversions of the Southern Tethys margin, importance of the Middle-Late Eocene event (Figs. 10-11)}

The convergence between Africa and Eurasia follows a counter-clockwise rotation for fixed Eurasia around a pole located in the Central Atlantic, at small distance from the
Moroccan margin (Handy et al., 2010; Rosenbaum et al., 2002; Fig. 9). Consequently, between 67 and $35 \mathrm{Ma}$, the amount of convergence is two times greater in Tunisia than in Morocco. During this period, the trajectory is almost and globally N-S with an inflection toward the NW by $45 \mathrm{Ma}$. The convergence is accommodated by the subduction of the different oceanic domains: the Maghrebian Tethys and the two branches of the Ligurian Tethys (Fig. 10). The subduction process is not continuous but disturbed by compressional adjustments indicative of periods of strong coupling between the two plates and jumps from an oceanic domain to another one with the $\mathrm{AlKaPeCa}$ domain in between.

As everywhere along the South Tethys margin, a first compressional tectonic event is recorded at the onset of AfricaEurasia convergence (84 Ma) (Frizon de Lamotte et al., 2011 and references therein). This event is known everywhere in the northern part of Africa as the "Santonian Event" (Guiraud 


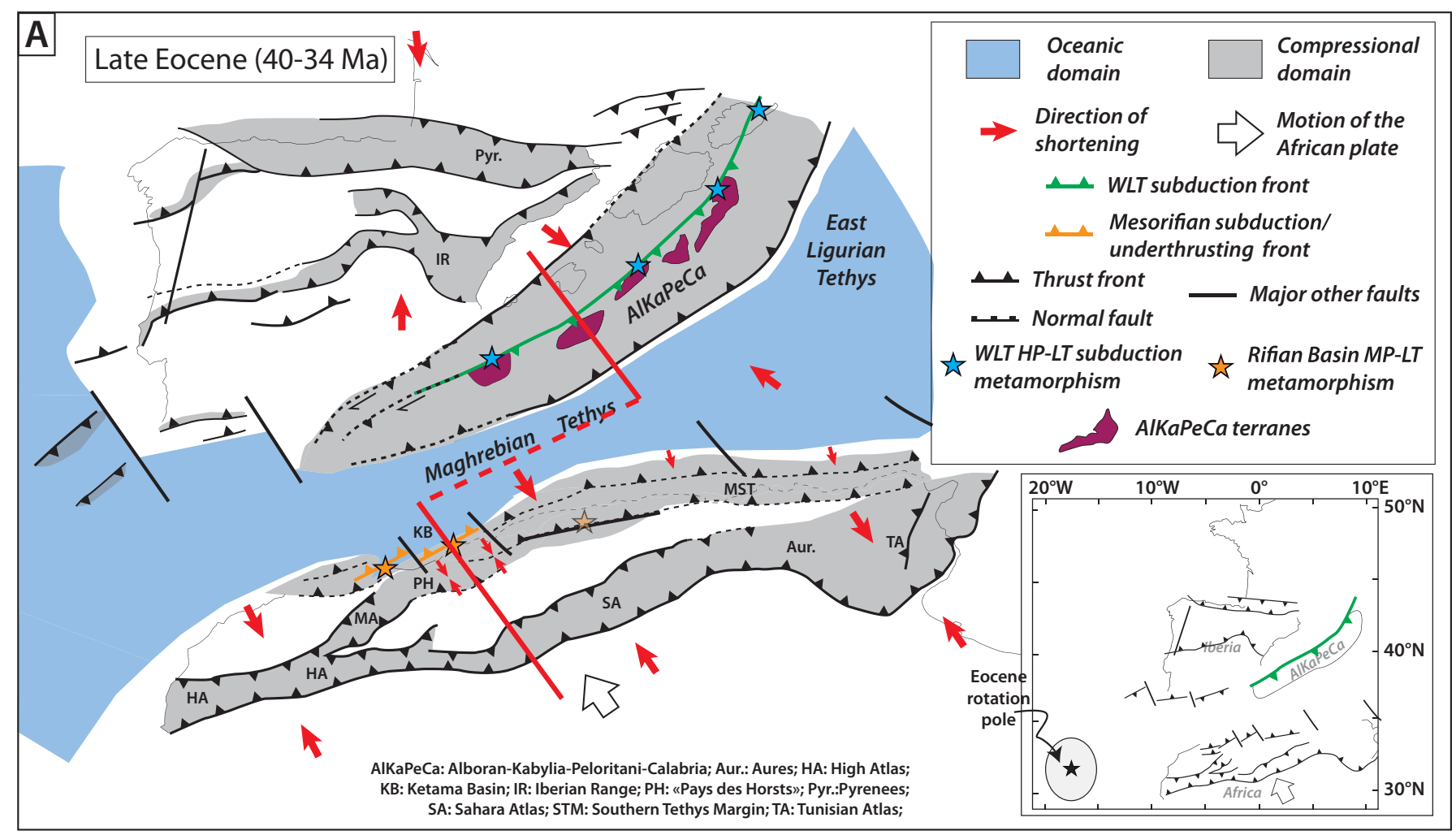

B

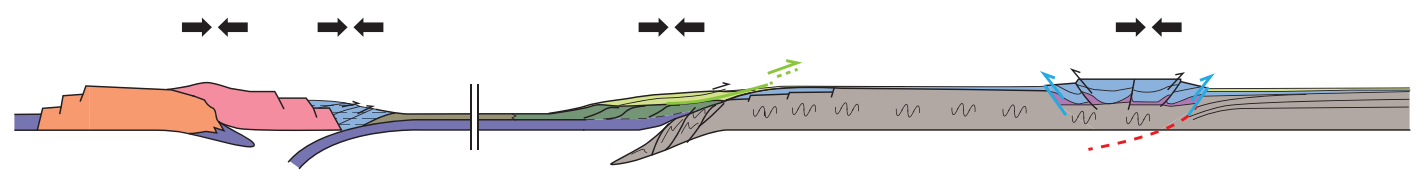

Fig. 11. (a) Paleogeographic reconstruction for the Middle-Late Eocene (40-34 Ma). (b) Simplified cross-section of the Maghrebian Basin. Same legends than in Figure 10b. (c) Structural sketch of the Eocene configuration for the closure of a triangle basin.

et al., 2005). It is also known in Europe (among others, Kley and Voigt, 2008; Jolivet et al., 2016; with references therein). Nonetheless, its effects remain weak or overprinted by subsequent events in the Tell-Rif.

A major compressional tectonic event occurred during the Middle-Late Eocene (45 to $35 \mathrm{Ma}$ ), i.e. at the end of the period of oblique convergence indicated above (Fig. 11). Laffitte (1939), who called it "Atlas Event", firstly identified this event in the Aurès Mountains (Algerian Atlas). Frizon de Lamotte et al. (2000) have shown that it was general at the scale of the whole Atlas from Agadir to Tunis, as subsequently confirmed by Frizon de Lamotte et al. (2009), Khomsi et al. (2004, 2016) and Leprêtre et al. (2018).

In the external Tell-Rif, the unconformity of the Oligocene (?)-Miocene sediments of the foredeep over the Atlas structures is recognized since a long time (Caire, 1957; Mattauer, 1958; Suter, 1980a, 1980b; and references therein). More precisely, Fenet et al. (1969), Delteil (1974), Fenet (1975) and Guardia (1975) defined an "intra-Lutetian" event responsible for tangential movements, strong deformation and development of regional metamorphism in the western Algerian Tell. An analog configuration exists in the eastern Algerian Tell (Vila, 1980), even if the Priabonian age proposed by this author is a little bit younger. In the eastern Rif, in the
Temsamane EMM (Figs. 2 and 6), unambiguous trace of HPLT metamorphic type have been described (Negro et al., 2007, 2008) and is associated with a subduction or deep underthrusting of this continental domain below the Ketama-Tanger oceanic unit (see above). The age of burial or exhumation related to this stage is not very well defined. It should be at least Oligocene and possibly older (Monié et al., 1984; Negro et al., 2007). Laterally, in the Mesorif zone, Oligocene (?) and Lower Miocene conglomerates rest unconformably over the older Mesozoic rocks (Favre, 1995; Favre et al., 1991; Leblanc, 1979; Marçais, 1936; Vidal, 1971). The subsequent exhumation of the Temsamane, occurring in a transcurrent context, is dated as Langhian to Late Serravalian/ Early Tortonian (Frizon de Lamotte, 1987; Negro et al., 2008; Jabaloy-Sánchez et al., 2015). The deformation of the Mesorif is better correlated to a Late Eocene-earliest Oligocene deformation with a stratigraphic gap from the Early to the Late Oligocene. As a consequence of this interpretation, we relate the Oran up to the Chelif EMMs to an eastward prolongation of the area affected by compression during this period. This explains the similar structural setting comprising peridotites and the metamorphic units of the Oran EMM (Michard et al., 2006). Further works of dating for these metamorphic units are required to confirm this hypothesis. Farther east, where 


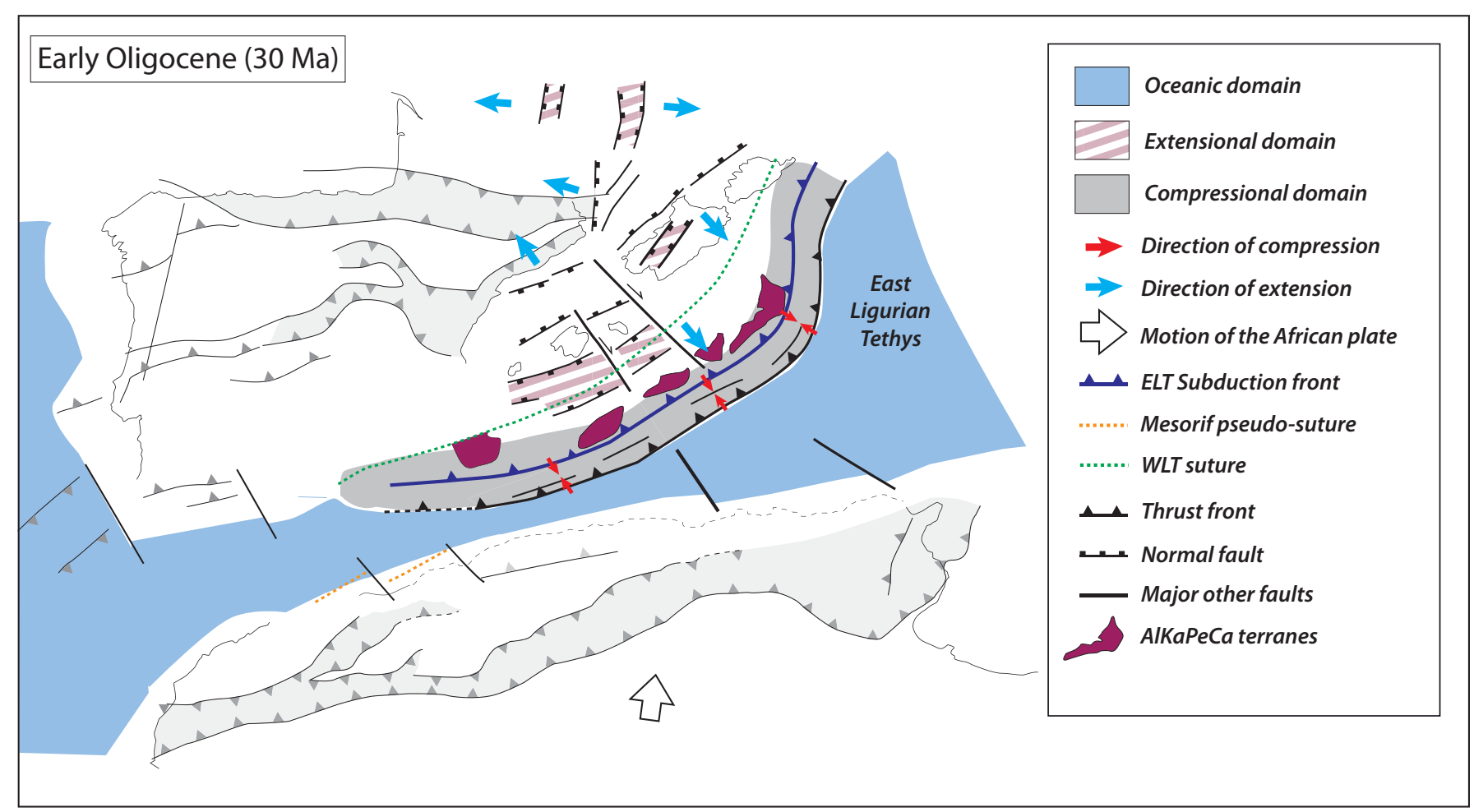

Fig. 12. Paleogeographic reconstruction for the early Oligocene (34-30 Ma).

deformation is less intense, the EMM would result from the northward underthrusting of the African plate, but it may not have reached such HP conditions like in the western parts in spite of experiencing the same type of gradient.

Therefore, during the Middle-Late Eocene, North Africa was affected by more or less intense shortening, not only in the Atlas (the concept of "Atlas" event) but also in the external Tell-Rif where it is locally associated with HP-LT metamorphic type (Fig. 11). This event is coeval with the so-called "Pyrenean" event, evidenced not only in the Pyrenees but also in the whole Iberian Plate and even over the entire Western European domain (Bergerat, 1985; Casas Sainz and Faccenna, 2001). It correlates with the age of the HP-LT metamorphic type in the Alps (Agard et al., 2001; Beltrando et al., 2010; Bousquet et al., 2008), Corsica (Vitale-Brovarone et al., 2013) and Alboran Domain (divided into [1] the Alpujarrides where a Paleogene event can be evidenced: Monié et al., 1994; Platt et al., 2005 and [2] the Nevado-Filabres where an Eocene and a more recent Miocene events are recorded: Augier et al., 2005; $\mathrm{Li}$ and Massone, 2018). Concerning this last domain and according to Vitale-Brovarone et al. (2013), we consider that the collision between $\mathrm{AlKaPeCa}$ and the eastern Iberian margin, that is to say the closure of the West Ligurian Tethys, occurred at the same time (see also Schmid et al., 2017).

However, this major tectonic reorganization did not correspond to a direct collision between Iberia and Africa. At that time, the Maghrebian Tethys was still an oceanic seaway connecting the Atlantic and the East Ligurian Tethys (Fig. 11). Moreover, in the Flyschs domain and in the "northernmost Rif-Tell units", the former sedimentary cover of the Maghrebian Tethys, the Eocene-Oligocene transition corresponds to a change from carbonate to clastic facies but without any angular unconformity (Wildi, 1983). The stillexisting Maghrebian Tethys after $35 \mathrm{Ma}$ is also consistent with the fact that the subduction recorded in the Temsamane Massif (under-thrust segment of the African margin) and likely in the Oran area had begun as a subduction within the Ketama-Oran Basin. We consequently propose that from $67 \mathrm{Ma}$ to $35 \mathrm{Ma}$, the oblique convergence between Africa and Iberia was accommodated (1) by the progressive closure of the West Ligurian Tethys (see also Michard et al., 2002) and (2) by the subduction of the western part of the African margin (Temsamane and Oran units) below the Ketama-Flyschs oceanic basin.

\subsection{The Oligocene-Miocene (r)evolution (Figs. 12-14)}

The Eocene-Oligocene transition ( $35 \mathrm{Ma}$ ) is marked by a new change in the kinematics of the convergence between Africa and Eurasia, which got back to its previous N-S trend. The onset of a new subduction on the eastern and southern sides of $\mathrm{AlKaPeCa}$ involving both East Ligurian and Maghrebian Tethys (i.e. the "Flyschs Basin") accommodated the convergence (Fig. 12). In parallel, the two previously active subduction zones (i.e. the West Ligurian and Ketama-Oran subductions) were abandoned. Remnants of HP-LT metamorphic rocks exhumed during the closure of the West Ligurian oceanic domain and associated ophiolitic rocks are cropping out in Corsica (Vitale-Brovarone et al., 2013) and in the Internal Betics (in the Alpujarrides: Platt et al., 2005; in the Nevado-Filabres Complex: Puga et al., 2011). 


\subsubsection{Sedimentary record of the Oligocene geodynamic change}

In the Maghrebian and East Ligurian Tethys, the change of the geodynamic context is recorded by the transition from a passive-margin-bounded basin to a compressional foreland basin (see review by Guerrera and Martín-Martín, 2014). The Oligocene to Early Miocene sedimentary infill of this basin comprises immature turbiditic sandstones in the north ("Flysch gréso-micacé" of the French authors; Mauretanian Domain) and the mature to ultra-mature sandstones of the famous Numidian Formation to the south (Massylian Domain; see about the "Numidian question", the review by Thomas et al., 2010). It is established that the Mauretanian Domain was sourced from the north, i.e. AlKaPeCa, and the Massylian from the south, i.e. Africa. Mixed sedimentation exists in-between these two domains (Belayouni et al., 2013 and references therein).

The links between the former oceanic units (Mauretanian/ Massylian) and the coeval more external deposits are not straightforward. In the Tunisian part of the African margin (Tunisian Atlas), the wide Fortuna delta system development was contemporaneous with the Numidian flysch deposition; and it represents one of its main sources (Yaich et al., 2000). The Numidian Formation extends in Eastern Algeria with similar characteristics (Vila, 1980). From the Greater Kabylie westwards, due to the structural complexity, the presence of intermediate facies between the Lower Miocene rocks cropping out in the foredeep and tectonic windows and the Numidian is not so clear. In the Western Tell, Oligo-Miocene deposits are found in two distinct structural positions. On the one hand, they rest unconformably over the allochthonous external units as it is the case for the wedge-top Chelif Basin (Neurdin-Trescartes, 1992; Roure et al., 2012; on the southern nappes of Fig. 3B) or for small lower Miocene basins (Courme-Rault, 1984). On the other hand, they are involved in thrust-sheets whose palaeogeographic origins are difficult to precisely track. In the latter case, the Oligo-Miocene formations should represent transitional or lateral facies of the Numidian. In the Western Tell, Fenet (1975) and Guardia (1975) suggest that the so-called "Oligo-Miocene" unit could correspond to the former cover of the "Senonian" units (forming the main body of the higher Rif-Tell nappes) and could consequently represent such lateral and transitional facies. In the Eastern Rif, it is worth noting that conformable Numidian-like facies are known at the top of the higher TellRif nappes, e.g. in the Aknoul (Leblanc and Feinberg, 1982), Tsoul and Ouezzane units.

\subsubsection{Extensional deformation in AlKaPeCa, far effects in the foreland}

The onset of the northward to northwestward subduction of the ELT and Maghrebian Tethys below Corsica-Sardinia and $\mathrm{AlKaPeCa}$ was associated with a considerable slab retreat, leading to the formation of back-arc basin (Réhault et al., 1984). The net result was the translation/rotation of these two micro-continents and the coeval opening of the West Mediterranean basins either made of stretched continental or oceanic crust (Figs. 12-14). After the counter-clockwise rotation of the Corsica-Sardinia that opened the Liguro-
Provençal Basin, the Algerian Basin resulted from the dislocation of the Alboran-Kabylie following N-S to NWSE trends (Arab et al., 2016; Booth-Rea et al., 2007; Leprêtre et al., 2013; Mauffret et al., 2004 and references therein).

Sedimentary record and geochronological data evidence the onset of a generalized Upper Oligocene/Lower Miocene rifting. The widespread extension is witnessed on the upper plate involved in the subduction process. It was firstly recognized on Kabylie basement through the deposition of the syn-rift "Oligo-Miocene Kabyle" dated from Late Oligocene to Burdigalian (Aïte and Gélard, 1997; Géry et al., 1981). These ages of rifting agree with seismic interpretations by Leprêtre et al. (2013) and Arab et al. (2016) for areas along the Algerian margin where tilted blocks are preserved. Recent seismic studies in the West Alboran Basin have also evidenced this large-scale extensional event. Based on seismic analysis coupled with onshore data, Suades (2016) documented this extensional event in the northern Alboran Basin and onshore southern Spain (Malaga area). Do Couto et al. (2016) proposed new seismic analysis with revised calibration for the stratigraphy of the West Alboran Basin and found a similar timing with major N-S extension during the Late OligoceneEarly Miocene period.

Other evidences from the widespread extensional regime affecting the future western Mediterranean at that time come from geochronological and metamorphic studies. They revealed large-scale extension associated with HT metamorphism (among others Fernandez et al., 2016; Negro et al., 2006; Platt and Whitehouse, 1999) and formation of crustal scale detachements (Augier et al., 2005; Caby et al., 2001; Crespo-Blanc et al., 1994; Jabaloy et al., 1993; Platt et al., 2005) producing deep unroofing during the Late OligoceneEarly Miocene, within the AlKaPeCa domain (Bruguier et al., 2009; Michard et al., 2006; Monié et al., 1992; Monié et al., 1994; Platt et al., 2003). This Miocene signal shows diachronous stages between the "AlKa" and "PeCa" domains, being older for the Peloritani and Calabria than for Alboran and the Kabylie basement (Michard et al., 2006; Platt et al., 2013 for the Betics-Rif-Tell data; Heymes et al., 2010; Rossetti et al., 2004, 2010 for the Peloritani-Calabria data).

During the Oligocene and Early Miocene, in the foreland of the Tell-Rif, the Atlas system is also the site of an extensional regime or, at least, tectonic quiescence (Bracène and Frizon de Lamotte, 2002; Frizon de Lamotte et al., 2000). We discuss the meaning of this unexpected deformation on the lower plate in the discussion section (see Sect. 5.2).

\subsection{3 "Collision" and lateral slab tearing along the African margin}

The onset of Oligocene subduction along the southeastern side of AlKaPeCa led to the development of an accretionary prism involving the sedimentary cover of the Maghrebian and East Ligurian Tethys. The docking of the Kabylie against the African margin occurred at $17 \mathrm{Ma}$ (Late Burdigalian) for the oldest as witnessed by the Collo granite emplacement crosscutting both the Lesser Kabylie and the African basement (Abbassene et al., 2016; Aïssa et al., 1998, 1999; Chazot et al., 2017). This result is in line with the stratigraphic ages of the youngest Miocene sediments sealing the frontal deformation of the Tell nappes in central and eastern Algeria (Caire, 1957; 


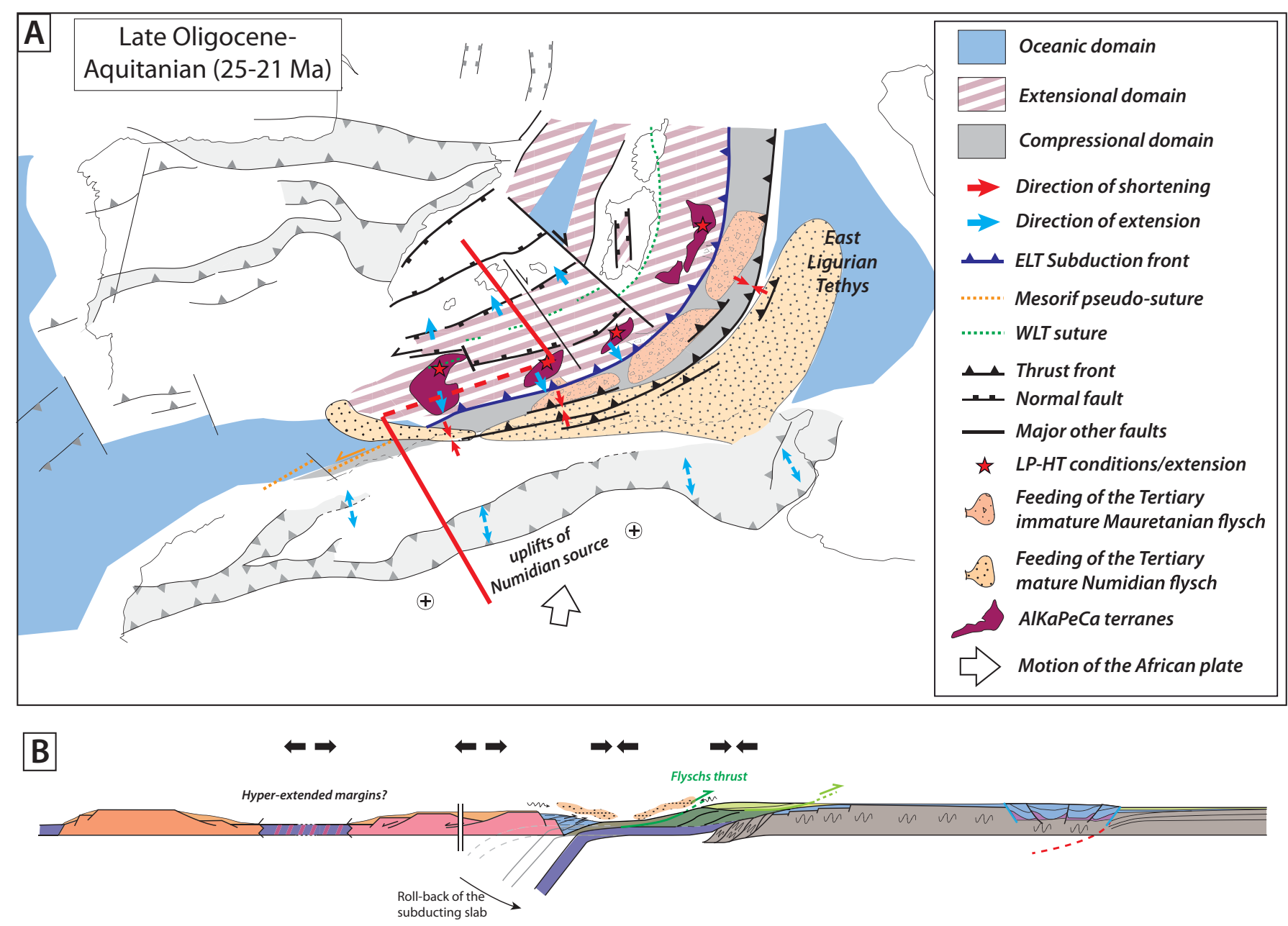

Fig. 13. Paleogeographic reconstruction for the Late Oligocene-Early Miocene (25-21 Ma). (b) Simplified cross-section of the closing Maghrebian Basin and West Mediterranean opening. Same legends than in Figure 10b.

Courme-Rault, 1984; Mattauer, 1958; Polvêche, 1960; Vila, 1980; Wildi, 1983). This event marked the closure of the central part of the Maghrebian Tethys and the onset of the delamination of the sub-continental African mantle (Roure et al., 2012). In fact, the initial orogen propagated outward with early thrusting of the Kabylie-Flysch domains on top of the external domain during the Late Burdigalian, whereas the frontal parts of the nappes glided in the Miocene foredeep up to Langhian times in central and eastern Algeria (Courme-Rault, 1984). The consequence of this closure was also a change in the structural style. From that time onward, the shortening has been accommodated through both frontal accretion and tectonic underplating (used hereafter in the sense of Platt, 1986, 1988, for accretion prisms, in coincidence with deep duplexing at the base of accretion prism), through the activation of different décollement levels, from the thinned African crust to the sedimentary levels upward.

Under North Africa margin, the southward mantle delamination (Roure et al., 2012) allowed propagation of the deformation toward the foreland. However, very rapidly slab rupture occurred below the African margin and it facilitated its tearing in two different directions: towards the present-day Calabrian Arc, creating the Tyrrhenian Basin, and towards the present-day Gibraltar Arc, creating the Algerian Basin (Jolivet et al., 2008; Lonergan and White, 1997; Mauffret et al., 2004; Spakman and Wortel, 2004; Van Hinsbergen et al., 2014).

The eastward tearing of the African slab toward Sicily, Calabria and southern Apennines is well described by different authors (see a review in Carminati et al., 2012). After a swing of the tectonic transport direction, it roughly corresponds to the continuation of the progressive subduction of the eastern part of the Maghebian-Ligurian Tethys and its African continental margin. It is characterized by the continuing eastward incorporation of more and more external units in the orogenic wedge and the coeval migration of the foredeep (Casero, 2004; Casero and Roure, 1994; Di Paolo et al., 2014). On the Mediterranean side of the system (Tyrrhenian Sea), a parallel eastward migration of the back-arc basin is observed at the rear of the Calabrian Arc (among others Faccenna et al., 2004).

The westward propagation of the slab tearing allowed the opening of the West Algerian Basin from Burdigalian to Tortonian times, in relationship with the westward motion of the Alboran block, bearing the already formed West Alboran 


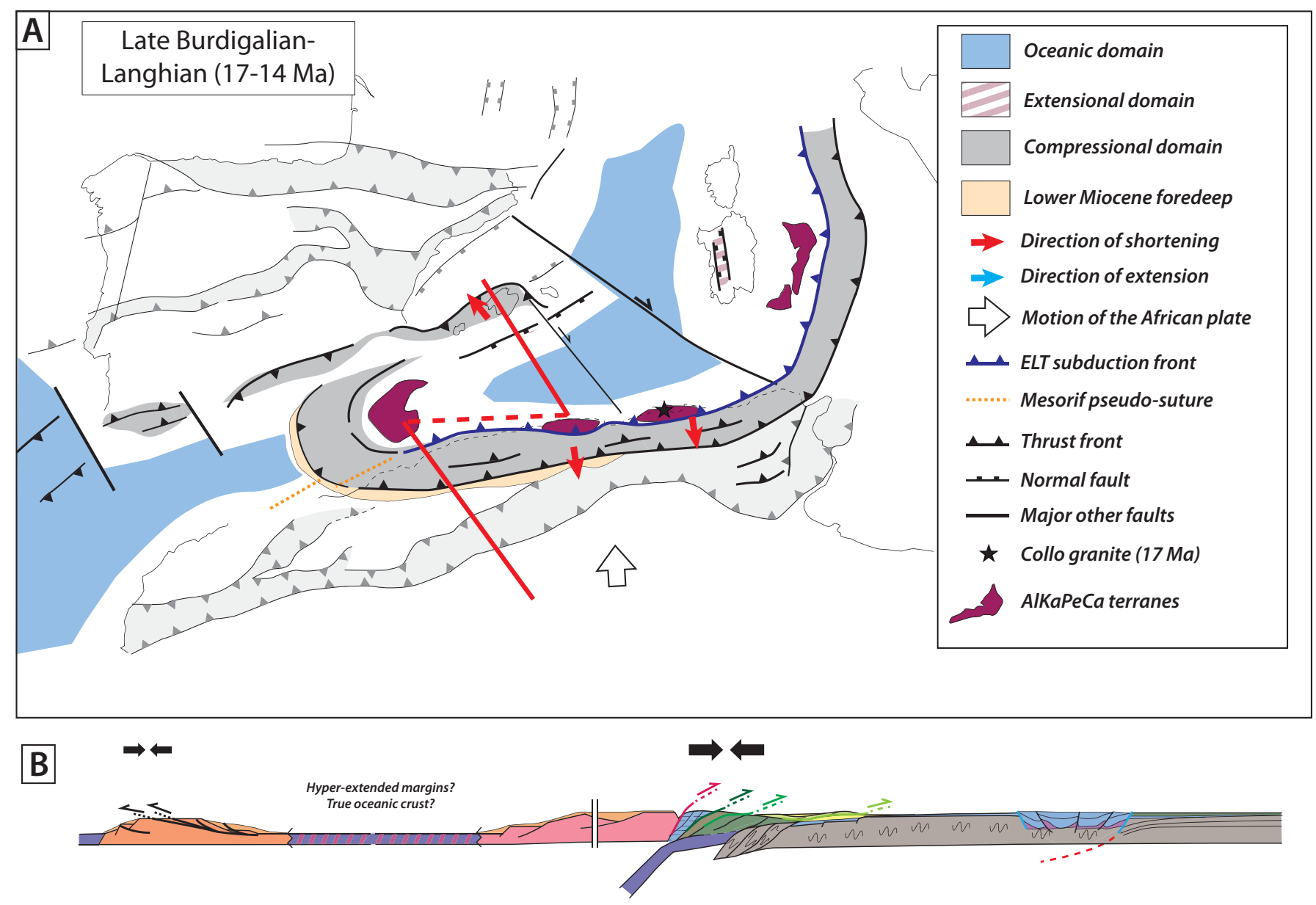

Fig. 14. (a) Paleogeographic reconstruction for the Late Burdigalian-Langhian (17-14 Ma). (b) Simplified cross-section of the West Mediterranean. Same legends than in Figure $10 \mathrm{~b}$.

Basin (Booth-Rea et al., 2007; Do Couto et al., 2016; Medaouri et al., 2014; Spakman et al., 2018). The precise kinematics of the West Algerian Basin opening remains unclear because of the complexity of the associated processes. The migration of the Alboran block is nicely recorded onshore within the Miocene foredeep, fossilizing the displacement of the higher Tell-Rif nappes (Fig. 4). The age of the Miocene sediments evidence a migration that began in the Middle-Late Serravallian in the Oran area, in the Late Tortonian in the central-eastern onshore foreland Rif Basin and even to the Pliocene in the Western Rif (Feinberg, 1986). An important point must be underlined here regarding the position of the Alboran block before the westward migration. The area showing the oldest sediments post-dating the Kabylie docking can be identified eastward up to Mostaganem (Fig. 2). This gives an approximate westernmost location for the western boundary of the Alboran block before its migration. This proposal is quite close to the proposal by Domzig et al. (2006) based on seismic and bathymetry data.

The coeval exhumation of the metamorphic rocks of the EMM during the Alboran block migration is a very important feature of the Rif-western Tell segment of the system. We propose a two-steps scenario for the exhumation, which globally occurred in a context of left-lateral movement
(Booth-Rea et al., 2012; Frizon de Lamotte and Leikine, 1985, 1987; Frizon de Lamotte et al., 1991; Jabaloy-Sánchez et al., 2015; Negro et al., 2007, 2008). In our view, after the subduction stage (Fig. 6b), an imbrication stage with underplating developed within the accretion prism (Fig. 6c). It resulted in a doming that created the slope responsible for the detachment and the southward gliding of the higher Tell-Rif nappes. The age of the youngest sediments of the foreland basin just below the nappes gets younger to the west-southwest: from Early-Middle Miocene in the Tell to Upper Miocene in the Central Rif and Pliocene in the Western Rif. In the western Tell, this early doming stage is responsible for the Lower Miocene infill of the Chelif Basin in a piggyback configuration on top of the nappes. The second stage, in continuity or partially synchronous with the former one, allowed the development of Upper Miocene wedge-top basins like the second Miocene sequence of the Chelif Basin and the Neogene Basins Central-Eastern Rif (Figs. 7 and 8). Deposition within these basins was controlled by extenseional deformation (Roure et al., 2012; Samaka et al., 1997; Figs. 3, 7 and 8) associated to strike-slip faulting. Here again, the Rif basins (Tortonian-Messinian) are younger than the West Algerian ones (Late Langhian/Serravallian-Tortonian; Fig. 4). 


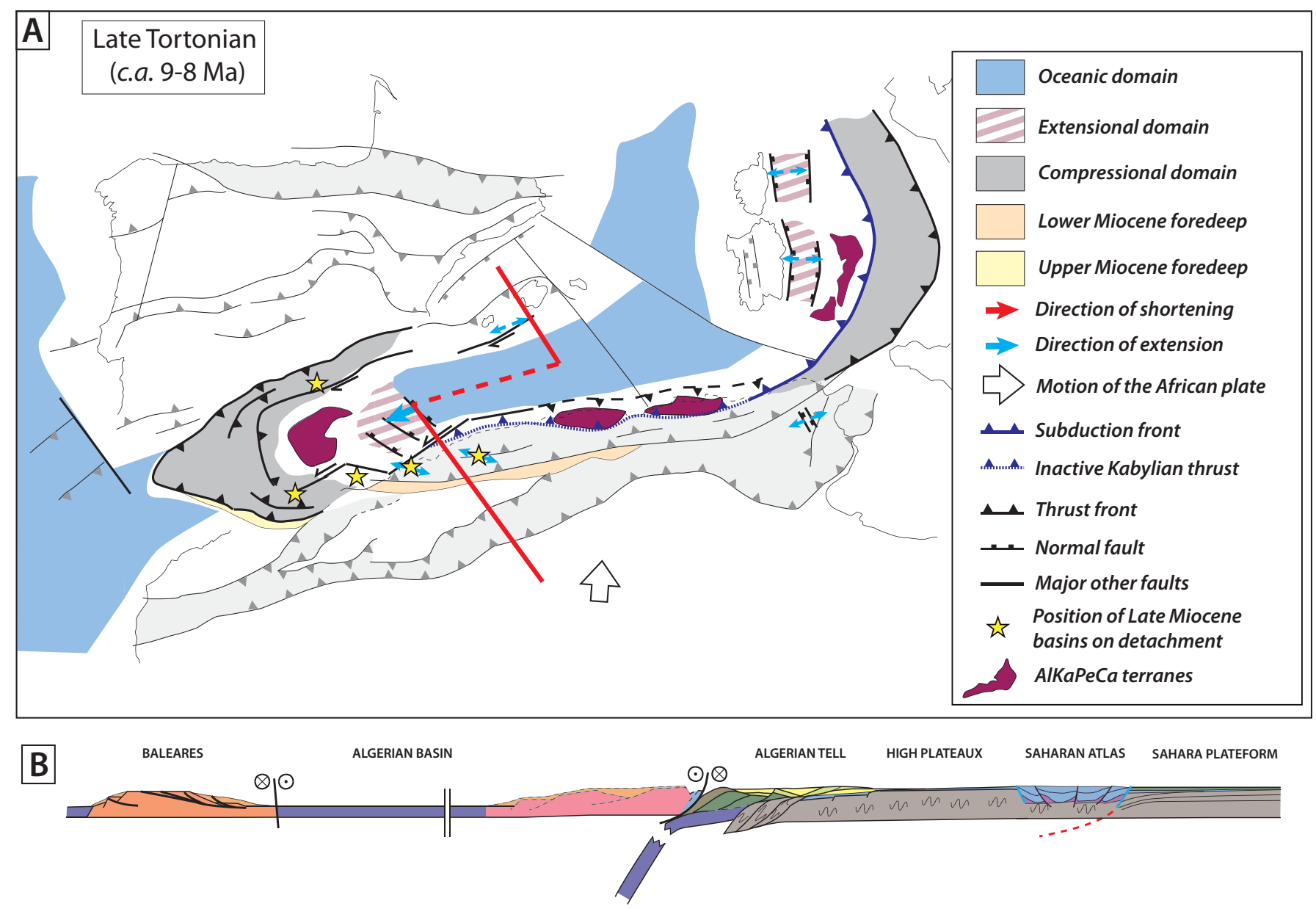

Fig. 15. (a) Paleogeographic reconstruction for the Late Tortonian (9-8 Ma). (b) Simplified cross-section of the West Mediterranean. Same legends than in Figure 10b.

In summary, the Oligo-Miocene period corresponds to the closure of the Maghrebian Tethys and the coeval opening of the West Mediterranean Basin (Figs. 10-15). A very important point, which is not taken into account in most of the kinematic models, is that along the North-African margin, the deformation mechanism is not the push linked to AlKaPeCa motion but the pull linked to slab retreat in a first time, and the delamination of the African sub-continental mantle in a second time (Roure et al., 2012). It is the reason why the deformation can develop at distance from the $\mathrm{AlKaPeCa}$ front. As a matter of fact, the present West Mediterranean slab is disconnected from the suture between the Alboran domain and the African margin (de Lis Mancilla et al., 2015; Palomeras et al., 2014; Thurner et al., 2014, and references therein). The westward retreat of the slab explains why the External Rif is moving more rapidly in the west than in the east (Pérouse et al., 2010; Figs. 14-15).

\subsection{The Late Tortonian-Pliocene-to-Present (r) evolution}

Currently, the direction of convergence between Africa and Eurasia is NW-SE (Nocquet and Calais [2004] and references therein). This oblique convergence is accommodated in the
Tellian onshore by reverse motion on NE-SW trending faults and by right-lateral strike-slip motion on E-W trending faults as indicated by earthquakes focal mechanisms and by tectonic studies (Meghraoui et al., 1996; Rabaute and Chamot-Rooke, 2014). All these faults are inherited from the previous geodynamic history.

In the Tell offshore, high resolution seismic data reveal a set of young or still active fault-related folds at the toe of the Central and Eastern Algerian margin interpreted as the trace of a possible subduction initiation of the young Algerian Basin beneath Africa (Déverchère et al., 2005; Domzig et al., 2006; Kherroubi et al., 2009). If correct, it should represent the inception of a new slab reversal after the one occurring at $35 \mathrm{Ma}$ after the closure of the western Ligurian Tethys. The age of this tectonic inversion of the Algerian margin is suggested by Arab et al. (2016) to have initiated as soon as the Late Tortonian. We show below that this is consistent with the generalized resumption of compression at the scale of the northern Maghreb and even in South Spain at this age.

In Eastern Algeria and Tunisia, the tectonic regime remains consistent with the eastward escape controlled by the Tyrrhenian slab (Rabaute and Chamot-Rooke, 2014). In Western Algeria, on the contrary, the new tectonic regime strongly contrasts with the previous one dominated by leftlateral movements and the westward translation of the Alboran 
domain (Fig. 16). As soon as the Alboran Domain had made its WSW drifting, the Africa-Eurasia convergence imposed NNWSSE compressional deformation. Following Thomas (1985), the transition between the two regimes should have occurred around $8 \mathrm{Ma}$, during the Tortonian. It is also evidenced in the Betics (e.g. Do Couto et al., 2014; Janowski et al., 2017). Paleomagnetic measurements performed on volcanic rocks younger than $8 \mathrm{Ma}$ show that they suffered systematic clockwise vertical axis rotations in agreement with right-lateral movement along E-W faults (Derder et al., 2011, 2013). Following Morel and Meghraoui (1996), the deformation observed in the Tell is an element of a longer right-lateral deformation zone that they called GALTEL (Gorringe-Alboran-Tell) (Fig. 16). They interpret this 50 to $100 \mathrm{~km}$ wide zone as the present diffuse plate boundary between Africa and Europe.

In fact, the right lateral movement is well documented along the Tunisian and Algerian margin up to the Yussuf Fault Zone (Fig. 16). South and west of this limit, the recent and active deformation remains under the control of the westward retreat of the delaminated sub-continental mantle (Pérouse et al., 2010). This westward translation is accommodated in the Central Rif by vertical axis counterclockwise rotation measured in the Upper Miocene wedge-top basins (Cifelli et al., 2008) and by development of N-S extensional faults (Lafosse et al., 2017). The NE-SW left-lateral Nekor Fault, inherited from the Lower Jurassic rifting (Figs. 2 and 7A), is a major element of this system and marks the southern limit of the domain affected by the westward movement.

\section{Discussion}

The review of the evolution of the Tell-Rif system in the frame of the West Mediterranean realm allows us highlighting some general questions. Since the initial Pangea configuration in the early Mesozoic, the history can be described as a succession of extensional phases with high coupling (e.g. during Jurassic described in Sect. 3.1), leading subsequently to major decoupling between the different plates (Fig. 5a and b showing the extensional coupling and the independent motions from Late Jurassic onwards, respectively). The individualization between Iberia, Eurasia, AlKaPeCa and Africa plates reached its climax during the Early Cretaceous. Since the Late Cretaceous, the convergence began and progressively led to the current configuration. This convergence was not steady state but occurred through successive phases of coupling/ decoupling between the plates.

The first aim of this discussion is to better define how the Tell-Rif system can be integrated in the regional kinematic scenario. This clarification helps understanding the important mechanical couplings that existed during the Cenozoic stages. In a second time, we will attempt bringing an explanation for the strong non-cylindrical behavior of the Tell-Rif belt. We will emphasize the respective role of the structural inheritance on one hand and specific Cenozoic kinematics on the other hand.

\subsection{Major tectonic events and kinematic reorganizations in the Tethys realm}

After the first short compressional event ("Santonian Event”; e.g. Guiraud et al., 1987 for the Africa plate), at the onset of Eurasia-Africa convergence, the movement of Africa relative to Eurasia continued up to the Middle Eocene without major visible compressional structures. During that period, the poor mechanical coupling between the plates enabled subduction to completely accommodate the convergence. The location and the vergence of this (these) subduction(s) remain(s) currently the matter of debates. Some authors (Faccenna et al., 2014; Jolivet and Faccenna, 2000; Lacombe and Jolivet, 2005; Stampfli and Marchant, 1997) place a single and permanent west/northwest-verging subduction east and south of AlKaPeca. This hypothesis minimizes or ignores the existence of a western Ligurian Tethys. Besides, this hypothesis copes with two difficulties: (1) the absence of tectonic activity along the $\mathrm{AlKaPeCa}$ east and south margin (the "Dorsale Calcaire") up to the end of the Eocene and (2) the presence of HP-LT metamorphic rocks within AlKaPeCa, which is difficult to explain if this domain always remained in the same upper plate position. For these reasons, we favor another hypothesis suggesting that the Africa-Eurasia convergence was firstly accommodated along the eastward subduction of the WLT, which would simply represent the western continuation of the Alpine subduction (Figs. 10 and 11). Thus, by the end of this first collision, $\mathrm{AlKaPeCa}$ may have incorporated pieces of the former lower plate, even HP units that will be exhumed during the West Mediterranean opening. The remnants of the WLT subduction are scarce but well described (located as blue stars in our palaeogeographic proposal in Fig. 11). They are mainly present within the Betics (Li and Massonne, 2018; Platt et al., 2005; Puga et al., 1999), in Alpine Corsica (Vitale-Brovarone et al., 2013) and possibly also in Calabria (Heymes et al., 2010; Rossetti et al., 2004) and East Algeria (Bruguier et al., 2017). Regarding the metamorphic record, the WLT hypothesis nonetheless suffers from the same limits as the "no-WLT" hypothesis, namely (1) the poor representation of HP-LT and other remnants from this oceanic domain which makes difficult the vergence interpretation of the general structures and (2) the lack of consensus on the age of the HP-LT event(s).

\subsubsection{The Middle-Late Eocene tectonic crisis}

The Middle-Late Eocene period is known as a period of major kinematic reorganization with a strong coupling between Africa and Eurasia plates as evidenced by far-field compressional stress widely distributed in the two major plates as well as in intermediate plates like Iberia (Bergerat, 1985; Guiraud et al., 2005). More precisely, it corresponds to an orogenic climax in the Pyrenees (Vergés and García-Senz, 2001) (the concept of Pyrenean phase), the Iberian Chain (Guimerá et al., 2004), the Catalan Coastal range (LópezBlanco et al., 2000) and in Southern Portugal (Algarve region: Ramos et al., 2016, Ramos et al., 2017a). Mirroring the Iberian intra-plate deformations, North Africa also recorded a strong middle-upper Eocene intraplate compressional event, present at the scale of the whole Atlas belt (the concept of "Atlas event" [Frizon de Lamotte et al., 2000, 2009, 2011]).

In the Tell-Rif, the Middle-Late Eocene tectonic crisis was often minored, suggesting that the convergence was mainly accommodated in intra-plate settings (Frizon de Lamotte et al., 2000). However, we have presented some evidence (see Sects. 3.2 and 4.1), showing that the outer part of the external Tell-Rif 


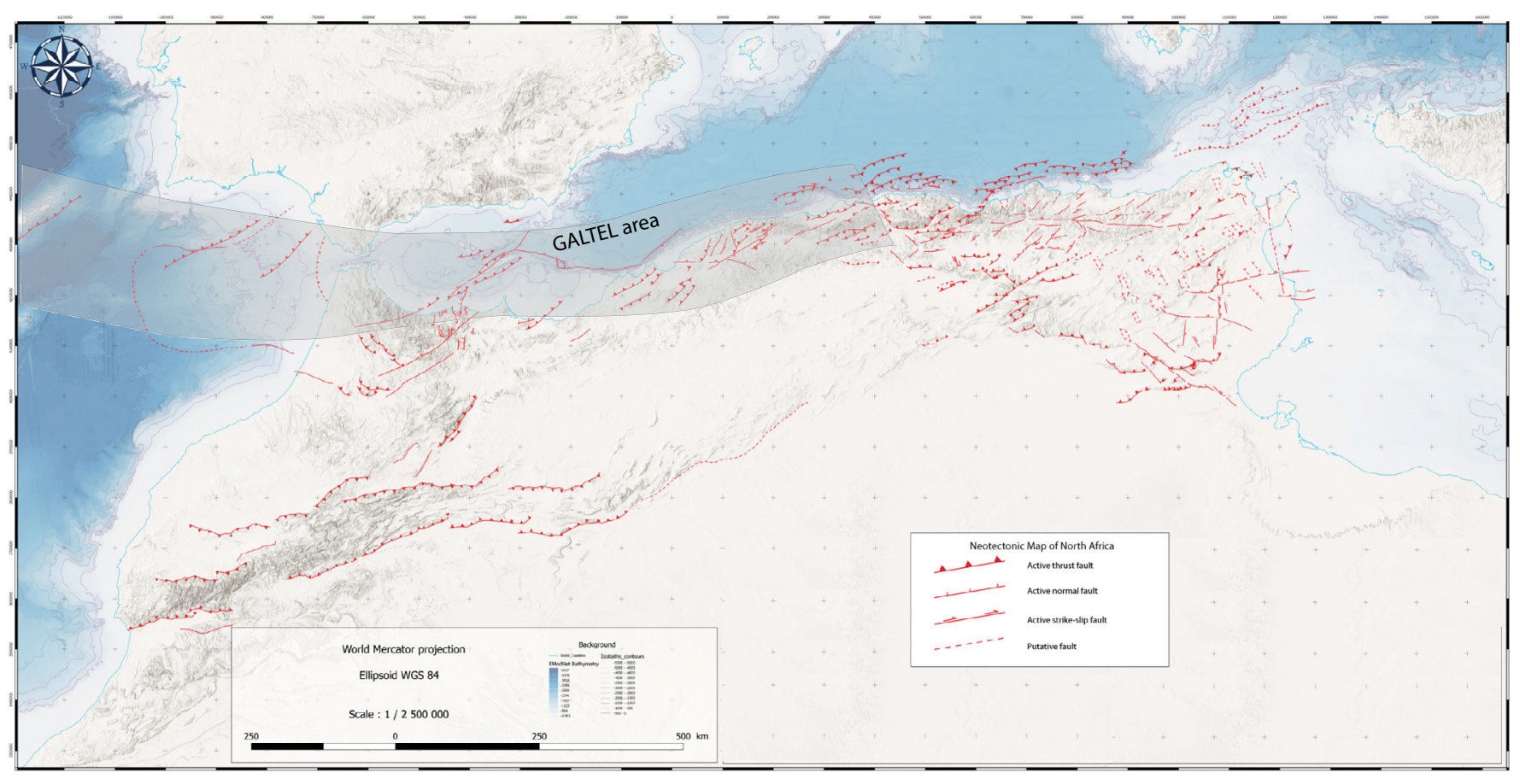

Fig. 16. Neotectonic map of Northwest Africa. This map was built using the following studies: Arab et al. (2016), Cadet et al. (2004), Domzig (2006), Meghraoui et al. (1996), Rabaute and Chamot-Rooke (2014), Lafosse et al. (2017) and Yelles et al. (2009). GALTEL abbreviation is for Gorringe-Alboran-Tell after Morel and Meghraoui (1996).

underwent significant deformation during Paleogene times. More importantly and according to Negro et al. (2007, 2008), a fossil "subduction" acted along the African margin, allowing the Temsamane Massif (Eastern Rif) to reach MP-LT metamorphic conditions during at least the Early Oligocene and probably earlier. This fossil "subduction" of the African margin can be followed eastward up to the western Tell (Michard et al., 2006, 2014). Therefore, the Paleogene deformation was important along the former African margin, although not homogeneously distributed. The reasons of this peculiar distribution are discussed just below.

From the Rosenbaum et al. (2002) reference, the rotation pole of Africa relative to Europe stayed within the [28.9-36.7 ${ }^{\circ}$ $\mathrm{N} /[19.2-15.5]^{\circ} \mathrm{W}$ area from 75 to $35 \mathrm{Ma}$. That means a rotation pole located close to north Morocco present-day coastline, in the Central Atlantic Ocean. From this pole, the absorbed shortening along the Africa-Europe boundary was thus progressively increasing toward the east during this period. On fixed African points with respect to stable Europe, Rosenbaum et al. (2002) estimated convergence rates ranging from $5 \pm 1 \mathrm{~km} . \mathrm{Myr}^{-1}$ in Morocco to $10 \pm 1 \mathrm{~km} . \mathrm{Myr}^{-1}$ in Sicily for the Eocene period. During this convergence period and in the eastern regions of the study area, we agree that the convergence was absorbed by intra-plate deformation and along the Ligurian subduction front, here considered to follow the western/southwestern boundary of $\mathrm{AlKaPeCa}$. To the west, along the Iberia/Africa plate boundary we have to integrate a complex kinematic configuration in which the Ligurian subduction front disappears westwards and the shortening becomes distributed along minor to intermediate compressional structures including: incipient subduction in the Rif and Oran basins and inverted former extensional structures
(Gorringe, Algarve, Middle Atlas, High Atlas). The complexity of this area is on one hand, inherited from the Mesozoic rifting stages (Fig. 5), and on the other hand related to the Africa plate motion from the Late Cretaceous to the MiddleLate Eocene (Fig. 9). An interesting point is the fact that in spite of the overall shortening processes during this preOligocene phase, the sedimentary cover of the Maghrebian Tethys itself (Flyschs domain) remained almost unaffected, which implies to behave as a rigid domain, the convergence being accomodated elsewhere.

The Eocene plate configuration of Northwest Africa (Fig. 11) can be compared to extensional or compressional zones in a triangle configuration (either opening or closing, respectively). The example of the North Atlantic northern branch, though being an extensional example, provides such a configuration. Its rotation pole is localized within north Siberia (Gaina et al., 2002). The oceanic ridge ends northward with the Gakkel Ridge (Rowley and Lottes, 1988; Fig. 17), before being relayed onshore by the numerous normal faults of the Ust-Lena Rift. In this extensional case, one can see a single "fault" zone concentrating most of the extension at the ridge location, whereas approaching the rotation pole with decreasing linear speed, the deformation becomes a lot more diffused, distributed over an array of minor normal faults over a wide area. Furthermore, the extension turns into compression right after the pole (Fig. 17). In the case studied here, the estimates of the Tunisian convergence rate is quite low $(10 \pm 1 \mathrm{~km}$. $\mathrm{Myr}^{-1}$ ) but could be enough to sustain a very slow subduction. Compared to the Tunisian rate, the North Morocco convergence rate is extremely low $\left(5 \pm 1 \mathrm{~km} . \mathrm{Myr}^{-1}\right)$ and could hardly sustain a continuous subduction (e.g. Hall et al., 2003 for minimum convergence rate avoiding thermal re-equilibration). 


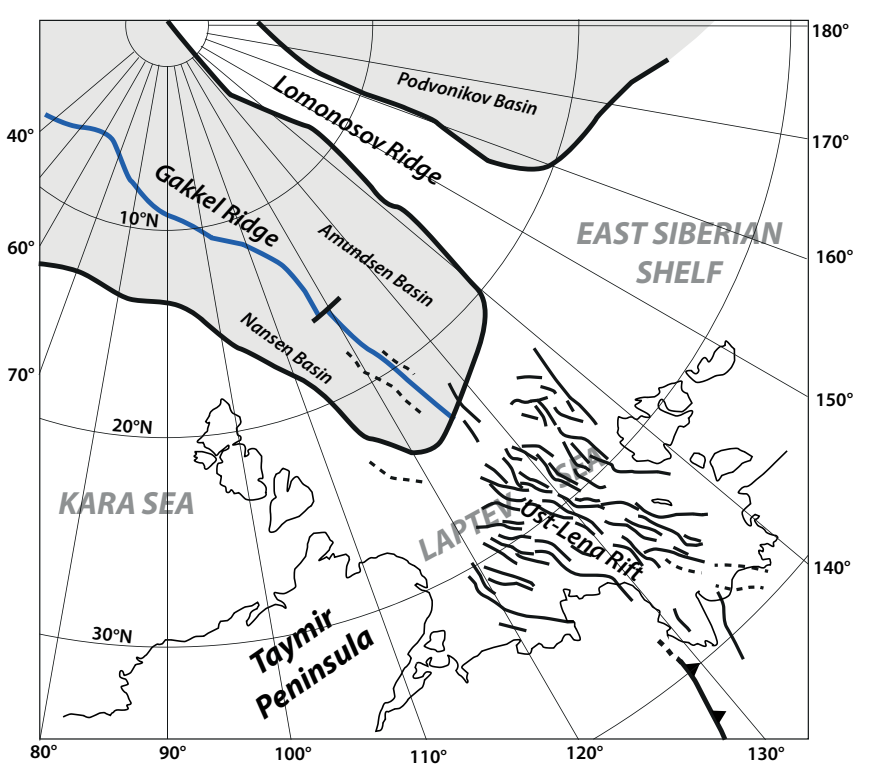

Fig. 17. Structural map of the Arctic Ocean, focused on the Gakkel ridge that ends the North Atlantic ridge (after Dobretsov et al., 2013). Pale grey areas represent the oceanic domains. The ridge is relayed through the Ust-Lena Rift and the extension become diffuse before becoming compressive toward the SE after crossing the rotation pole.

In spite of considering an extreme case in terms of convergence rates, the western tip of the Tethys shows an example where accommodation is progressively changing from a typical subduction along the AlKaPeCa northern boundary to a diffuse and more distributed accommodation zone westward (Fig. 11c). The Gorringe Bank, Algarve Basin, Mesorif windows and subductions in the Ketama-Oran Basin are individual pieces of this triangle "accommodation zone".

\subsubsection{The Oligocene-Miocene reorganization}

After the consumption of the WLT, a second generation of "sutures" developed from the post-Eocene stages. This part of the history is better documented and corresponds to the subduction of the ELT and the Maghrebian Tethys below the drifted AlKaPeCa and Corsica-Sardinia blocks (Doglioni et al., 1999; Handy et al., 2010; Lacombe and Jolivet, 2005; Michard et al., 2002; see Figs. 13-15). An "oceanic" suture is recognized by the authors in the Flyschs domain, considered to represent the former cover of the Maghrebian and East Ligurian Tethys (Bouillin, 1979; Bouillin et al., 1977; DurandDelga et al., 2000; Gélard, 1979; Guerrera and Martín-Martín, 2014). The oceanic nature of this "suture" that preserves remnants of the former Maghrebian Tethys and ELT crusts is poorly evidenced through few basic rocks remnants within Sicily, the Rif and the Tell (Durand-Delga et al., 2000 and references therein). A distinctive aspect of this suture is the scarcity of HP/LT remnants associated to it.

The major event regarding the post-Eocene stages is the Oligocene to Early Miocene extensional phase. By its geographical extent and the amplitude of extension, it represents one of the two periods of strong mechanical coupling between the Africa and Europe/Iberia plates, together with the Middle-Late Eocene tectonic crisis. The end of the Middle-Late Eocene showed a compressive deformation at the scale of the future West Mediterranean at least from the Pyrenees to the Atlas belt (Fig. 11). The Oligocene-Early Miocene event either fossilized or reworked in extension many of the former compressional structures (among others, see for the Pyrenees: Fillon and van der Beek, 2012; Vergés and García-Senz, 2001; for the Catalan Range: Roca, 1994; for the Baleares: Etheve et al., 2016; Roca, 1994; for AlKaPeCa: Aïte and Gélard, 1997; Arab et al., 2016; Caby et al., 2001; Comas et al., 1999; Heymes et al., 2008, 2010; Rossetti et al., 2004, 2010; Saadallah and Caby, 1996; for the Atlas belt: Bracène and Frizon de Lamotte, 2002; Ghandriche, 1991; Khomsi et al., 2016; Muratet, 1991; Torbi and Gélard, 1994).

An interesting issue regarding the Oligocene-Early Miocene extension concerns the fact that both upper and lower plates underwent extension. As it is expected mainly for the upper plate, the question of their mechanical coupling remains crucial. Studies compiling field data (Heuret and Lallemand, 2005; Lallemand et al., 2005; Sdrolias and Müller, 2006) and laboratory experiments (Clark et al., 2008; Heuret et al., 2007) regarding back-arc extension pointed the importance of the slab dip to explain the occurrence of back-arc extension as a crucial parameter. The convergence rate seems poorly significant to influence the extensional regime at the rear of the subduction zone. Also, as revealed by kinematic reconstructions (Handy et al., 2010; Rosenbaum et al., 2002), this rate remained very low during the Late Oligocene-Early Miocene $\left(0.4-0.6\right.$ to $\left.1.2-1.4 \mathrm{~cm} . \mathrm{yr}^{-1}\right)$. Chamot-Rooke et al. (1999) considered very low convergence rates around few mm. $\mathrm{yr}^{-1}$ for the African plate relative to Europe, at odds with the southward trench migration, reaching up to $6 \mathrm{~cm} \cdot \mathrm{yr}^{-1}$. We must notice that the usual explanations for this quick retreat lies within the slab dynamics in the upper mantle (Faccenna et al., 2001). In this view, at the Late Eocene-Oligocene transition, the slab fell down by gravity in the upper mantle and given the poor Africa convergence rate, the only way to accommodate this was to produce intense extension with back-arc opening at the rear of the system. However, we have proposed in this work to consider two successive subducting domains during the Late CretaceousEocene period and then during the Oligocene-Miocene period, making this explanation unlikely. Although the driving force (s) required for triggering extension in our scenario remain(s) unknown, we suggest that mantle evolution of the AlKaPeCa terrane after the Eocene collision might have played a crucial role for the onset of slab retreat. One can imagine progressive delamination of the Eocene belt (Fig. 11) with associated crustal extension and enhanced trench migration toward the south.

\subsection{The Tell-Rif: a fundamentally non-cylindrical belt}

One of the most striking features, when looking at the structural organization of the Tell-Rif (Figs. 2 and 3), is the difference between the western and eastern segments. This difference, contrasting with the almost linear shape of the belt (Fig. 2), involves the occurrence or the absence of at least three parameters: (1) the existence of EMM, (2) the development of thick wedge-top Neogene basins and (3) the development of 
the Miocene foredeep in front of the belt. The coexistence of these three parameters coincides with the western segment (Rif and western Tell) whereas their absence is typical of the eastern segment from the Babor Massif to Tunisia (Eastern Tell) (Fig. 2).

Three main parameters allow understanding this contrasted evolution. The first one is the inherited Mesozoic palaeogeography leading to the direct overlap (i.e. without rigid blocks in between) of the Tell over the Eastern Algerian and Tunisian Atlas (Fig. 1). In western Algeria and Morocco, these rigid blocks ("Mesetas") represent structural highs with thin Meso-Cenozoic deposits, escaping deformation during the orogeny. In eastern Algeria and Tunisia, a permanent high, with long-lasting development of a carbonate platform ("Constantine Platform" [Vila, 1980], Fig. 5), existed during the Mesozoic but is currently integrated within the Tell and partly within the Atlas. The second point is the tectonic history: the accommodation of the convergence was different with a subduction involving the African margin in the western regions. The last point is the kinematic history. Contrary to the eastern segment, the western segment structure results not only from frontal displacements, AlKaPeCa colliding with Africa, but also from post-Burdigalian stages showing a westward lateral escape of the Alboran block (Fig. 4). These considerable movements explain why the Rif displays a particularly complex structure with a frontal wedge in its western part whereas a combination of compressive and strike-slip structures gives its structural complexity to the eastern Rif (Frizon de Lamotte and Leikine, 1985, 1987; Jabaloy-Sánchez et al., 2015).

The presence of the EMM, exhibiting HP-LT metamorphic type, is linked to the former development of a subduction involving the segment of the margin located between the Temsamane and Oran-Chelif areas (Figs. 2, 5B and 6). They are consequently restricted to these western zones. The exhumation of the EMM occurred during the Middle Miocene in the Rif when the orogenic prism incorporated them by underplating. The exhumation is not precisely dated yet in the Tell, but following the first appearance of EMM pebbles (Fenet, 1975), it would have occurred as early as the Serravallian up to the middle Tortonian (Thomas, 1985). As indicated above, the exhumation occurred in a context of leftlateral movements. It was related to the westward translation of the Alboran domain, dragged by the progressive westward detachment of the African sub-continental mantle (Pérouse et al., 2010; Roure et al., 2012). From a geographic point of view, the wedge-top basins grew close to the EMM, flanking them laterally (Chelif, Eastern Rif) or frontally (Central Rif) (Fig. 2). They result from lateral and frontal collapse during the late stages of the EMM exhumation (e.g. for the Temsamane Massif: Booth-Rea et al., 2012). In the eastern regions, the absence of subduction of the margin explains the absence of both EMM and wedge-top-basins.

The western Tell and Rif Miocene foredeeps present the typical characteristics of flexural basins, with outward progressing onlaps well-observed in the Hodna Basin, for instance (Bracène and Frizon de Lamotte, 2002). The absence of any foredeep in the eastern Tell (Fig. 2) is consequently a challenging issue. This classical configuration for a fold-thrust belt is not "lost" in the eastern segment, it is likely to have never existed (e.g. Vila, 1980). This segment is the most distinctive in the entire West Mediterranean, because in Sicily and in the Appenines also, one can see another well-developed foredeep basin, largely over-thrusted by former basinal units (see Roure et al., 2012 for a review).

In fold-and-thrust belts, the development of a foredeep results from the interactions between few parameters. For a given tectonic load, the lithosphere rigidity (Watts, 2001) and the surface processes (i.e. mass transfer by erosion and sedimentation) control an important part of the deformation style (i.e. Bonnet et al., 2007; Fillon et al., 2013; Malavieille and Konstantinovskaya, 2010; Mary et al., 2013; Simpson, 2006). The existence and efficiency of several décollement levels add complexity for the structural style of the prism (Malavieille, 2010; Sherkati et al., 2006). Given these parameters, the reduction of the available space to generate a foredeep can be achieved through different ways. On the one hand, the more important the lithosphere rigidity, the more the flexure will tend to be weak, resulting in a large foredeep but thin available space for deposition. On the other hand, two competing effects have to be considered for the surface processes. Erosion role is very effective within the orogenic hinterland but exerts a less significant role for the external foldand-thrust belt (Beaumont et al., 1992; Willett, 1999). On the contrary, syn-tectonic sedimentation plays a first-order role in the deformation style of the fold-and-thrust belts (Fillon et al., 2013; Stockmal et al., 2007; Storti and McClay, 1995). It is worth noting that the mass transfer from hinterland to foreland can be achieved through tectonic unroofing of the hinterland, leading to the accumulation of gravity-driven nappes in the foreland. This mechanism was particularly efficient in the Rif and Western Tell: the duality between the northernmost TellRif units and the Tell-Rif higher nappes (Figs. 2 and 3).

From the map in Figure 2, the Tell-Rif foredeep extents from the Hodna Basin to the Gharb Basin at the western end of the system (Fig. 2). In between the Tell and the Rif, the foredeep is poorly developed north of the Gareb-Kebdana embayment (Fig. 2). Nonetheless, as a whole, the Tell-Rif foredeep is narrow and deep. This is indicative of a small effective elastic thickness of the lithosphere combined with a significant subsidence. The youth of the basement, which is Variscan in age, could explain the low value of the effective elastic thickness. The tectonic loading, responsible for the flexure, results from the duplexing observed in the EMM and subsequently from stacking, which led to the formation of the Tell-Rif external windows (Figs. 2 and 3 [Sects. a and b]). Therefore, the mechanism responsible for the flexure is the tectonic underplating of the African margin. The emplacement of the Tell-Rif higher nappes in the foredeep contributed to accentuate the subsidence. Our Rif and western Tell sections (Fig. 3A and B) illustrate the combination of these processes.

In the western Tell, the foredeep is Lower Miocene to Langhian (Fig. 4; Delteil, 1974; Roure et al., 2012), synchronous with the Lower Miocene infill of the Chelif Basin (Perrodon, 1957; Roure et al., 2012). At this stage, the Chelif developed as a piggy-back basin, in front of underplated basement slices of the EMM. In the Gareb-Kebdana Recess, the foredeep is limited to the so-called "Gareb-Kebdana Chaotic Unit” (Hervouët and De Luca, 1980; Hervouët, 1985) of Lower to Middle Tortonian age. The absence of Tell-Rif higher nappes in this segment of the belt is noteworthy. This is possibly one of the factors explaining the low subsidence of the 
foredeep. To the west, the foredeep is Upper Miocene (Upper Tortonian-Messinian) (Suter, 1980a, 1980b) and coeval to the development of the wedge-top collapse-basins of the central and eastern Rif (Fig. 4). This period partly corresponds to the second step of the Chelif Basin, combining lateral collapse and left lateral displacement. It appears consequently that the TellRif foredeep developed mostly on a slope perpendicular to the main movement. Its development occurred during two main steps (Late Burdigalian-Langhian and Upper TortonianMessinian, respectively), corresponding to two steps of Alboran lateral escape (Figs. 14 and 15). In between these two steps, the emplacement of the Gareb-Kebdana Chaotic Unit likely marks a period of rapid translation, coeval to the EW opening of the Algerian oceanic basin (Mauffret et al., 2004; Medaouri et al., 2014).

In summary, the development of a foredeep in front of the western Tell and Rif depends on the tectonic underplating, which led to the formation of the EMM and external tectonic windows, combined with a thin effective elastic thickness of the lithosphere. These two elements are lacking in the eastern Tell. On the one hand, there is no EMM nor external tectonic windows in this part of the belt (Fig. 2; Fig. 3, Sects. c and d). On the other hand, this region is out of the Variscan Front (see the postulated position of this front in Frizon de Lamotte et al. [2011], Fig. 10). The crust is consequently older (at least Panafrican) and we can expect a thicker effective elastic thickness of the lithosphere. If we look at the Late Oligocene configuration (Fig. 13), it is interesting to note the development of a wide basin (p.p. the Numidian Basin) at the junction between the Ligurian and Maghrebian Tethys. The basin, which covers not only the oceanic domain but also the African margin and a large part of the Atlas domain (Fig. 13), develops at the front of the southward moving AlKaPeCa. Such a wide basin implied an important rigidity of the lithosphere at this place. The basin is subsequently involved in a progressive deformation leading to its dismembering. During the formation of the orogenic prism, frontal imbrication dominated underplating as evidenced by the absence of tectonic culminations (Fig. 2; Fig. 3, Sects. c and d).

Finally, during the Upper Miocene the eastern Tell directly overlapped the Atlas belt, without barriers such as the "Mesetas" present in front of the western segments (Fig. 15). We know that the Atlas belt presents a very efficient Triassic salt décollement, which had likely reactivated the system. Therefore, the Atlas system absorbed the shortening by distributing and translating it southward without development of a foredeep in between. In addition, the reactivation of some basement highs thanks to efficient décollement layers in the Atlas (within the Triassic salt but also within the basement) could alter or prevent the deposition of a classical foredeep, as described by Catuneanu (2004) in the Karoo province or by Aschoff and Steel (2011) in the Sevier-Laramide foreland.

\section{Conclusion}

Classically, the Tell-Rif belt has been presented as an orogenic system developed since the end of the Eocene as the result of the slab roll-back of the Maghrebian Tethys lithosphere. The analysis of the rich geological (stratigraphical, tectonic, metamorphic) records improves this picture and allows us to propose a more comprehensive integration in the West Mediterranean geodynamics through a revised structural map for the belt and new cross-sections (Figs. 2 and 3). Conversely, a better knowledge of the Tell-Rif may lead to an enhanced understanding of the geodynamic mechanisms active in the West Mediterranean.

Our main goal was to explain the non-cylindrical behavior of the belt. At least two first-order parameters appeared significant. The structural inheritance is a first key point. The southern Tethys paleo-margin, currently included in the TellRif external zones, was a Middle-Late Jurassic E-W highly oblique margin reworking Early-Middle Jurassic rifted basins oblique (i.e. NE-SW) to the main eastward motions of Africa (Fig. 5), themselves inherited from Variscan trends. The Atlas orogenic system preserves some of them in the form of slightly inverted intracontinental belts (Fig. 1). The other basins, more distal and partly oceanic, were strongly inverted and currently are integrated in the western Tell and Rif external zones. Their closure gave rise to the development of secondary subductions involving only the western part of the margin (Figs. 10 and 11).

The subsequent kinematic evolution led to rework this inherited structural frame. Indeed, the EMM occurrence together with the western Tell-Rif foredeep development resulted from the Jurassic frame and the Eocene kinematics allowing the development of subduction of the African paleomargin in the part of the system located west of the West Ligurian Tethys subduction front (Fig. 11). The Miocene kinematics of the Alboran block is also essential in understanding the time lag in the foredeep age (here the oldest age for the emplacement of the nappes) between the western Tell and the Rif, from the Late Burdigalian to the Late Tortonian, respectively (Figs. 12-14).

The Africa-Europe convergence led to the closure of the two branches of the Ligurian Tethys. During the Paleogene, the West Ligurian Tethys has been consumed through subduction (Fig. 10). Its subduction ended with the collision of the AlKaPeCa block with Iberia. In the Rif and the western Tell, the subduction of the African paleo-margin was still active. The peak of HP-LT metamorphism and deformation occurred during the Middle-Late Eocene (45 to $35 \mathrm{Ma}$ ). It corresponds to a major event at the scale of the whole belt and is correlated to a period of strong coupling between the Eurasian, Iberian and African plates with development of intra-continental belts (Fig. 11) and far-field compressional deformation.

The Eocene-Oligocene transition (35 Ma) marks a complete kinematic and geodynamic reorganization, the onset of a new cycle. This part of the history corresponds to the closure of the Maghrebian Tethys (Figs. 12-15). The slab roll-back mechanism, associated with back-arc extension, explains the asymmetry of the belt, characterized by a single vergence for each transect (Fig. 3). The progressive accretion of sedimentary slices led to the building of a classical tectonic wedge exposed in the eastern regions. In the western regions, the underplating of metamorphic rocks (inherited from the Middle-Late Eocene event), the coeval development of wedge-top basins and the preeminence of lateral movements led to a more complex configuration. A new kinematic change occurred at $8 \mathrm{Ma}$. It is particularly spectacular in Western Tell with a switch from left-lateral to right-lateral displacements along E-W faults (Fig. 16). 
Acknowledgements. This work has benefited from fruitful discussions with Jean-Loup Rubino, Jean-Claude Ringenbach, Charlotte Nielsen, François Guillocheau, Jacques Déverchère, Olivier Laurent, Jean-Christophe Bosset, Najib Zaghloul, Faouzyia Haissen, Philippe Razin, David Graindorge, Christian Gorini, Sami Khomsi, Jean-Marie Vila, Pierre Guardia, Laurent Jolivet, Adrien Romagny and Emmanuel Masini. We acknowledge the contribution of two master students: Naïm Célini (ENSEGID, Bordeaux) and Bernard Verbeken (Univ. Barcelona). We thank warmly A. Michard and F. Roure for their attentive reading of early versions of this manuscript. Careful advices by R. Augier and two anonymous reviewers are greatly acknowledged as they help improving this work.

\section{References}

Abbassene F, Chazot G, Bellon H, Bruguier O, Ouabadi A, Maury $\mathrm{RC}$, et al. 2016. A 17Ma onset for the post-collisional K-rich calcalkaline magmatism in the Maghrebides: evidence from Bougaroun (northeastern Algeria) and geodynamic implications. Tectonophysics 674: 114-134.

Agard P, Jolivet L, Goffé B. 2001. Tectonometamorphic evolution of the Schistes Lustres Complex; implications for the exhumation of HP and UHP rocks in the Western Alps. Bulletin de la Société Géologique de France 172(5): 617-636.

Aïssa D-E., Marignac C, Cheilletz A, Gasquet D. 1998. Géologie et métallogénie sommaire du massif de l'Edough (NE Algérie). Mémoires Du Service Géologique d'Algérie 9: 7-55.

Aïssa D-E., Marignac C, Cheilletz A, Gasquet D. 1999. Le Skarn à scheelite de Karezas (Annaba, Nord-Est Algérie): un skarn polycyclique d'âge Burdigalien. Bulletin Du Service Géologique de l'Algérie 10(1): 3-53.

Ait Ouali R. 1991. Le rifting des Monts des Ksour au Lias. Organisation du bassin, diagenèse des assises carbonatées, place dans les ouvertures mésozoiques au Maghreb. PhD Thesis Univ. STHB Alger, 1-298 pp.

Aïte MO, Gélard JP. 1997. Post-collisional palaeostresses in the Central Maghrebides (Great Kabylia, Algeria). Bulletin de La Societe Geologique de France 168(4): 423-436.

Alvarez W. 1974. Fragmentation of the Alpine orogenic belt by microplate dispersal. Nature 248: 309-314.

Andrieux J. 1971. La structure du Rif central: étude des relations entre la tectonique de compression et les nappes de glissement dans un tronçon de la chaîne alpine. Notes et Mémoires du Service Géologique 235. Rabat, Morocco: Service géologique du Maroc.

Arab M, Rabineau M, Déverchère J, Bracene R, Belhai D, Roure F, et al. 2016. Tectonostratigraphic evolution of the eastern Algerian margin and basin from seismic data and onshore-offshore correlation. Marine and Petroleum Geology 77: 1355-1375.

Aschoff JL, Steel RJ. 2011. Anatomy and development of a lowaccommodation clastic wedge, Upper Cretaceous, Cordilleran foreland basin, USA. Sedimentary Geology 236(1): 1-24.

Augier R, Agard P, Monié P, Jolivet L, Robin C, Booth-Rea G. 2005. Exhumation, doming and slab retreat in the Betic Cordillera (SE Spain): in situ 40Ar/39Ar ages and P-T-d-t paths for the NevadoFilabride complex. Journal of Metamorphic Geology 23(5): 357381.

Auzende JM, Olivet JL, Bonnin J. 1974. Le détroit sardano-tunisien et la zone de fracture nord-tunisienne. Tectonophysics 21(4): 357374.

Beaumont C, Fullsack P, Hamilton J. 1992. Erosional control of active compressional orogens. Thrust Tectonics 99: 1-18.
Belayouni H, Guerrera F, Martín-Martín M, Serrano F. 2013. Paleogeographic and geodynamic Miocene evolution of the Tunisian Tell (Numidian and Post-Numidian successions): bearing with the Maghrebian chain. International Journal of Earth Sciences 102(3): 831-855.

Beltrando M, Compagnoni R, Lombardo B. 2010. (Ultra-) Highpressure metamorphism and orogenesis: an Alpine perspective. Gondwana Research 18(1): 147-166.

Benzaggagh M. 2011. Activités volcaniques sous-marines à la limite Jurassique-Crétacé dans le Rif externe (Maroc). Âge et relation avec la sédimentation et la paléogéographie du sillon rifain externe. Comptes Rendus Geoscience 343(4): 302-311.

Benzaggagh M, Mokhtari A, Rossi P, Michard A, El Maz A, Chalouan A, et al. 2014. Oceanic units in the core of the External Rif (Morocco): intramargin hiatus or South-Tethyan remnants? Journal of Geodynamics 77: 4-21.

Bergerat F. 1985. Déformations cassantes et champs de contrainte tertiaires dans la plate-forme européenne. Paris, France: Université Pierre et Marie Curie-Paris VI.

Bertotti G, Picotti V, Bernoulli D, Castellarin A. 1993. From rifting to drifting: tectonic evolution of the South-Alpine upper crust from the Triassic to the Early Cretaceous. Sedimentary Geology 86(1-2): 53-76.

Biari Y, Klingelhoefer F, Sahabi M, Funck T, Benabdellouahed M, Schnabel M, et al. 2017. Opening of the central Atlantic Ocean: implications for geometric rifting and asymmetric initial seafloor spreading after continental breakup. Tectonics 36(6): 1129-1150.

Bles J-L. 1971. Étude tectonique et microtectonique d'un massif autochtone tellien et de sa couverture de nappes ; le Massif de Blida (Algerie du Nord). Bulletin de la Société Géologique de France 7 (5-6): 498-511.

Bonnet C, Malavieille J, Mosar J. 2007. Interactions between tectonics, erosion, and sedimentation during the recent evolution of the Alpine orogen: analogue modeling insights. Tectonics 26(6).

Booth-Rea G, Ranero CR, Martinez-Martinez JM, Grevemeyer I. 2007. Crustal types and Tertiary tectonic evolution of the Alborán sea, western Mediterranean. Geochemistry, Geophysics, Geosystems $8(10)$.

Booth-Rea G, Jabaloy-Sánchez A, Azdimousa A, Asebriy L, Vílchez MV, Martínez-Martínez JM. 2012. Upper-crustal extension during oblique collision: the Temsamane extensional detachment (eastern Rif, Morocco). Terra Nova 24(6): 505-512.

Bouillin J-P. 1979. La transversale de Collo et d'El Milia (Petite Kabylie): une région-clef pour l'interprétation de la tectonique alpine de la chaîne littorale d'Algérie. Société géologique de France.

Bouillin J-P. 1986. Le «bassin maghrebin »; une ancienne limite entre l'Europe et l'Afrique à 1'ouest des Alpes. Bulletin de La Société Géologique de France 2(4): 547-558.

Bouillin J, Durand-Delga M, Gelard JP, Leikine M, Raoult JF, Raymond D, et al. 1970. Définition d'un flysch massylien et d'un flysch maurétanien au sein des flyschs allochtones de l'Algérie. $C R$ Acad. Sci. Paris 270: 2249-2252.

Bouillin J-P, Kornprobst J, Raoult JF. 1977. Donnees preliminaires sur le complexe volcanosedimentaire de Rekkada Metletine (exTexenna), en Petite Kabylie (Algerie). Bulletin de La Société Géologique de France 7(4): 805-813.

Bouillin J-P, Perret MF. 1982. Datation par conodontes du Carbonifère inférieur et mise en évidence d'une phase tectonique bretonne en Petite Kabylie (Algérie). CR Acad. Sci. Paris, Ser. II 295: 47-50.

Bouillin J-P, Monié P, Rolfo F, Tricart P, Mascle G, Torelli L, et al. 1999. Données géochronologiques $40 \mathrm{Ar} / 39 \mathrm{Ar}$ sur les socles sarde et kabylo-péloritain submergés dans le canal de Sardaigne 
(Méditerranée occidentale). Comptes Rendus de l'Académie Des Sciences-Series IIA-Earth and Planetary Science 328(8): 529-534.

Bousquet R, Oberhänsli R, Goffé B, Wiederkehr M, Koller F, Schmid SM, et al. 2008. Metamorphism of metasediments at the scale of an orogen: a key to the Tertiary geodynamic evolution of the Alps. Geological Society, London, Special Publications 298 (1): 393-411.

Bouyahiaoui B, Sage F, Abtout A, Klingelhoefer F, Yelles-Chaouche A, Schnürle P, et al. 2015. Crustal structure of the eastern Algerian continental margin and adjacent deep basin: implications for late Cenozoic geodynamic evolution of the western Mediterranean. Geophysical Journal International 201(3): 1912-1938.

Bracène R, Frizon de Lamotte D. 2002. The origin of intraplate deformation in the Atlas system of western and central Algeria: from Jurassic rifting to Cenozoic-Quaternary inversion. Tectonophysics 357(1): 207-226.

Bruguier O, Hammor D, Bosch D, Caby R. 2009. Miocene incorporation of peridotite into the Hercynian basement of the Maghrebides (Edough massif, NE Algeria): implications for the geodynamic evolution of the Western Mediterranean. Chemical Geology 261(1): 172-184.

Bruguier O, Bosch D, Caby R, Vitale-Brovarone A, Fernandez L, Hammor D, et al. 2017. Age of UHP metamorphism in the Western Mediterranean: insight from rutile and minute zircon inclusions in a diamond-bearing garnet megacryst (Edough Massif, NE Algeria). Earth and Planetary Science Letters 474: 215-225.

Bulundwe Kitongo MK. 1987. Stratigraphie des «sofs» jurassiques du Prérif interne, Maroc : Publications du Département de Géologie et de Paléontologie, Université de Genève, 4, 326 p.

Caby R, Hammor D. 1992. Le massif cristallin de l'Edough (Algérie) : un Métamorphic Core Complex d'âge miocčne dans les Maghrébides. Comptes Rendus de l'Académie Des Sciences. Série 2, Mécanique, Physique, Chimie, Sciences de L'univers, Sciences de La Terre 314(8): 829-835.

Caby R, Hammor D, Delor C. 2001. Metamorphic evolution, partial melting and Miocene exhumation of lower crust in the Edough metamorphic core complex, west Mediterranean orogen, eastern Algeria. Tectonophysics 342(3): 239-273.

Caby R, Bruguier O, Fernandez L, Hammor D, Bosch D, Mechati M, et al. 2014. Metamorphic diamonds in a garnet megacryst from the Edough Massif (northeastern Algeria). Recognition and geodynamic consequences. Tectonophysics 637: 341-353.

Cadet J-P, Funiciello R, Barrier E. 2004. Geodynamic map of the Mediterranean, CGMW, Paris. Paris, France: Commission de la Carte Géologique du Monde.

Caire A. 1957. Étude géologique de la région des Biban (Algérie). Publ. Serv. Carte Géol. Algérie, Nouv. Ser., Bull 16.

Capella W, Matenco L, Dmitrieva E, Roest WMJ, Hessels S, Hssain M, et al. 2017. Thick-skinned tectonics closing the Rifian Corridor. Tectonophysics. DOI: 10.1016/j.tecto.2016.09.028.

Carminati E, Lustrino M, Doglioni C. 2012. Geodynamic evolution of the central and western Mediterranean: Tectonics vs. igneous petrology constraints. Tectonophysics 579: 173-192.

Casas Sainz AM, Faccenna C. 2001. Tertiary compressional deformation of the Iberian plate. Terra Nova 13(4): 281-288.

Casciello E, Fernàndez M, Vergés J, Cesarano M, Torne M. 2015. The Alboran Domain in the Western Mediterranean evolution: the birth of a concept. Bulletin de La Société Géologique de France 186(4-5): 371384.

Casero P. 2004. Structural setting of petroleum exploration plays in Italy. Special Volume of the Italian Geological Society for the IGC 32: 189-199.
Casero P, Roure F, Vially R. 1991. Tectonic framework and petroleum potential of the southern Apennines. Generation, Accumulation, and Production of Europe's Hydrocarbons 1: 381-387.

Casero P, Roure F. 1994. Neogene deformations at the Sicilian-North African plate boundary. In: Peri-Tethyan: proceedings of the IFP/PERI-TETHYS Research conference held in Arles, France, March 23-25, 1993. Paris, Technip, France, pp. 27-50.

Catalano R. 1987. Northeastern Sicily straits. Stratigraphy and structures from seismic reflection profiles. Rend. Soc. Geol. It 9(2): 103-112.

Catalano R, D'argenio B, Montanari L, Morlotti E, Torelli L. 1985. Marine geology of the NW Sicily offshore (Sardinia Channel) and its relationships with mainland structures. Bollettino Della Societa Geologica Italiana 104(2): 207-215.

Catuneanu O. 2004. Basement control on flexural profiles and the distribution of foreland facies: the Dwyka Group of the Karoo Basin, South Africa. Geology 32(6): 517-520.

Chalouan A, Michard A. 1990. The Ghomarides nappes, Rif coastal range, Morocco: a variscan chip in the Alpine belt. Tectonics 9(6): 1565-1583.

Chamot-Rooke N, Gaulier J-M, Jestin F. 1999. Constraints on Moho depth and crustal thickness in the Liguro-Provençal basin from a 3D gravity inversion: geodynamic implications. Geological Society, London, Special Publications 156(1): 37-61.

Chazot G, Abbassene F, Maury RC, Déverchère J, Bellon H, Ouabadi A, et al. 2017. An overview on the origin of post-collisional Miocene magmatism in the Kabylies (northern Algeria): evidence for crustal stacking, delamination and slab detachment. Journal of African Earth Sciences 125: 27-41.

Cifelli F, Mattei M, Porreca M. 2008. New paleomagnetic data from Oligocene-upper Miocene sediments in the Rif chain (northern Morocco): insights on the Neogene tectonic evolution of the Gibraltar arc. Journal of Geophysical Research: Solid Earth 113 (B2).

Cifelli F, Caricchi C, Mattei M. 2016. Formation of arc-shaped orogenic belts in the Western and Central Mediterranean: a palaeomagnetic review. Geological Society, London, Special Publications 425(1): 37-63.

Ciszak R. 1993. Évolution géodynamique de la chaîne tellienne en Oranie (Algérie occidentale) pendant le Paléozoïque et le Mésozoïque. Toulouse, France: Univ. Toulouse 3.

Clark SR, Stegman D, Müller RD. 2008. Episodicity in back-arc tectonic regimes. Physics of the Earth and Planetary Interiors 171 (1): 265-279.

Comas MC, Platt JP, Soto JI, Watts AB. 1999. 44. The origin and tectonic history of the Alboran Basin: insights from Leg 161 results. In: Proceedings of the Ocean Drilling Program Scientific Results, Vol. 161, pp. 555-580.

Compagnoni R, Morlotti E, Torelli L. 1989. Crystalline and sedimentary rocks from the scarps of the Sicily-Sardinia Trough and Cornaglia Terrace (southwestern Tyrrhenian Sea, Italy): paleogeographic and geodynamic implications. Chemical Geology 77(3-4): 375-398.

Courme-Rault MD. 1984. Le Miocène de l'Algérie centrale et orientale: l'âge de la mise en place des nappes telliennes. Rev. Géogr. Phys. Géol. Dyn 25(2): 127-144.

Crespo-Blanc A, Orozco M, Garcia-Duenas V. 1994. Extensional versus compression during the Miocene tectonic evolution of the Betic chain. Late folding of normal fault system. Tectonic 13: $78-88$.

Crespo-Blanc A, Comas M, Balanyá JC. 2016. Clues for a Tortonian reconstruction of the Gibraltar Arc: structural pattern, deformation diachronism and block rotations. Tectonophysics 683: 308-324. 
D’Acremont E, Leroy S, Beslier M-O, Bellahsen N, Fournier M, Robin C, et al. 2005. Structure and evolution of the eastern Gulf of Aden conjugate margins from seismic reflection data. Geophysical Journal International 160(3): 869-890. DOI: 10.1111/ j.1365-246X.2005.02524.x.

Delteil J. 1974. Tectonique de la chaîne alpine en Algérie d'après l'étude du Tell Oranais oriental, Monts de la Mina, Beni Chougrane, Dahra. Nice, France: Univ. Nice.

Dercourt J, Gaetani M, Vrielynck B. 2000. Atlas Peri-Tethys, Palaeogeographical Maps-Explanatory Notes. Paris, France: Commission de la Carte Géologique du Monde.

Derder MEM, Henry B, Amenna M, Bayou B, Maouche S, Besse J, et al. 2011. Tectonic evolution of the active "Chelif" basin (Northern Algeria) from paleomagnetic and magnetic fabric investigations. In New Frontiers in Tectonic Research-At the Midst of Plate Convergence. InTech.

Derder MEM, Henry B, Maouche S, Bayou B, Amenna M, Besse J, et al. 2013. Transpressive tectonics along a major E-W crustal structure on the Algerian continental margin: blocks rotations revealed by a paleomagnetic analysis. Tectonophysics 593: 183192.

Déverchère J, Yelles K, Domzig A, Mercier de Lépinay B, Bouillin J, Gaullier V, et al. 2005. Active thrust faulting offshore Boumerdes, Algeria, and its relations to the $2003 \mathrm{Mw} 6.9$ earthquake. Geophysical Research Letters 32(4).

Di Paolo L, Olivetti V, Corrado S, Aldega L, Balestrieri ML, Maniscalco R. 2014. Detecting the stepwise propagation of the Eastern Sicily thrust belt (Italy): insight from thermal and thermochronological constraints. Terra Nova 26(5): 363-371.

Do Couto D, Gumiaux C, Augier R, Lebret N, Folcher N, Jouannic G, et al. 2014. Tectonic inversion of an asymmetric graben: Insights frm a combined field and gravity survey in the Sorbas Basin. Tectonics 33(7): 1360-1385.

Do Couto D, Gorini C, Jolivet L, Lebret N, Augier R, Gumiaux C, et al. 2016. Tectonic and stratigraphic evolution of the Western Alboran Sea Basin in the last 25 Myrs. Tectonophysics 677: 280311.

Doglioni C, Gueguen E, Sàbat F, Fernandez M. 1997. The western Mediterranean extensional basins and the Alpine orogen. Terra Nova 9(3): 109-112.

Doglioni C, Gueguen E, Harabaglia P, Mongelli F. 1999. On the origin of west-directed subduction zones and applications to the western Mediterranean. Geological Society, London, Special Publications 156(1): 541-561.

Domzig A. 2006. Déformation active et récente, et structuration tectono-sédimentaire de la marge sous-marine algérienne. Brest, France: Université de Brest.

Domzig A, Yelles A, Le Roy C, Déverchère J, Bouillin J-P., Bracène $\mathrm{R}$, et al. 2006. Searching for the Africa-Eurasia Miocene boundary offshore western Algeria (MARADJA'03 cruise). Comptes Rendus Geoscience 338(1): 80-91.

Durand-Delga M, Fontboté JM. 1980. Le cadre structural de la Méditerranée occidentale. In 26o Congrès Géol. Intern. Paris, Colloque no. 5, Les chaines alpines issues de la Téthis.

Durand-Delga M, Gardin S, Olivier P. 1999. Datation des flyschs éocrétacés maurétaniens des Maghrébides: la formation du Jbel Tisirène (Rif, Maroc). Comptes Rendus de l'Académie Des SciencesSeries IIA-Earth and Planetary Science 328(10): 701-709.

Durand-Delga M, Rossi P, Olivier P, Puglisi D. 2000. Situation structurale et nature ophiolitique de roches basiques jurassiques associées aux flyschs maghrébins du Rif (Maroc) et de Sicile (Italie). Comptes Rendus de l'Académie Des Sciences-Series IIAEarth and Planetary Science 331(1): 29-38.
Durand Delga M. 1969. Mise au point sur la structure du Nord-Est de la Berbérie. Publ. Serv. Carte géol. Algérie, NS. Bull. Soc. Géol. fr. Xiii(7): 328-337.

Durand Delga M, Hottinger L, Marcais J, Mattauer M, Milliard Y, Suter G. 1962. Données actuelles sur la structure du Rif. Livre À La Mémoire Du Professeur P. Fallot. Soc. Géol. Fr. Éd, T. I: 399.

Duretz T, Agard P, Yamato P, Ducassou C, Burov EB, Gerya TV. 2016. Thermo-mechanical modeling of the obduction process based on the Oman ophiolite case. Gondwana Research 32: 1-10.

Dobretsov NL, Vernikovsky VA, Karyakin Yu V, Korago EA, Simonov VA. 2013. Mesozoic-Cenozoic volcanism and geodynamic events in the Central and Eastern Arctic. Russian Geology and Geophysics 54: 874-887.

El Azzab D, Galdeano A, Feinberg H, Michard A. 1997. Prolongement en profondeur d'une ecaille ultrabasique allochtone; traitement des donnees aeromagnetiques et modelisation 3D des peridotites des Beni-Malek (Rif, Maroc). Bulletin de La Societe Geologique de France 168(1): 15 LP-23. Retrieved from http:// bsgf.geoscienceworld.org/content/168/1/15.abstract.

Etheve N, de Lamotte DF, Mohn G, Martos R, Roca E, Blanpied C. 2016. Extensional vs. contractional Cenozoic deformation in Ibiza (Balearic Promontory, Spain): integration in the West Mediterranean back-arc setting. Tectonophysics 682: 35-55.

Faccenna C, Becker TW, Lucente FP, Jolivet L, Rossetti F. 2001. History of subduction and back arc extension in the Central Mediterranean. Geophysical Journal International 145(3): 809820.

Faccenna C, Piromallo C, Crespo-Blanc A, Jolivet L, Rossetti F. 2004. Lateral slab deformation and the origin of the western Mediterranean arcs. Tectonics 23(1).

Faccenna C, Becker TW, Auer L, Billi A, Boschi L, Brun JP, et al. 2014. Mantle dynamics in the Mediterranean. Reviews of Geophysics 52(3): 283-332.

Faugères J-C. 1978. Les rides sud-rifaines : évolution sédimentaire et structurale d'un bassin atlantico-mésogéen de la marge africaine. Bordeaux, France: Univ. Bordeaux.

Favre P. 1992. Géologie des massifs calcaires situés au front sud de l'unité de Ketama (Rif, Maroc). Section des sciences de la terre.

Favre P. 1995. Analyse quantitative du rifting et de la relaxation thermique de la partie occidentale de la marge transformante nordafricaine : le Rif externe (Maroc) Comparaison avec la structure actuelle de la chaïne. Geodinamica Acta 8(2): 59-81.

Favre P, Stampfli G, Wildi W. 1991. Jurassic sedimentary record and tectonic evolution of the northwestern corner of Africa. Palaeogeography, Palaeoclimatology, Palaeoecology 87(1-4): 53-73.

Fedan B. 1988. Évolution géodynamique d'un bassin intraplaque sur decrochements: le Moyen Atlas (Maroc) durant le MésoCénozoïque. Rabat, Morocco: Faculté Sci. Rabat, Univ. Moh. V.

Feinberg H. 1986. Les séries tertiaires des zones externes du Rif (Maroc) : biostratigraphie, paléogéographie et aperçu tectonique. Rabat, Morocco: Éditions du Service géologique du Maroc.

Fenet B. 1975. Recherches sur l'alpinisation de la bordure septentrionale du bouclier africain: à partir de l'étude d'un élément de l'Orogène nord-maghrébin: les Monts du Djebel Tessala et les Massifs du littoral oranais. Nice, France: Univ. Nice.

Fenet B, Macoin P, Magne J. 1969. Mise en evidence d'une phase tectonique intra-lutetienne dans l'unité de Sidi el Hadri (monts du Tessala, Algerie occidentale). Bulletin de La Société Géologique de France 7(6): 904-908.

Fernandez L, Bosch D, Bruguier O, Hammor D, Caby R, Monié P, et al. 2016. Permo-carboniferous and early miocene geological evolution of the internal zones of the Maghrebides-new insights on 
the western Mediterranean evolution. Journal of Geodynamics 96: 146-173.

Fillon C, van der Beek P. 2012. Post-orogenic evolution of the southern Pyrenees: constraints from inverse thermo-kinematic modelling of low-temperature thermochronology data. Basin Research 24(4): 418-436.

Fillon C, Huismans RS, van der Beek P. 2013. Syntectonic sedimentation effects on the growth of fold-and-thrust belts. Geology 41(1): 83-86.

Flecker R, Krijgsman W, Capella W, de Castro Martíns C, Dmitrieva E, Mayser JP, et al. 2015. Evolution of the Late Miocene Mediterranean-Atlantic gateways and their impact on regional and global environmental change. Earth-Science Reviews 150: 365-392.

Flinch JF. 1994. Tectonic evolution of the Gibraltar Arc. Houston, Texas, US: Rice University.

Frizon de Lamotte D. 1985. La structure du Rif Oriental (Maroc) : rôle de la tectonique longitudinale et importance des fluides.

Frizon de Lamotte D. 1987. Un exemple de collage synmetamorphe. La deformation miocene des Temsamane (Rif externe, Maroc). Bulletin de la Société Géologique de France 3(2): 337-344.

Frizon de Lamotte D, Andrieux J, Guézou J-C. 1991. Cinematique des chevauchements neogenes dans l'Arc betico-rifain; discussion sur les modeles geodynamiques. Bulletin de la Société Géologique de France, 162(4): 611-626.

Frizon de Lamotte D, Leikine M. 1985. Métamorphisme miocène du Rif oriental (Maroc) et individualisation de la nappe gravitaire d'Aknoul. Revue de Géologie Dynamique et de Géographie Physique 26(1): 29-42.

Frizon de Lamotte D, Saint Bezar B, Bracène R, Mercier E. 2000. The two main steps of the Atlas building and geodynamics of the western Mediterranean. Tectonics 19(4): 740-761. DOI: 10.1029/ 2000 TC900003.

Frizon de Lamotte D, Leturmy P, Missenard Y, Khomsi S, Ruiz G, Saddiqi O, et al. 2009. Mesozoic and Cenozoic vertical movements in the Atlas system (Algeria, Morocco, Tunisia): an overview. Tectonophysics 475(1): 9-28.

Frizon de Lamotte D, Raulin C, Mouchot N, Wrobel-Daveau J, Blanpied C, Ringenbach J. 2011. The southernmost margin of the Tethys realm during the Mesozoic and Cenozoic: initial geometry and timing of the inversion processes. Tectonics 30(3).

Gaina C, Roest WR, Müller RD. 2002. Late Cretaceous-Cenozoic deformation of northeast Asia. Earth and Planetary Science Letters 197(3): 273-286.

García-Hernández M, López-Garrido AC, Martín-Algarra A, Molina JM, Ruiz-Ortiz PA, Vera JA. 1989. Las discontinuidades mayores del Jurásico de las Zonas Externas de las Cordilleras Béticas: análisis e interpretación de los ciclos sedimentarios. Cuadernos de Geología Ibérica 13: 35-52.

Gélard J-P. 1979. Géologie du nord-est de la grande Kabylie: un segment des zones internes de l'orogene littoral maghrebin, Vol. 5. Dijon, France: Institut des sciences de la terre.

Géry B, Feinberg H, Lorenz C, Magné J. 1981. Définition d'une série type de «l'Oligo-miocene Kabyle» anté-nappes dans le Djebel Aissa-Mimoun (grande Kabylie, Algérie). CR Acad. Sci. Paris 292: 1529-1532.

Ghandriche H. 1991. Modalités de la superposition de structures de plissement-chevauchement d'âge alpin dans les Aurès (Algérie). Orsay, France: Univ. Paris XI Sud.

Girardeau J, Cornen G, Beslier MO, Le Gall B, Monnier C, Agrinier $\mathrm{P}$, et al. 1998. Extensional tectonics in the Gorringe Bank rocks, Eastern Atlantic Ocean: evidence of an oceanic ultra-slow mantellic accreting centre. Terra Nova 10: 330-336.
Goffé B, Michard A, Kienast JR, Le Mer O. 1988. A case of obduction-related high-pressure, low-temperature metamorphism in upper crustal nappes, Arabian continental margin, Oman: PT paths and kinematic interpretation. Tectonophysics 151(1-4): 363-386.

Guardia P. 1975. Géodynamique de la marge alpine du continent africain d'après l'étude de l'Oranie nord-occidentale: relations structurales et paléogéographiques entre le Rif externe, le Tell et l'avant-pays atlasique. Nice, France: Univ. Nice.

Guardia P. 1990. Carte géologique de Bensekrane au 1/50 000. Inst Nat Carto Alger: 239.

Guardia P, Fenet B. 1987. Carte géologique de Sidi Ali Boussidi au 1/ 50 000. Inst Nat Carto Alger: 240.

Gueguen E, Doglioni C, Fernandez M. 1998. On the post-25 Ma geodynamic evolution of the western Mediterranean. Tectonophysics 298(1): 259-269.

Guerrera F, Martín-Martín M. 2014. Geodynamic events reconstructed in the Betic, Maghrebian, and Apennine chains (centralwestern Tethys). Bulletin de La Société Géologique de France 185 (5): 329-341.

Guerrera F, Martín-Algarra A, Perrone V. 1993. Late OligoceneMiocene syn-/-late-orogenic successions in Western and Central Mediterranean Chains from the Betic Cordillera to the Southern Apennines. Terra Nova 5(6): 525-544.

Guerrera F, Martín-Martín M, Perrone V, Tramontana M. 2005. Tectono-sedimentary evolution of the southern branch of the Western Tethys (Maghrebian Flysch Basin and Lucanian Ocean): consequences for Western Mediterranean geodynamics. Terra Nova 17(4): 358-367.

Guerrera F, Martín-Algarra A, Martín-Martín M. 2012. Tectonosedimentary evolution of the "Numidian Formation" and Lateral Facies (southern branch of the western Tethys): constraints for central-western Mediterranean geodynamics. Terra Nova 24(1): 34-41.

Guimerá J, Mas R, Alonso Á. 2004. Intraplate deformation in the NW Iberian Chain: Mesozoic extension and Tertiary contractional inversion. Journal of the Geological Society 161(2): 291-303.

Guiraud R, Bellion Y, Benkhelil J, Moreau C. 1987. Post-Hercynian tectonics in Northern and Western Africa. Geological Journal 22 (S2): 433-466.

Guiraud R, Bosworth W, Thierry J, Delplanque A. 2005. Phanerozoic geological evolution of Northern and Central Africa: an overview. Journal of African Earth Sciences 43(1): 83-143.

Hall CE, Gurnis M, Sdrolias M, Lavier LL, Müller RD. 2003. Catastrophic initiation of subduction following forced convergence across fracture zones. Earth and Planetary Science Letters 212: 15-30.

Han L, Hole JA, Stock JM, Fuis GS, Kell A, Driscoll NW, et al. 2016. Continental rupture and the creation of new crust in the Salton Trough rift, Southern California and northern Mexico: results from the Salton Seismic Imaging Project. Journal of Geophysical Research: Solid Earth 121(10): 7469-7489. DOI: 10.1002/ 2016JB013139.

Handy MR, Schmid SM, Bousquet R, Kissling E, Bernoulli D. 2010. Reconciling plate-tectonic reconstructions of Alpine Tethys with the geological-geophysical record of spreading and subduction in the Alps. Earth-Science Reviews 102(3): 121-158.

Hassani MI. 1987. Hydrogéologie d'un bassin endoréique semiaride: le bassin versant de la grande Sebkha d'Oran (Algérie). Grenoble, France: Université Scientifique et Médicale de Grenoble.

Hervouët Y. 1985. Évolution tectonique de l'avant pays rifain oriental (orogène alpine, Maroc). Rev. Géol. Dyn. \& Géogr. Phys 27(1): 25-35. 
Hervouët Y, De Luca P. 1980. Place de l'unité chaotique de GarebKebdana dans l'orogene rifain; implications geodynamiques. Bulletin de La Société Géologique de France 7(3): 305-310.

Heuret A, Lallemand S. 2005. Plate motions, slab dynamics and backarc deformation. Physics of the Earth and Planetary Interiors 149 (1): 31-51.

Heuret A, Funiciello F, Faccenna C, Lallemand S. 2007. Plate kinematics, slab shape and back-arc stress: a comparison between laboratory models and current subduction zones. Earth and Planetary Science Letters 256(3): 473-483.

Heymes T, Bouillin J, Pecher A, Monié P, Compagnoni R. 2008. Middle Oligocene extension in the Mediterranean CalabroPeloritan belt (southern Italy): insights from the Aspromonte nappes pile. Tectonics 27(2).

Heymes T, Monié P, Arnaud N, Pêcher A, Bouillin J-P, Compagnoni R. 2010. Alpine tectonics in the Calabrian-Peloritan belt (southern Italy): new $40 \mathrm{Ar} / 39 \mathrm{Ar}$ data in the Aspromonte Massif area. Lithos 114(3): 451-472.

Hilly J. 1962. Étude géologique du Massif de l'Edough et du Cap de Fer:(Est-Constantinois). Service de la carte géologique de l'Algérie.

Hottinger L, Suter G. 1962. Géologie-La structure de la zone prérifaine au sud du Moyen Ouerrha (Maroc septentrional). Comptes Rendus Hebdomadaires Des Séances de l'Académie Des Sciences 254(1): 140.

Jabaloy A, Galindo-Zaldivar J, Gonzalez-Lodeiro F. 1993. The Alpujarride-Nevado-Filabride extensional shear zone, Betic Cordillera, SE Spain. Journal of Structural Geology 15: 555-569.

Jabaloy-Sánchez A, Azdimousa A, Booth-Rea G, Asebriy L, Vázquez-Vílchez M, Martínez-Martínez JM, et al. 2015. The structure of the Temsamane fold-and-thrust stack (eastern Rif, Morocco): evolution of a transpressional orogenic wedge. Tectonophysics 663: 150-176.

Janowski M, Loget N, Gautheron C, Barbarand J, Bellhasen N, van den Driessche J, et al. 2017. Neogene exhumation and relief evolution in the eastern Betics (SE Spain): insights from the Sierra de Gador. Terra Nova: 29(2): 91-97.

Jiménez-Munt I, Fernàndez M, Vergés J, Afonso JC, GarciaCastellanos D, Fullea J. 2010. Lithospheric structure of the Gorringe Bank: insights into its origin and tectonic evolution. Tectonics 29(5).

Jolivet L, Faccenna C. 2000. Mediterranean extension and the AfricaEurasia collision. Tectonics 19(6): 1095-1106.

Jolivet L, Augier R, Faccenna C, Negro F, Rimmele G, Agard P, et al. 2008. Subduction, convergence and the mode of backarc extension in the Mediterranean region. Bulletin de la Société Géologique de France 179(6): 525-550.

Jolivet L, Faccenna C, Agard P, Frizon de Lamotte D, Menant A, Sternai $\mathrm{P}$, et al. 2016. Neo-Tethys geodynamics and mantle convection: from extension to compression in Africa and a conceptual model for obduction. Canadian Journal of Earth Sciences 53(11): 1190-1204. DOI: 10.1139/cjes-2015-0118.

Kherroubi A, Déverchère J, Yelles A, De Lépinay BM, Domzig A, Cattaneo A, et al. 2009. Recent and active deformation pattern off the easternmost Algerian margin, Western Mediterranean Sea: new evidence for contractional tectonic reactivation. Marine Geology 261(1): 17-32.

Khomsi S, Bédir M, Zouari H, Jemia MG Ben. 2004. Mise en évidence et analyse d'une structure atlasique ennoyée au front de la Chaîne alpine tunisienne. Comptes Rendus Geoscience 336(14): 1293-1300.

Khomsi S, de Lamotte DF, Bédir M, Echihi O. 2016. The Late Eocene and Late Miocene fronts of the Atlas Belt in eastern Maghreb: integration in the geodynamic evolution of the Mediterranean Domain. Arabian Journal of Geosciences 9(15): 650.

Kieken M. 1975. Étude géologique du Hodna, du Titteri et de la partie occidentale des Biban. Algérie. Publ. Serv. Géol. Algérie 46: 486.

Kireche O. 1977. Étude géologique et structurale des massifs de la plaine du Chéliff (Doui, Rouina, Tamoulga). Doctorat $3^{\mathrm{e}}$ Cycle. Algeria: University of Algiers.

Kley V, Voigt T. 2008. Late Cretaceous intraplate thrusting in central Europe: Effect of Africa-Iberia-Europe convergence, not Alpine collision. Geology 36(11): 839-842.

Klingelhoefer F, Biari Y, Sahabi M, Aslanian D, Schnabel M, Matias L, et al. 2016. Crustal structure variations along the NW-African continental margin: a comparison of new and existing models from wide-angle and reflection seismic data. Tectonophysics 674: 227-252.

Kornprobst J, Delteil J. 1976. Existence d'un affleurement de webstérite à spinelle d'origine mantellique dans le Trias d'une unité du Tell méridional au voisinage de Mendès (Wilaya de TiaretAlgérie). Comptes Rendus de l'Académie Des Sciences Paris 283: 1699-1701.

Labails C. 2007. La marge sud-marocaine et les premières phases d'ouverture de l'océan Atlantique Central. Brest, France: Université de Bretagne Occidentale.

Labails C, Olivet J-L., Aslanian D, Roest WR. 2010. An alternative early opening scenario for the Central Atlantic Ocean. Earth and Planetary Science Letters 297(3): 355-368.

Lacombe O, Jolivet L. 2005. Structural and kinematic relationships between Corsica and the Pyrenees-Provence domain at the time of the Pyrenean orogeny. Tectonics 24(1).

Laffitte R. 1939. Étude géologique de l'Aurès [Algérie]. Service de la carte géologique de l'Algérie.

Lafosse M, d'Acremont E, Rabaute A, Mercier de Lépinay B, Tahayt A, Ammar A, et al. 2017. Evidence of Quaternary transtensional tectonics in the Nekor basin (NE Morocco). Basin Research 29(4): $470-489$.

Lallemand S, Heuret A, Boutelier D. 2005. On the relationships between slab dip, back-arc stress, upper plate absolute motion, and crustal nature in subduction zones. Geochemistry, Geophysics, Geosystems 6(9).

Leblanc D. 1979. Étude géologique du Rif externe oriental au Nord de Taza (Maroc). Rabat, Morocco: Éditions du Service géologique du Maroc.

Leblanc D, Feinberg H. 1982. Nouvelles donnees stratigraphiques et structurales sur le Numidien du Rif oriental (Maroc); implications geodynamiques. Bulletin de La Société Géologique de France 7(4): 861-865.

Leikine M. 1971. Étude géologique des Babors occidentaux. Thèse de Doctorat. Sciences. Université Paris, $530 \mathrm{p}$.

Leleu S, Hartley AJ, van Oosterhout C, Kennan L, Ruckwied K, Gerdes K. 2016. Structural, stratigraphic and sedimentological characterisation of a wide rift system: the Triassic rift system of the Central Atlantic Domain. Earth-Science Reviews 158: 89-124.

Leprêtre A, Klingelhoefer F, Graindorge D, Schnurle P, Beslier M-O., Yelles K, et al. 2013. Multiphased tectonic evolution of the Central Algerian margin from combined wide-angle and reflection seismic data off Tipaza, Algeria. Journal of Geophysical Research: Solid Earth 118(8): 3899-3916.

Leprêtre R, Missenard Y, Barbarand J, Gautheron C, Jouvie I, Saddiqi O. 2018. Polyphased inversions of an intracontinental rift: case study of the Marrakech High Atlas, Morocco. Tectonics 37(3): 818-841.

Lepvrier C. 1970. La zone kabyle et l'origine des flyschs dans la région du Chenoua et du Cap Ténès (Algérie). CR Somm. Soc. Géol. Fr: 248-251. 
Lepvrier C. 1971. Données relatives à la schistosité et au métamorphisme dans les massifs du Chélif et du Bou Maad (autochtone nord-et méso-tellien, Algérie). Comptes Rendus À l'Académie Des Sciences de Paris 273: 284-286.

Lepvrier C. 1978. Les plis couchés synschisteux des massifs du Chéliff (Tell algérois, Algérie): une tectonique d'âge Crétacé supérieur. Rev Geol Dyn Geogr 20(1): 123-136.

Li B, Massonne H-J. 2018. Two Tertiary metamorphic events recognized in high-pressure metapelites of the Nevado-Filábride Complex (Betic cordillera, S Spain). Journal of Metamorphic Geology 36(5): 603-630.

Lombardo B, Rubatto D, Castelli D. 2002. Ion microprobe U-Pb dating of zircon from a Monviso metaplagiogranite: implications for the evolution of the Piedmont-Liguria Tethys in the Western Alps. Ofioliti 27(2): 109-117.

Lonergan L, White N. 1997. Origin of the Betic-Rif mountain belt. Tectonics 16(3): 504-522.

López-Blanco M, Marzo M, Burbank DW, Vergés J, Roca E, Anadón $\mathrm{P}$, et al. 2000. Tectonic and climatic controls on the development of foreland fan deltas: Montserrat and Sant Llorenç del Munt systems (Middle Eocene, Ebro Basin, NE Spain). Sedimentary Geology 138 (1): 17-39.

Mahdjoub Y, Choukroune P, Kienast J-R. 1997. Kinematics of a complex Alpine segment; superimposed tectonic and metamorphic events in the Petite Kabylie Massif (northern Algeria). Bulletin de la Société Géologique de France 168(5): 649-661.

Malavieille J. 2010. Impact of erosion, sedimentation, and structural heritage on the structure and kinematics of orogenic wedges: Analog models and case studies. GSA Today 20(1): 4-10.

Malavieille J, Konstantinovskaya E. 2010. Impact of surface processes on the growth of orogenic wedges: insights from analog models and case studies. Geotectonics 44(6): 541-558.

Malinverno A, Ryan WBF. 1986. Extension in the Tyrrhenian Sea and shortening in the Apennines as result of arc migration driven by sinking of the lithosphere. Tectonics 5(2): 227-245.

Manatschal G, Müntener O. 2009. A type sequence across an ancient magma-poor ocean-continent transition: the example of the western Alpine Tethys ophiolites. Tectonophysics 473(1): 4-19.

Mancilla FL, Booth-Rea G, Stich D, Pérez-Peña JV, Morales J, Azañón JM, et al. 2015. Slab rupture and delamination under the Betics and Rif constrained from receiver functions. Tectonophysics 663: 225-237.

Marçais J. 1936. La constitution géologique de la région au Nord de Taza et de Guercif (Maroc oriental). CR Acad. Sci. Paris 202: 1165-1167.

Mary BCL, Maillot B, Leroy YM. 2013. Predicting orogenic wedge styles as a function of analogue erosion law and material softening. Geochemistry, Geophysics, Geosystems 14(10): 4523-4543.

Mascle GH, Tricart P, Torelli L, Bouillin JP, Compagnoni R, Depardon S, et al. 2004. Structure of the Sardinia Channel: crustal thinning and tardi-orogenic extension in the Apenninic-Maghrebian orogen; results of the Cyana submersible survey (SARCYA and SARTUCYA) in the western Mediterranean. Bulletin de La Société Géologique de France 175(6): 607-627.

Mattauer M. 1958. Étude géologique de l'Ouarsenis oriental. Publ. Serv. Carte Géol. Algérie, Nouv. Ser., Bull (17). Alger: Service de la carte géologique de l'Algérie.

Mauffret A, Frizon de Lamotte D, Lallemant S, Gorini C, Maillard A. 2004. E-W opening of the Algerian Basin (western Mediterranean). Terra Nova 16(5): 257-264.

Medaouri M, Déverchère J, Graindorge D, Bracene R, Badji R, Ouabadi A, et al. 2014. The transition from Alboran to Algerian basins (Western Mediterranean Sea): chronostratigraphy, deep crustal structure and tectonic evolution at the rear of a narrow slab rollback system. Journal of Geodynamics 77: 186-205.

Meghraoui M. 1982. Étude neotectonique de la region nord-est d'El Asnam: relation avec le séisme du 10.10. 1980.

Meghraoui M, Cisternas A, Philip H. 1986. Seismotectonics of the lower Cheliff basin: structural background of the El Asnam (Algeria) earthquake. Tectonics 5(6): 809-836.

Meghraoui M, Morel J-L, Andrieux J, Dahmani M. 1996. Tectonique plio-quaternaire de la chaîne tello-rifaine et de la mer d'Alboran. Une zone complexe de convergence continent-continent. Bull. Soc. Geol. Fr 167(1): 141-157.

Michard A, Feinberg H, El-Azzab D, Bouybaouene M, Saddiqi O. 1992. A serpentinite ridge in a collisional paleomargin setting: the Beni Malek massif, External Rif, Morocco. Earth and Planetary Science Letters 113(3): 435-442.

Michard A, Chalouan A, Feinberg H, Goffé B, Montigny R. 2002. How does the Alpine belt end between Spain and Morocco? Bulletin de La Société Géologique de France 173(1): 3-15.

Michard A, Negro F, Saddiqi O, Bouybaouene ML, Chalouan A, Montigny R, et al. 2006. Pressure-temperature-time constraints on the Maghrebide mountain building: evidence from the Rif-Betic transect (Morocco, Spain), Algerian correlations, and geodynamic implications. Comptes Rendus Geoscience 338(1): 92-114.

Michard A, Negro F, Frizon de Lamotte D, Saddiqi O. 2007. Serpentinite slivers and metamorphism in the External Maghrebides: arguments for an intracontinental suture in the African paleomargin (Morocco, Algeria). Rev. Soc. Geol. España 20(3-4): 173-185.

Michard A, Mokhtari A, Chalouan A, Saddiqi O, Rossi P, Rjimati EC. 2014. New ophiolite slivers in the External Rif belt, and tentative restoration of a dual Tethyan suture in the western Maghrebides. Bulletin de La Société Géologique de France 185(5): 313-328.

Midoun M. 1989. Étude du trias d'oranie (algerie) et de ses relations avec le socle polymetamorphique: implications geodynamiques regionales. Orleans, France: Univ. Orleans.

Midoun M, Seddiki A. 2016. The mafic, ultramafic and metamorphic xenoliths in Triassic evaporite complexes, North West Algeria. Boletin Geologico y Minero 127(2-3): 333-344.

Monié P, Frizon de Lamotte D, Leikine M. 1984. Étude géochronologique préliminaire par la méthode $\mathrm{Ar} / \mathrm{Ar}$ du métamorphisme alpin dans le Rif externe (Maroc). Précisions sur le calendrier tectonique tertiaire. Revue de Geographie Physique et de Geologie Dynamique 25(4): 307-317.

Monié P, Montigny R, Maluski H. 1992. Âge burdigalien de la tectonique ductile extensive dans le massif de l'Edough (Kabylies, Algerie); donnees radiometriques $39 \mathrm{Ar}-40 \mathrm{Ar}$. Bulletin de La Société Géologique de France 163(5): 571-584.

Monié P, Torres-Roldán RL, Garcia-Casco A. 1994. Cooling and exhumation of the Western Betic Cordilleras, ${ }^{40} \mathrm{Ar} /{ }^{39} \mathrm{Ar}$ thermchronological constraints on a collapsed terrane. Tectonophysics 238(1-4): 353-379.

Montel JM, Kornprobst J, Vielzeuf D. 2000. Preservation of old U$\mathrm{Th}-\mathrm{Pb}$ ages in shielded monazite: example from the Beni Bousera Hercynian kinzigites (Morocco). Journal of Metamorphic Geology 18(3): 335-342.

Morel J-L. 1987. Évolution récente de l'orogène rifain et de son avant-pays depuis la fin de la mise en place des nappes (Rif, Maroc). Paris 11.

Morel JL, Meghraoui M. 1996. Goringe-Alboran-Tell tectonic zone: a transpression system along the Africa-Eurasia plate boundary. Geology 24(8): 755-758.

Muratet B. 1991. Carte géologique de Aïn Bni Mathar au 1/100 000, NI-30-XVI-2, Notes Mem. Serv. Géol. Maroc, n 361. 
Negro F, Beyssac O, Goffé B, Saddiqi O, Bouybaouene ML. 2006. Thermal structure of the Alboran Domain in the Rif (northern Morocco) and the Western Betics (southern Spain). Constraints from Raman spectroscopy of carbonaceous material. Journal of Metamorphic Geology 24(4): 309-327.

Negro F, Agard P, Goffé B, Saddiqi O. 2007. Tectonic and metamorphic evolution of the Temsamane units, External Rif (northern Morocco): implications for the evolution of the Rif and the Betic-Rif arc. Journal of the Geological Society 164(4): 829-842.

Negro F, De Sigoyer J, Goffé B, Saddiqi O, Villa IM. 2008. Tectonic evolution of the Betic-Rif arc: new constraints from $40 \mathrm{Ar} / 39 \mathrm{Ar}$ dating on white micas in the Temsamane units (External Rif, northern Morocco). Lithos 106(1): 93-109.

Neurdin-Trescartes J. 1992. Le remplissage sédimentaire du bassin néogène du Chelif, modèle de référence de bassins intramontagneux.

Nirrengarten M, Manatschal G, Tugend J, Kusznir N, Sauter D. 2018. Kinematic evolution of the Southern North Atlantic: implications for the formation of hyperextended systems. Tectonics 37(1): 89-118.

Nocquet J-M, Calais E. 2004. Geodetic measurements of crustal deformation in the Western Mediterranean and Europe. In Geodynamics of Azores-Tunisia. Pure and Applied Geophysics 161(3): 661-681.

Obert D. 1981. Étude géologique des Babors orientaux (domaine tellien, Algérie).

Olsen PE. 1997. Stratigraphic record of the early Mesozoic breakup of Pangea in the Laurasia-Gondwana rift system. Annual Review of Earth and Planetary Sciences 25(1): 337-401.

Palomeras I, Thurner S, Levander A, Liu K, Villasenor A, Carbonell $\mathrm{R}$, et al. 2014. Finite-frequency Rayleigh wave tomography of the western Mediterranean: mapping its lithospheric structure. Geochemistry, Geophysics, Geosystems 15(1): 140-160.

Papillon R. 1989. Stratigraphie des sofs Lias-Dogger des massif des Senhadja et de l'Azrou Akchar, Maroc: Université de Genève.

Pérouse E, Vernant P, Chéry J, Reilinger R, McClusky S. 2010. Active surface deformation and sub-lithospheric processes in the western Mediterranean constrained by numerical models. Geology 38(9): 823-826.

Perrodon A. 1957. Étude géologique des bassins néogènes sublittoraux de l'Algérie occidentale. France: Faculté des Sciences, Univ. Nancy.

Peucat JJ, Bossière G. 1981. Ages Rb-Sr sur micas du socle métamorphique Kabyle (Algérie) : mise en évidence d'évènements thermiques alpins. Bulletin de La Société géologique de France 7 (5): 439-447.

Platt JP. 1986. Dynamics of orogenic wedges and the uplift of high-pressure metamorphic rocks. GSA Bulletin 97(9): 1037-1053.

Platt JP. 1988. The mechanics of frontal imbrication: a first-order analysis. Geologische Rundschau 77(2): 577-589.

Platt JP, Whitehouse MJ. 1999. Early Miocene high-temperature metamorphism and rapid exhumation in the Betic Cordillera (Spain): evidence from U-Pb zircon ages. Earth and Planetary Science Letters 171(4): 591-605.

Platt JP, Whitehouse MJ, Kelley SP, Carter A, Hollick L. 2003. Simultaneous extensional exhumation across the Alboran Basin: implications for the causes of late orogenic extension. Geology 31 (3): 251-254.

Platt JP, Kelley SP, Carter A, Orozco M. 2005. Timing of tectonic events in the Alpujárride Complex, Betic Cordillera, southern Spain. Journal of the Geological Society 162(3): 451-462.
Platt JP, Behr WM, Johanesen K, Williams JR. 2013. The Betic-Rif arc and its orogenic hinterland: a review. Annual Review of Earth and Planetary Sciences 41: 313-357.

Polvêche J. 1960. Contribution à l'étude géologique de l'Ouarsenis oranais. Université de Lille.

Puga E, Nieto JM, de Federico AD, Bodinier JL, Morten L. 1999. Petrology and metamorphic evolution of ultramafic rocks and dolerite dykes of the Betic Ophiolitic Association (Mulhacén Complex, SE Spain): evidence of eo-Alpine subduction following an ocean-floor metasomatic process. Lithos 49(1): 23-56.

Puga E, Fanning M, de Federico AD, Nieto JM, Beccaluva L, Bianchini G, et al. 2011. Petrology, geochemistry and U-Pb geochronology of the Betic Ophiolites: inferences for Pangaea break-up and birth of the westernmost Tethys Ocean. Lithos 124(3): 255-272.

Rabaute A, Chamot-Rooke N. 2014. Active tectonics of the AfricaEurasia boundary from Algiers to Calabria (1/500 000). DOI: 10.13140/RG.2.2.23493.86245.

Ramos A, Fernández O, Terrinha P, Muñoz JA. 2016. Extension and inversion structures in the Tethys-Atlantic linkage zone, Algarve Basin, Portugal. International Journal of Earth Sciences 105(5): 1663-1679.

Ramos A, Fernández O, Terrinha P, Muñoz JA. 2017a. Neogene to recent contraction and basin inversion along the Nubia-Iberia boundary in SW Iberia. Tectonics 36(2): 257-286. DOI: 10.1002/ 2016TC004262.

Ramos A, Fernández O, Torne M, de la Muela AS, Muñoz JA, Terrinha $\mathrm{P}$, et al. 2017b. Crustal structure of the SW Iberian passive margin: The westernmost remnant of the Ligurian Tethys? Tectonophysics 705: 42-62.

Rehault J-P., Boillot G, Mauffret A. 1984. The western Mediterranean basin geological evolution. Marine Geology 55(3-4): 447-477.

Rey J. 2009. Les Formations Crétacées de l'Algarve Oriental. Comunicações Geológicas 96: 19-38.

Rioux M, Garber J, Bauer A, Bowring S, Searle M, Kelemen P, et al. 2016. Synchronous formation of the metamorphic sole and igneous crust of the Semail ophiolite: New constraints on the tectonic evolution during ophiolite formation from high-precision $\mathrm{U}-\mathrm{Pb}$ zircon geochronology. Earth and Planetary Science Letters 451: 185-195.

Roca E. 1994. La evolución geodinámica de la Cuenca CatalanoBalear y áreas adyacentes desde el Mesozoico hasta la actualidad. Acta Geológica Hispánica 29(1): 3-25.

Rosenbaum G, Lister GS, Duboz C. 2002. Relative motions of Africa, Iberia and Europe during Alpine orogeny. Tectonophysics 359(1): 117-129.

Rossetti F, Goffé B, Monié P, Faccenna C, Vignaroli G. 2004. Alpine orogenic P-T-t-deformation history of the Catena Costiera area and surrounding regions (Calabrian Arc, southern Italy): The nappe edifice of north Calabria revised with insights on the TyrrhenianApennine system formation. Tectonics 23(6).

Rossetti F, Theye T, Lucci F, Bouybaouene ML, Dini A, Gerdes A, et al. 2010. Timing and modes of granite magmatism in the core of the Alboran Domain, Rif chain, northern Morocco: implications for the Alpine evolution of the western Mediterranean. Tectonics 29(2).

Roure F, Addoum B, Malla MS. 2006. Tell-Offshore JIP reports. Rep. 59520, 59521, 59522, 59523.

Roure F, Casero P, Addoum B. 2012. Alpine inversion of the North African margin and delamination of its continental lithosphere. Tectonics 31(3).

Rouvier H. 1977. Géologie de l'Extreme-Nord tunisien : tectoniques et paléogéographies superposées a l'extrémité orientale de la 
chaîne nord-maghrebine. Thèse Doctorat Es Sc, Univ. Pierre et Marie Curie.

Rowley DB, Lottes AL. 1988. Plate-kinematic reconstructions of the North Atlantic and Arctic: Late Jurassic to present. Tectonophysics 155(1): 73-120.

Saadallah A, Caby R. 1996. Alpine extensional detachment tectonics in the Grande Kabylie metamorphic core complex of the Maghrebides (northern Algeria). Tectonophysics 267(1-4): 257 273.

Sahabi M, Aslanian D, Olivet J-L. 2004. Un nouveau point de départ pour l'histoire de l'Atlantique central. Comptes Rendus Geoscience 336(12): 1041-1052.

Sallarès V, Martínez-Loriente S, Prada M, Gràcia E, Ranero C, Gutscher M-A, et al. 2013. Seismic evidence of exhumed mantle rock basement at the Gorringe Bank and the adjacent Horseshoe and Tagus abyssal plains (SW Iberia). Earth and Planetary Science Letters 365: 120-131.

Samaka F. 1999. Apport de la géophysique (sismique réflexion) à l'étude de l'évolution sédimentologique, structurale et paléogéographique des Bassins Supra-nappes du Rif Central. Univ. Mohamed V.

Samaka F, Benyaich A, Dakki M, Hcaine M, Bally AW. 1997. Origin and inversion of the Miocene basins in the Central Rif (Morocco)-Surface and subsurface studies of the Taounate and Tafrannt Basins. Geodinamica Acta 10(1): 30-40.

Sánchez-Gómez M, Azañón JM, García-Dueñas V, Soto JI. 1999. Correlation between metamorphic rocks recovered from Site 976 and the Alpujárride rocks of the western Betics. Proceedings of the Ocean Drilling Program, 161 Scientific Results. DOI: 10.2973/odp. proc.sr.161.225.1999.

Sani F, Zizi M, Bally AW. 2000. The Neogene-Quaternary evolution of the Guercif Basin (Morocco) reconstructed from seismic line interpretation. Marine and Petroleum Geology 17(3): 343-357.

Schaltegger U, Desmurs L, Manatschal G, Müntener O, Meier M, Frank M, et al. 2002. The transition from rifting to sea-floor spreading within a magma-poor rifted margin: field and isotopic constraints. Terra Nova 14(3): 156-162.

Schettino A, Turco E. 2009. Breakup of Pangaea and plate kinematics of the central Atlantic and Atlas regions. Geophysical Journal International 178(2): 1078-1097.

Schmid SM, Kissling E, Diehl T, van Hinsbergen DJJ, Molli G. 2017. Ivrea mantle wedge, arc of the Western Alps, and kinematic evolution of the Alps-Apennines orogenic system. Swiss Journal of Geosciences 110(2): 581-612.

Sdrolias M, Müller RD. 2006. Controls on back-arc basin formation. Geochemistry, Geophysics, Geosystems 7(4).

Septfontaine M. 1983. La formation du jbel Binet (Rif externe oriental, Maroc) : un dépôt «anté-nappes » d'âge miocène supérieur. Implications paléotectoniques. Eclogae Geologicae Helvetiae 76(3): 581-609.

Sherkati S, Letouzey J, Frizon de Lamotte D. 2006. Central Zagros fold-thrust belt (Iran): New insights from seismic data, field observation, and sandbox modeling. Tectonics 25(4).

Sibuet J-C, Rouzo S, Srivastava S. 2012. Plate tectonic reconstructions and paleogeographic maps of the central and North Atlantic oceans. This article is one of a series of papers published in this CJES Special Issue on the theme of Mesozoic-Cenozoic geology of the Scotian Basin. Canadian Journal of Earth Sciences 49(12): 1395-1415.

Simpson GDH. 2006. Modelling interactions between fold-thrust belt deformation, foreland flexure and surface mass transport. Basin Research 18(2): 125-143.
Soussi M. 2000. Le Jurassique de la Tunisie atlasique : stratigraphie, dynamique sédimentaire, paléogéographie et intérêt pétrolier. Univ. Claude Bernard, Lyon-1.

Spakman W, Wortel R. 2004. A tomographic view on western Mediterranean geodynamics. The TRANSMED Atlas, The Mediterranean Region from Crust to Mantle. Berlin, Heidelberg: Springer, pp. 31-52.

Spakman W, Chertova MV, van den Berg A, van Hinsbergen DJJ. 2018. Puzzling features of western Mediterranean tectonics explained by slab dragging. Nature 11: 211-216.

Stampfli GM, Marchant RH. 1997. Geodynamic evolution of the Tethyan margins of the Western Alps. In: Deep structure of the Swiss Alps: results of NRP 20. Boston, Berlin, Birkhäuser: Verlag, pp. 223-239.

Stockmal GS, Beaumont C, Nguyen M, Lee B. 2007. Mechanics of thin-skinned fold-and-thrust belts: Insights from numerical models. Geological Society of America Special Papers 433: 63-98.

Storti F, McClay K. 1995. Influence of syntectonic sedimentation on thrust wedges in analogue models. Geology 23(11): 999-1002.

Suades E. 2016. Estudio integrado tierra-mar en el margen noroccidental de la cuenca de Alborán entre los meridianos 5o 30'wy 3o 30'w. Universidad de Granada.

Suter G. 1980a. Carte géologique du Rif, 1/500.000. Notes Mém Serv Géol Maroc 245a.

Suter G. 1980b. Carte structurale du Rif, 1/500.000. Notes Mém Serv Géol Maroc 245b.

Tejera de Leon J, Boutakiout M, Ammar A, Brahim LA, El Hatimi N. 1995. Les bassins du Rif central (Maroc): marqueurs de chevauchements hors séquence d'âge Miocène terminal au cœur de la chaîne. Bulletin de La Société géologique de France 166(6): 751-761.

Thomas G. 1985. Géodynamique d'un bassin intramontagneux : Le Bassin du Bas-Chelif occidental (Algérie) durant le mio-plioquaternaire. Pau, France: Univ. Pau et Pays de l'Adour.

Thomas MFH, Bodin S, Redfern J, Irving DHB. 2010. A constrained African craton source for the Cenozoic Numidian Flysch: implications for the palaeogeography of the western Mediterranean basin. Earth-Science Reviews 101(1): 1-23.

Thurner S, Palomeras I, Levander A, Carbonell R, Lee C. 2014. Ongoing lithospheric removal in the western Mediterranean: evidence from Ps receiver functions and thermobarometry of Neogene basalts (PICASSO project). Geochemistry, Geophysics, Geosystems 15(4): 1113-1127.

Torbi A, Gélard JP. 1994. Paléocontraintes enregistrées par la microfracturation, depuis l'Hercynien jusqu'à l'Actuel, dans les Monts du Sud-Est d'Oujda (Meseta orientale, Maroc). Comptes Rendus de l'Académie Des Sciences de Paris 318: 131-135.

Tortorici L, Catalano S, Monaco C. 2009. Ophiolite-bearing mélanges in southern Italy. Geological Journal 44(2): 153-166.

Tricart P, Torelli L, Argnani A, Rekhiss F, Zitellini N. 1994. Extensional collapse related to compressional uplift in the Alpine Chain off northern Tunisia (Central Mediterranean). Tectonophysics 238(1-4): 317-329.

van Hinsbergen DJJ, Vissers RLM, Spakman W. 2014. Origin and consequences of western Mediterranean subduction, rollback, and slab segmentation. Tectonics 33: 393-419.

van Wijk J, Axen G, Abera R. 2017. Initiation, evolution and extinction of pull-apart basins: Implications for opening of the Gulf of California. Tectonophysics. DOI: 10.1016/j.tecto.2017.04.019.

Vera JA. 1988. Evolución de los sistemas de depósito en el margen ibérico de la Cordillera Bética. Revista de La Sociedad Geológica de España 1(3-4): 373-391. 
Vera J-A. 2001. Evolution of the South Iberian continental margin. Mémoires Du Muséum National D'histoire Naturelle 186: 109_ 143.

Vergés J, Sàbat F. 1999. Constraints on the Neogene Mediterranean kinematic evolution along a $1000 \mathrm{~km}$ transect from Iberia to Africa. Geological Society, London, Special Publications 156(1): 63-80.

Vergés J, García-Senz J. 2001. Mesozoic evolution and Cainozoic inversion of the Pyrenean rift. Mémoires Du Muséum National D'histoire Naturelle 186: 187-212.

Vergés J, Fernàndez M. 2012. Tethys-Atlantic interaction along the Iberia-Africa plate boundary: The Betic-Rif orogenic system. Tectonophysics 579: 144-172.

Vidal J-C. 1971. Une interprétation nouvelle des nappes du Prérif central (Maroc) et ses conséquences sur la structure de leur substratum autochtone. Comptes Rendus de l'Académie Des Sciences de Paris 272: 24-27.

Vila J-M. 1970. Le Djebel Edough; un massif cristallin externe du Nord-Est de la Berberie. Bulletin de La Société géologique de France 7(5): 805-812.

Vila J-M. 1978. Carte Structurale au 1/500 000 de la chaîne alpine d'Algérie orientale et des confins algéro-tunisiens, publication CNRS BEICIP.

Vila J-M. 1980. La chaîne alpine d'Algérie orientale et des confins algéro-tunisiens. Université Paris-VI, Pierre et Marie Curie.

Vitale-Brovarone A, Beyssac O, Malavieille J, Molli G, Beltrando M, Compagnoni R. 2013. Stacking and metamorphism of continuous segments of subducted lithosphere in a high-pressure wedge: the example of Alpine Corsica (France). Earth-Science Reviews 116: $35-56$.

Watts AB. 2001. Isostasy and Flexure of the Lithosphere. Cambridge, UK: Cambridge University Press.

Wernli R. 1988. Micropaléontologie du Néogène post-nappes du Maroc septentrional et description systématique des foraminifères planctoniques. Notes et Mémoires du Service géologique 331. Rabat, Morocco: Éditions du service géologique du Maroc.
Wildi W. 1983. La chaîne tello-rifaine (Algérie, Maroc, Tunisie) structure, stratigraphie et évolution du Trias au Miocène. Revue de Géographie Physique et de Geologie Dynamique 24(3): 201-297.

Willett SD. 1999. Orogeny and orography: The effects of erosion on the structure of mountain belts. Journal of Geophysical Research: Solid Earth 104(B12): 28957-28981.

Withjack MO, Schlische RW, Olsen PE. 1998. Diachronous rifting, drifting, and inversion on the passive margin of central eastern North America: an analog for other passive margins. $A A P G$ Bulletin 82(5): 817-835.

Yaich C, Durlet C, Renard M. 2000. Corrélation stratigraphique entre les unités oligo-miocènes de Tunisie centrale et le Numidien. Comptes Rendus de l'Académie Des Sciences-Series IIA-Earth and Planetary Science 331(7): 499-506.

Yelles A, Domzig A, Déverchère J, Bracène R, Mercier B, Lépinay D, et al. 2009. Tectonophysics Plio-Quaternary reactivation of the Neogene margin off NW Algiers, Algeria: The Khayr al Din bank. Tectonophysics 475(1): 98-116. DOI: 10.1016/j. tecto.2008.11.030.

Zeck HP. 1999. Alpine plate kinematics in the western Mediterranean: a westward-directed subduction regime followed by slab roll-back and slab detachment. Geological Society, London, Special Publications 156(1): 109-120.

Zitellini N, Torelli L, Brancolini G, Tricart P, Argnani A, Nieto D, et al. 1989. Deep seismic reflection study in the Sicily Channel and Southern Thyrrenian Sea: preliminary results. Gruppo Nazionale di Geofisica della Terra Solida, C.N.R., Convegno Nazionale 8, Roma, pp. 823-882.

Zizi M. 1996a. Triassic-Jurassic extension and Alpine inversion in northern Morocco. Mémoires Du Muséum National D’histoire Naturelle 170: 87-101.

Zizi M. 1996b. Triassic-Jurassic extensional systems and their Neogene reactivation in northern Morocco (the Rides prérifaines and Guercif basin). Rice University.

Cite this article as: Leprêtre R, Frizon de Lamotte D, Combier V, Gimeno-Vives O, Mohn G, Eschard R. 2018. The Tell-Rif orogenic system (Morocco, Algeria, Tunisia) and the structural heritage of the southern Tethys margin, BSGF - Earth Sciences Bulletin 189 : 10. 